\begin{abstract}
This paper considers the protection of universal service in the network industries, with a focus on the postal service and telecommunications sectors. We define the concept of universal service and explain how it was seen as a necessary quid pro quo for securing the liberalisation agenda in the EU. We go on to explain and analyse the two competing means of protecting and compensating universal service, either under the State aid regime or the relevant sectoral legislation. In order to gain a better understanding of how these competing mechanisms operate in practice, we look in detail at two areas where liberalisation and universal service are in particular tension: (i) high-speed broadband and (ii) letter collection and delivery. We conclude by discussing some of the problems of using State aid rules as a substitute for a sectoral framework and contemplate the future of universal service.
\end{abstract}

Keywords: competition law, State aid, Service of General Economic Interest, Universal Service Obligation, telecommunications, postal services, compensation. 


\section{A. Introduction}

Over the last three decades, the EU has been pursuing a liberalisation agenda across all of the network industries - telecommunications, postal services, energy, water and railways. A concern to arise from this is that when traditionally monopolised markets are opened to competition, new entrants may be able to enter and target the most profitable consumers, leaving the incumbent with a disproportionate number of consumers who provide insufficient revenue to cover their costs. This is a particular problem where there have historically been extensive cross-subsidies in favour of groups of consumers who are viewed as vulnerable, deserving or politically sensitive (for example, those living in rural areas). As a consequence, it is often politically difficult or socially undesirable to achieve cost-reflective pricing through tariff rebalancing.

The response in the EU has been to formalise the protection of certain classes of customers through the imposition of universal service obligations (USOs). In the early days of liberalisation, such obligations were normally imposed on the incumbent without it being compensated; its size and the advantages it had derived as the historic monopolist meant that it could afford to absorb these additional costs without being placed at a significant competitive disadvantage. The effectiveness of this approach to universal service begins to unravel where the market share of the incumbent is significantly eroded by new entry, or where new investment is needed in network infrastructure. In the long-run, a sustainable approach to funding universal service has to be found.

In this paper, we consider the legal responses to the protection of the universal service in the EU. In section B, we define what is meant by USOs, and explain some of the potential market distortions that can occur in pursuing them, including how entrants and incumbents may be placed at a competitive (dis)advantage. While there are inherent tensions in attempting to secure universal service alongside liberalisation, a number of EU Member States would never have accepted the latter goal without some formal protection for the former. However, in more recent years, the policy emphasis has shifted towards the introduction of contestability into the provision of universal service with an attempt to reverse the de facto presumption of the incumbent's continuation of the role. In section C, we explain and compare the legal frameworks 
for universal service provision. In the network industries, the relevant EU secondary legislation often prescribes both the requirements of USOs and the means by which compensation may be made to those entrusted with its provision. Alternatively, as a subset of Services of General Interest (SGEIs), Member States may instead choose to make compensation payments to universal service providers (USPs) under the State aid regime, as reformed by the 2012 SGEI package. As we explain, in recent years, under both the sectoral and State aid regimes, increased emphasis has been placed upon contestability in the provision of universal service. In section D, we have selected two contrasting areas to investigate further. The first relates to the provision of high-speed broadband, the expansion of which requires substantial investment in infrastructure, both public and private. What is particularly striking here is that Member States have eschewed the secondary legislation, and the sectoral rules on compensation which it contains, in favour of making use of the State aid regime. The second area is postal services, in particular the collection and delivery of letters. The provision of universal service has come under particular strain in recent years due to increased liberalisation and dramatic falls in demand. Nevertheless, we see here very little use of compensation mechanisms, either under the sectoral or State aid regimes, with a focus instead on incumbents achieving efficiency gains. In section E, we conclude, contemplating the future of universal service, its sustainability, and the extent to which it is subordinated to pro-competition goals.

\section{B. Universal service obligations and liberalisation}

In this section, we first define what is meant by universal service, before proceeding to explain some of the tensions that exist between its protection and the promotion of liberalisation and competition in the network industries. We discuss how the protection of universal service in the EU was essentially a political compromise by Member States in accepting the EU's liberalisation agenda for the network industries. We then explain how universal service can be secured, particularly by utilising the various options that exist in the design of compensation mechanisms. 
The nature and extent of USOs differ significantly between sectors and countries. ${ }^{1}$ In some sectors, such as telecommunication and postal services, USOs tend to be highly specified, whereas in others, EU law lays down requirements which are fairly open textured, leaving Member States with a broad degree of discretion. While there is no universal definition of what is meant by the term, it is normally taken to mean a requirement which maximises the ubiquity of a service in terms of coverage and accessibility. ${ }^{2}$ First, there may be an obligation to provide a prescribed level of geographical coverage for a particular type of service. To achieve geographical ubiquity, it may be necessary to use cross-subsidies (for example, from customers in urban areas to those in rural areas). Second, such obligations may require that services are offered at a price which is "affordable". Again, this may involve cross-subsidies between different types of users (for example, between business and domestic customers). Uniform pricing may be used to achieve this goal or a more targeted approach may be used in the form of special tariffs in favour of particular types of disadvantaged consumers ("social tariffs"). What unifies all of these different requirements is the notion that the market would not otherwise serve these areas and/or consumers, or if it did, prices would be charged which would place services beyond the reach of a significant number of consumers. ${ }^{3}$

The imposition of USOs may lead to a number of market distortions. Restrictions on pricing, in particular uniform pricing mechanisms, can create strategic links between market participants which have complex effects; ${ }^{4}$ for instance, the possibility of higher prices for all consumers,

\footnotetext{
${ }^{1}$ For a comprehensive review of the literature see M Harker, A Kreutzmann and C Waddams, "Public service obligations and competition", (2013) CERRE, Final Report, 23-46, http://www.cerre.eu/sites/cerre/files/130318_CERRE_PSOCompetition_Final_0.pdf accessed 3 August 2016. ${ }^{2}$ Colin R Blackman, “Universal service: obligation or opportunity?” (1995) 19 Telecommunications Policy 171, 172.

${ }^{3}$ On social exclusion, see E Szyszczak, The regulation of the state in competitive markets in the EU (Oxford, Hart Publishing, 2007) 243.

${ }^{4}$ F Mirabel, JC Poudou and M Roland, “Universal service obligations: The role of subsidization schemes” (2009) 21 Information Economics and Policy 1, 7.
} 
including the intended beneficiaries of the policy. ${ }^{5}$ The imposition of USOs may also reduce entry, especially if the obligations are imposed on entrants. ${ }^{6}$

One particular problem with USOs is "cherry-picking", i.e., where new entrants target the most profitable consumers, leaving the incumbent with those consumers who provide insufficient revenue to cover their costs. ${ }^{7}$ While this may be sustainable in the short term, as new entrants establish their position on the market, in the long run the incumbent's costs will be forced upwards, meaning it will either be required to increase its prices, or some form of compensation mechanism will have to be employed (for example, an industry compensation scheme). Such mechanisms are not without their own problems and may lead to the over-compensation of the incumbent. ${ }^{8}$ It may also mean that certain classes of customers are left with the incumbent provider, who is perhaps offering an inferior level of service to that which would be available to them in a competitive environment. ${ }^{9}$ This tends to emphasise the importance of analysing the counterfactual, i.e., the market conditions which would prevail absent the USO. Indeed, it may even be the case that the imposition of USOs on the incumbent provider may actually place it at a competitive advantage vis-à-vis new entrants, especially where it is over-compensated for the cost of providing the USO.

From a political perspective, it is often difficult to withdraw USOs, especially where doing so may lead to the erosion of cross-subsidies leading to adverse distributional consequences. ${ }^{10}$

\footnotetext{
${ }^{5}$ Calzada demonstrates that uniform pricing will affect the development of competition enabling the entrant to enter in a limited way, increasing both the incumbent's prices and the profitability of both players, J Calzada "Universal service obligations in the postal sector: The relationship between quality and coverage" (2009) 21 Information Economics and Policy 10, 18; Hviid and Waddams Price show how non-discrimination clauses imposed in the UK energy markets result in higher prices for all consumers, M Hviid and C Waddams Price, "Non-Discrimination Clauses in the Retail Energy Sector" (2012) 122 The Economic Journal, F236.

${ }^{6}$ S Hoernig and TE Pinto, "Universal Service Obligations: Should they be imposed on entrants?" (2001) ftp://193.196.11.222/pub/zew-docs/div/IKT/hoernig.pdf accessed 3 August 2016.

${ }^{7}$ L Rapp, "Public service or universal service?" (1996) 20 Telecommunications Policy 391, 394; G Simmonds, "Consumer Representation in Europe Policy and Practice for Utilities and Network Industries, Universal and Public Service Obligations in Europe" (2003) CRI Research Report 15/2003, 8. http://www.bath.ac.uk/management/cri/pubpdf/Research_Reports/15_Simmonds.pdf accessed 3 August 2016. ${ }^{8}$ A Gautier and X Wauthy, "Competitively neutral universal service obligations" (2012) 24 Information Economics and Policy 254, 259-60.

${ }^{9}$ JC Panzar, "A methodology for measuring the costs of universal service obligations" (2000) 12 Information Economics and Policy 211.

${ }^{10}$ See OECD, "Rethinking Universal Service for a Next Generation Network Environment" (2006) OECD Digital Economy Papers 113, 22-23, http://dx.doi.org/10.1787/231528858833 accessed 3 August 2016.
} 
Tariff rebalancing may be perceived as inequitable where it leads to higher prices for lower income and rural consumers, and may even result in some consumers disconnecting from the network altogether. ${ }^{11}$ The political sensitivity of tariff rebalancing may be employed by incumbents to resist liberalisation, or to slow its pace, and there is certainly evidence from the past that incumbents have used its spectre as a means of resisting liberalisation. ${ }^{12}$

While there are obvious tensions between liberalisation and USOs, it may be that there is a more nuanced relationship between the two. First, the formal recognition of USOs was seen as a quid pro quo for further liberalisation, especially for Member States like France that have a strong tradition of public service in utilities. ${ }^{13}$ In this context then, USOs may be characterised as a "means to protect the weakest citizens from market liberalization". ${ }^{14}$ So without the strengthening of USOs in law, the achievement of liberalisation policies at the EU level would have been more difficult. Second, liberalisation and USOs may serve the same ends. Increased competition may lead to lower prices, greater efficiency and increased affordability. Furthermore, the formal legal status and specification given to USOs, while differing significantly between sectors, may lead to more meaningful (and enforceable) rights for consumers. ${ }^{15}$ The clearer specification of USOs also increases certainty for market players, including new entrants.

\footnotetext{
${ }^{11}$ Ibid.

12 The UK gas incumbent, British Gas, provided an early example of such lobbying in its evidence to the 1993 Monopolies and Mergers Commission Inquiry into opening the market. They predicted huge increases in fixed charges, less than a decade before they themselves abolished them in the competitive market, see M Bennett, D Cooke and C Waddams Price, "Left out in the cold? New energy tariffs, low-income households and the fuel poor" (2005) 23 Fiscal Studies 167.

${ }^{13}$ T Prosser, The limits of competition law: Markets and public services (Oxford, Oxford University Press, 2005), 106-13. For a comparative discussion, see KA Eliassen and J From, "Deregulation, privatisation and public service delivery: Universal service in telecommunications in Europe" (2009) 27 Policy and Society 239.

${ }^{14}$ M Finger and D Finon, "From "service public" to universal service: the case of the European Union" in M Finger and RW Künneke (eds), International handbook of network industries: The liberalization of infrastructure (Cheltenham, Edward Elgar Publishing Limited, 2011), 55.

${ }^{15}$ W Sauter, "Services of general economic interest and universal service in EU law" (2008) 33 European Law Review 167, 178.
} 
There are potential downsides to greater specification of USOs. ${ }^{16}$ The concept of universal service is a dynamic one, which needs to adapt to changing societal and technological needs. ${ }^{17}$ Issues of particular concern include affordability in the light of changing living standards, changing perceptions of what is an essential service (for example, access to the internet is increasingly perceived as a basic need), and the danger of locking in services which are no longer used extensively nor judged as essential. So where USOs remain static and highly specified, they may become outmoded or irrelevant. ${ }^{18}$

While some form of compensation may be necessary in order to achieve USOs, there are a number of different models which can be chosen, and the incumbent firm is not necessarily the best candidate for discharging the USO. One option is to remove the subsidies from the competitive retail supply market and deliver them through other means, for example, via a monopoly distribution network (where one exists). This occurs in many distribution networks where rural consumers are subsidised by urban consumers by the charging of uniform distribution prices. A second option is to grant special or exclusive rights over certain markets to the universal service provider, preserving its ability to cross-subsidise between profitable and non-profitable customers. This was the model used until recently in postal services. A third option, which tends to be the default regulatory choice, is to allow the incumbent to carry the costs without compensation because it enjoys other advantages. In the long run, as liberalisation gathers pace, it is unlikely that failing to compensate the incumbent will be sustainable. This then raises the vexed question of how to calculate the net costs and benefits for the purpose of

\footnotetext{
${ }^{16}$ The actual level of specification differs significantly between sectors. For post and telecommunications, there is more detailed specification of the universal service requirements in EU law than is the case for the other network industries, in particular, transport, water and electricity. This can, in part, be attributed to the structural characteristics of the different network industries (for example, the amount of cross-border trade); and in part to the historical traditions in the Member States with regard to the definition and implementation of universal and public service provisions in these sectors. See Simmonds, supra n 7, 61; Prosser supra n 13, 174-206; and for a full survey, see Harker et al., supra n 1, 65-73.

${ }^{17}$ J Alleman, P Rappoport and A Banerjee, “Universal service: A new definition?” (2010) 34 Telecommunications Policy 86, 90; J Davies and E Szyszczak, "Universal Service Obligations: Fulfilling New Generations of Services of Economic Interest", in E Szyszczak (ed), Developments in Services of General Interest (The Hague, T.M.C. Asser Press, 2011) 162-71; A Kreutzmann-Gallasch et al, "Criteria to define essential telecoms services" (2013) A Report for Ofcom by the ESRC Centre for Competition Policy, 9-16.

${ }^{18}$ Kreutzmann-Gallasch et al, supra n 17; Harker et al, "Competition for UK postal sector and the universal service obligation" (2014) BIS Consultation response from the ESRC Centre for Competition Policy, http://competitionpolicy.ac.uk/documents/8158338/8261737/CCP+Response+-+BIS++Competition+for+UK+Postal+Sector.pdf/364e21b3-6296-4ee9-8e4d-945b696e8235 accessed 3 August 2016.
} 
compensating the universal service provider. ${ }^{19}$ There are two possible sources of compensation. One is an industry compensation scheme whereby entrants compensate the incumbent for fulfilling the relevant USO. Another is compensation directly from public funds. In either case, there is the problem that the incumbent will be over-compensated because, as with regulation more generally, it enjoys an informational advantage over, and an incentive to exaggerate, its costs. In addition, the incumbent may enjoy certain other intangible benefits in being appointed as universal service provider, for example, brand ubiquity.

There is no reason, however, why the incumbent should be the universal service provider. An auction could be held for supplying consumers who require enhanced services or who are lossmaking, inviting bids to supply them with a subsidy. This is similar to the franchising arrangements for loss making transport routes, and has the obvious advantage of potentially revealing the most efficient provider. Another option is to require all suppliers to either 'pay or play', so that either they supply a particular portion of the loss making consumers, or pay a contribution (in proportion to their market share) into a central fund which is then distributed to those who do. ${ }^{20}$ As we discuss in the remainder of this paper, substantial efforts have been made in recent years to expand the provision of universal service beyond the historic incumbents, albeit with varying degrees of success.

\section{The funding of universal service in a changing environment}

In this section we explain the legal frameworks which govern the compensation of universal service. First, since USOs are generally accommodated within the Treaty - as a subset of SGEI -

\footnotetext{
${ }^{19}$ A paper by Rodriguez and Storer pays considerable attention to the calculation of USOs. Two main approaches are suggested: the net avoided cost and the entry pricing approach, but both have their difficulties. F Rodriguez and D Storer, "Alternative approaches to estimating the cost of the USO in posts" (2000) Information Economics and Policy 285. In a later report on telecoms, the OECD reports on the difficulties in estimating the net cost of providing universal service, including identification of the intangible benefits which might accrue to the universal service provider, and the adverse effect such uncertainty might have on investment in the sector: OECD, supra $\mathrm{n} 10,18$.

${ }^{20}$ For a discussion see P Choné, L Flochel and A Perrot, "Universal service obligations and competition" (2000) 12 Information Economics and Policy 249. The OECD is of the view that such processes can "generate incentives to contain costs, innovate, and reveal the true cost of delivering universal service thus minimising the subsidy required" (OECD, supra n 10, 5). It points to some success in competitive tendering in Chile and Peru, although less success in Australia and Switzerland (where trials resulted in no competitive entry) (OECD, supra n 10, 18).
} 
compensation for the costs generated by them may be justified, even if this requires a derogation from the EU competition rules, including the State aid rules. ${ }^{21}$ We therefore sketch briefly the main principles and requirements for compliance with the State aid rules. Second, the general rules on State aids and SGEIs have, to a certain extent, been displaced by the rules contained in the EU secondary legislation which both define universal service goals and lay down the procedural and substantive provisions for compensation. While these sectoral rules have been in place for a number of years, they have been left largely inactive by Member States due to the incumbents' ability to maintain cross-subsidies without explicit compensation. Indeed, as we explain, the compensation provisions are only triggered if and when the USP can demonstrate that the USO imposes upon it an 'unfair burden', which is by no means straightforward. In recent years the Commission has used its enforcement powers in numerous instances, especially where compensation mechanisms appear to be over-compensating the incumbent, or are designed in such a way as to exclude entrants from being designated as a USP.

\section{State aid, universal service, and Services of General Economic Interest}

While no explicit mention is afforded to universal service in the Treaty on the Functioning of the European Union (TFEU), ${ }^{22}$ the concept is generally considered to fall within the scope of SGEI, which are given specific protection under the TFEU, primarily under Article 106(2). ${ }^{23}$

\footnotetext{
${ }^{21}$ Indeed, in theory, where compensation exists which does not exceed the net cost of providing the USOs, undertaking(s) charged with their fulfilment are not placed at a competitive advantage, and so the State aid rules are not engaged at all.

${ }^{22}$ Consolidated Version of the Treaty on the Functioning of the European Union [2012] OJ C 326/47. Unless indicated otherwise, all further references are made to the TFEU.

${ }^{23}$ SGEIs are also given protection under Article 14 TFEU, Protocol 26 to the TFEU and Article 36 of the Charter of Fundamental Rights. On the effects of Article 14, Protocol 26, and Art 36 of the Charter of Fundamental Rights: Sauter argues that these provisions add substantively little to Article 106(2), see W Sauter, supra n 15, 174; W Sauter, Public services in EU law (Cambridge, Cambridge University Press, 2015) 12. For a general discussion see N Fiedziuk, "Services of general economic interest and the Treaty of Lisbon: opening doors to a whole new approach or maintaining the "status quo"' (2011) 37 European Law Review 226. On the other hand, von Danwitz argues that their adoption is "the culmination point in the fight for a specific legal status for public services" (T von Danwitz, "The Concept of State Aid in Liberalised Sectors", (2008) EUI Working Papers LAW 2008/28, 1 http://cadmus.eui.eu/bitstream/handle/1814/9588/LAW_2008_28.pdf?sequence=1 accessed 3 August 2016).
} 
Notwithstanding the various attempts by the Commission to define SGEI ${ }^{24}$ (and USOs), ${ }^{25}$ Member States have a measure of discretion in defining a service as a SGEI. ${ }^{26}$ This approach allows Member States to establish, extend and adjust the provision of particular services to specific national needs, subject to certain limiting principles developed by the EU courts. That said, in recent years the Court has held that services can only be categorised as a SGEI if it can be demonstrated that the service would not otherwise be provided through the market - the 'market failure' requirement - which significantly limits the apparently broad discretion of Member States. ${ }^{27}$ For example, in a recent case concerning high-speed broadband, the General Court confirmed that the presence of market failure is a necessary condition for a SGEI. ${ }^{28}$

Although external financing may be necessary to secure the provision of USOs, it can also distort competition. Article 106(2) contains a derogation from the application of the competition rules, including the general prohibition on State aids. However, where the payment made to a universal service provider goes no further than merely compensating the undertaking for the net costs of fulfilling the USO, there is in principle no market distortion, since it is not placed at a competitive advantage vis-à-vis its competitors.

In the past there was no clear understanding of whether payments for the provision of SGEIs were to be regarded merely as compensation for discharging those services (the "compensation

\footnotetext{
${ }^{24}$ The term 'SGEI' also lacks a clear definition. However, the European Commission has sought to clarify and define the concept of SGEI in several of its policy documents, for example, as "economic activities which deliver outcomes in the overall public good that would not be supplied (or would be supplied under different conditions in terms of quality, safety, affordability, equal treatment or universal access) by the market without public intervention". European Commission, "A Quality Framework for Services of General Interest in Europe”, (Communication) COM (2011) 900 final, 5.

${ }^{25}$ In the 2011 Communication, the Commission referred to USOs as: "requirements designed to ensure that certain services are made available to all consumers and users in a Member State, regardless of their geographical location, at a specified quality and, taking account of specific national circumstances, at an affordable price". Ibid, 4 . This definition is in line with Article 3(1) of Directive 2002/22/EC (Universal Service Directive) [2002] OJ L108. ${ }^{26}$ The Treaty allows Member States and their local, regional and national public authorities broad discretion to define a service as being SGEI (and USO). Case T-17/02 Olsen v Commission [2005] ECR II-2031, para 216 (confirmed by order of the Case C-320/05P Olsen $v$ Commission [2007] I-131 ECR).

${ }^{27}$ Whether or not a service is provided through the market is then addressed by the test for "manifest error of assessment", Olsen v Commission, supra n 26, para 166. For a defence of this position see Sauter, supra n 15, 178.

${ }^{28}$ In the Colt case, the existence of market failure was assumed when the Member State can demonstrate that the service will not be provided by the market within the near future, Case T-79/10 Colt Télécommunications France v European Commission ECLI:EU:T:2013:463, para 153. Earlier, the General Court ruled in BUPA that in order to pass this test, a SGEI must have a "universal and compulsory nature" and the Member State is obliged to explain why a particular service is to be regarded as SGEI, Case T-289/03 BUPA [2008] II-81 ECR, para 172.
} 
approach"), or as State aid (the "State aid approach"). Under the State aid approach, each payment to an entrusted undertaking was considered as State aid within the meaning of Article 107(1) and, therefore, incompatible with the internal market unless they satisfied one of the public interest exceptions contained in Article 107(2-3). However, even if the compensation in question did not satisfy the State aid exceptions, it could still be justified under Article 106(2). Even though the payment may ultimately be compatible with the internal market, the Commission must be notified of it in advance and the Member State is required to wait for the Commission's approval before making the payment (the standstill obligation). ${ }^{29}$ In contrast, under the compensation approach, payment for the pure recovery of the undertaking's net costs (including a reasonable profit) for the delivery of a SGEI is to be regarded as merely compensatory and not as State aid. Such a payment would be compatible with the internal market without recourse to the public interest exceptions nor the derogation under Article 106(2). Further, as it is not regarded as State aid, a prior assessment by the Commission is not necessary. ${ }^{30}$ In practice, therefore, the main difference between the two approaches is the notification requirement and standstill obligation under the State aid approach, which obviously gives the Commission more control over Member States' autonomy.

In terms of the jurisprudence, it is fair to say that, while the EU courts have not been entirely consistent, the compensation approach dominates. ${ }^{31}$ The issue was apparently settled in the Altmark case, ${ }^{32}$ where the Court confirmed that the compensation approach was the correct one to be followed, confirming as a point of principle that provided the undertaking does not receive over-compensation for the fulfilling its public service mission, such payments do not put it at a competitive advantage within the meaning of Article 107(1). ${ }^{33}$ The Court went further, however,

\footnotetext{
${ }^{29}$ Art 108(3).

${ }^{30}$ L Hancher and P Larouche, "The Coming Age of EU Regulation of Network Industries and Services of General Economic Interest" in PP Craig and G de Búrca (eds), The evolution of EU law (Oxford, Oxford University Press, 2nd edn, 2011) 759; A Jones and B Sufrin, EU competition law (Oxford, Oxford University Press, 5th edn, 2014), chapter State aid, 67-8; For a detailed discussion of the compensation approach and the state aid approach, see Szyszczak, supra n 3, 222-28.

${ }^{31}$ For examples of the compensation approach, see: Case C-240/83 Procureur de la République v ADBHU [1985] ECR 531, para 18; Case C-53/00 Ferring [2001] ECR I-9067, para 27. For examples of the State aid approach, see: Case C-387/92 Banco Exterior de Espana SA v Ayuntamiento de Valencia [1994] ECR I-877, paras 20-22.; Case T106/95 FFSA and Others v Commission [1997] ECR II-229, para 172; Case T-46/97 SIC v Commission [2000] ECR II-2125, para 84.

${ }^{32}$ Case C-280/00 Altmark Trans [2003] ECR I-7747.

${ }^{33}$ Ibid, para 92.
} 
by developing four cumulative criteria which have to be met for a payment to fall outside of the scope of Article 107(1) (“the Altmark criteria”). ${ }^{34}$ Despite the apparent clarity of the Court's criteria, their application has not been unproblematic. The fourth criterion - requiring that the undertaking is either selected by a public procurement process or that compensation should reflect the costs of a "typical, well-run undertaking" (hereafter "the efficiency benchmark") - has been very difficult to apply in practice. ${ }^{35}$ However, in BUPA, this requirement was relaxed by the General Court. Depending on the established compensation scheme in place, an efficiency benchmark may not be needed, even in cases in which the undertaking was not entrusted by an act of public procurement. ${ }^{36}$ Furthermore, in the Deutsche Post case, ${ }^{37}$ the General Court set aside the Commission's State aid decision principally on the ground that it had failed to assess sufficiently whether the payments received by Deutsche Post amounted to over-compensation (as it was required to do in applying the third Altmark criteria). ${ }^{38}$ The decision of the General Court was upheld by the Court, ${ }^{39}$ and the case is seen as an important confirmation of the Altmark criteria and the "compensatory approach" which underpins it. ${ }^{40}$

\footnotetext{
${ }^{34}$ The criteria can be summarised as follows: First, the recipient undertaking must actually have "public service obligations" to discharge, and the obligations must be clearly defined. Second, the method by which the compensation is calculated must be established in advance in an objective and transparent manner. Third, the compensation cannot exceed what is necessary to recover costs incurred. Fourth, the undertaking discharging the public service must either be chosen by a public procurement procedure or the level of compensation should reflect the cost of a "typical, well-run undertaking", ibid, paras 88-94.

${ }^{35}$ Hancher and Larouche, supra n 30, 761 - 2; See also M Klasse, "The Impact of Altmark: The European Commission Case Law Responses" in E Szyszczak and JW van de Gronden (eds), Financing Services of General Economic Interest (The Hague, T. M. C. Asser Press, 2013) 36-7; EAGCP, "Services of General Economic Interest" (2006) Opinion prepared by the State aid Group of EAGCP, http://ec.europa.eu/competition/state_aid/studies_reports/sgei.pdf accessed 3 August 2016.

${ }^{36}$ BUPA, supra n 28, paras 245-8. However, the Commission is still required to examine whether the compensation does not result from any inefficiencies of the service provider (ibid, para 249.). See NA Matos, "The Role of the BUPA Judgement in the Legal Framework for Services of General Economic Interest" (2011) 16 Tilburg Law Review 83, 86-9. In the Chronopost judgment, three weeks prior to Altmark, the ECJ decided that in markets where there is no undertaking to compare the incumbent's costs with, compensation cannot be based on market conditions but rather must "be assessed by reference to the objective and verifiable elements which are available" (Joined Cases C-83/01P, C-93/01P; C-94/01P Chronopost [2003] ECR I-6993, paras 38-40).

${ }^{37}$ Case T-266/02 European Commission v Deutsche Post AG and others ECLI:EU:T:2008:235.

${ }^{38}$ In particular, the Commission had failed to assess whether or not the total costs of delivering the door-to-door parcel service at a uniform tariff exceeded the level of subsidy it received.

${ }^{39}$ C-399/08 European Commission v Deutsche Post AG and others ECLI:EU:C:2010:481. See DC Bauer and G Muntean, "Case Note on European Commission v Deutsche Post AG et al." (2011) 4 European State Aid Law Quarterly 655; A Bartosch, "Clarification or Confusion? How to Reconcile the ECJ"s Rulings in Altmark and Chronopost”, (2003) European State Aid Law Quarterly 375.

${ }^{40}$ Bauer and Muntean, ibid, 669.
} 
In terms of the decisional practice of the Commission, the Altmark criteria has been applied strictly and in the majority of cases the fourth criterion is not met. ${ }^{41}$ The consequence, therefore, is that most payments are considered as State aid (within the scope of Article 107(1)), subject to the Commission's control, the prior notification requirement and the standstill obligation. ${ }^{42}$ However, even where compensation cannot be justified under Article 107(2) or (3), it may still be subject to the derogation under Article 106(2). According to the Court, Article 106(2) has three requirements: the SGEI must be clearly-defined; it must be provided by an "explicitly entrusted" undertaking; ${ }^{43}$ and "the exemption... must not affect the development of trade to an extent that would be contrary to the interests of the Community". ${ }^{44}$ In contrast with Altmark, neither a tendering procedure nor the application of an efficiency benchmark is required. ${ }^{45}$

Following the Altmark judgment, in 2005 the Commission issued guidelines on granting State aids in the form of public service compensation. ${ }^{46}$ These were replaced by a new SGEI Package in 2012, consisting of revised Decision and Framework documents, in addition to a new Communication document. ${ }^{47}$ The objective of the 2012 package is to provide guidance and

\footnotetext{
${ }^{41}$ See Matos, supra n 36.

${ }^{42}$ Klasse, supra n 35, 50.

${ }^{43}$ An entrusted undertaking is any entity engaged in an economic activity, regardless of their legal status and the way in which the entity is financed (see e.g. Case C-41/90 Höfner and Elser v Macrotron [1991] ECR I-1979, para 21 and Joined Cases C-180/98 to C-184/98 Pavlov and Others [2000] ECR I-6451, para 74. Entrustment requires that the undertaking must discharge a public service assigned by an act of a public authority. See Case C-127/73 BRT v SABAM [1974] ECR-313, para 20.

${ }^{44}$ Case T-442/03 SIC v Commission [2008] ECR II-1161, para 144; Joined Cases T-204/97 and T-270/97 EPAC v Commission [2000] ECR II-2267, paras 125-6; Case C-179/00 Merci Convenzionali Porto di Genova [1991] ECR5889, para 26.

${ }^{45}$ SIC v Commission, supra n 44, para 145; Olsen v Commission, supra n 26, para 239. In the CBI case, the General Court confirmed that Article 106(2) TFEU does not require an efficiency test such as that which is laid down in the fourth Altmark criteria; Case T-137/10 CBI v Commission ECLI:EU:T:2012:584, paras 295-300.

${ }^{46}$ The 2005 SGEI Package - or so-called "Monti/Kroes Package" - consisted of a Decision and a Framework document. Both documents contained conditions under which compensation payments granted to entrusted undertakings with the provision of SGEI are compatible with the internal market "Community framework for State aid in the form of public service compensation" [2005] OJ C 297/4; "Commission Decision of 28 November 2005 on the application of Article 86(2) of the EC Treaty to State aid in the form of public service compensation granted to certain undertakings entrusted with the operation of series of general economic interest" [2005] OJ L 312/67). ${ }^{47}$ Commission, "Communication from the Commission on the application of the European Union State aid rules to compensation granted for the provision of services of general economic interest" [2012] OJ C8/4; Commission Decision (2012/21/EU) of 20 December 2011 on the application of Article 106(2) of the Treaty on the Functioning of the European Union to State aid in the form of public service compensation granted to certain undertakings entrusted with the operation of services of general economic interest [2011] OJ L7/3; Commission, "European Union framework for State aid in the form of public service compensation (2011)" (2012/C 8/03) [2012] OJ C8/15 (2012 SGEI Framework).
} 
clarification to the Member States for the assessment of public financing of SGEI. ${ }^{48}$ The Decision is a de facto block exemption for State aids below certain thresholds. Where the requirements of the Decision are satisfied, the public service compensation constitutes State aid but is considered to be compatible with the internal market and therefore no notification is required. ${ }^{49}$ For cases that fall outside the scope of the SGEI Decision, the compatibility of the payment must be assessed under the SGEI Framework. ${ }^{50}$ Where its criteria are satisfied, the payment still constitutes State aid but it is justified under Article 106(2). ${ }^{51}$

The requirements of the SGEI Framework only partially correspond with Article 106(2) jurisprudence. In line with recent case law, the Commission emphasises the market failure requirement in order to establish a genuine SGEI. ${ }^{52}$ The 2012 Framework also prescribes that the entrustment period is limited to the time necessary to recover the most significant assets, ${ }^{53}$ and prescribes methodologies for calculating the compensation payment. ${ }^{54}$ However, the Framework

\footnotetext{
${ }^{48}$ European Commission, "State aid: Commission adopts new rules on services of general economic interest (SGEI)" (2011), Press Release, IP/11/1579.

${ }^{49}$ For SGEIs in postal services and telecommunications, the compensation threshold was lowered from EUR 30 million to EUR 15 million per annum (Article 2(1)(a) of the Decision (2012/21/EU)). Undertakings providing SGEI have to be entrusted with the provision of the service by the Member State (Article 4). The scope of the Decision is then further limited by a 10 year entrustment period (under certain circumstances, where a longer period is required for the amortisation of the investment cost, this period can be extended) to reduce the negative impact on competition as the entrustment act can create a barrier to entry (Recital 12 and Article 2(2) of the Decision); see A Sinnaeve, "What's New in SGEI in 2012? - An Overview of the Commission's SGEI Package" (2012) 2 European State Aid Law Quarterly 347, 357. To avoid overcompensation of the entrusted service provider, the Decision limits the amount of compensation to the net costs, including a reasonable profit (Article 5(1)), in line with the third Altmark requirement.

${ }^{50}$ Note also the de minimis rules: Commission Regulation (EU) 360/2012 on the application of Articles 107 and 108 of the Treaty on the Functioning of the European Union to de minimis aid granted to undertakings providing services of general economic interest [2012] OJ L114/8.

512012 SGEI Framework, Recital 7. The 2012 SGEI Framework does not apply to SGEI in the land transport or public service broadcasting sectors, nor to providers of SGEI in difficulty; 2012 SGEI Framework, Recital 8 and 9. ${ }^{52}$ With regard to the Member States' discretion to actually judge whether the service is not provided through the market, the Commission's control is limited to the manifest error of assessment, 2012 SGEI Framework, Recital 13. 532012 SGEI Framework, Recital 17. This limitation is new compared to the 2005 SGEI Framework.

${ }^{54}$ The first and preferred method is the so-called "net cost avoided methodology". The second possible method is the "cost allocation methodology". Under the first methodology, the necessary net costs - or the net costs expected to be necessary - shall not exceed the difference between the net costs for discharging the services and the net cost or profits for the same provider without the obligation to provide such services (2012 SGEI Framework, Recital 25). For further guidance, the 2012 SGEI Framework refers in Recital 26 to the Annex IV of the Universal Service Directive (Directive 2002/22/EC) and to Annex I of the First Postal Directive (Directive 97/67/EC). The "cost allocation methodology" uses the difference between the costs and revenues for the calculation of the net costs necessary to provide the obligations (2012 SGEI Framework, Recital 28). For a discussion see D Geradin, "The New SGEI Package" (2012) 3 Journal of European Competition Law \& Practice 1. See generally Rodriguez and Storer, supra n 19.
} 
further mandates compliance with the EU Public Procurement rules, ${ }^{55}$ and also requires Member States to "introduce incentives for the efficient provision of SGEI of a high standard, unless they can duly justify that it is not feasible or appropriate to do so". ${ }^{56}$ These two new requirements potentially reduce the compatibility of State aid measures under Article 106(2). ${ }^{57}$ However, the threshold of these two requirements must be lower than the criteria enumerated by the Court in Altmark, otherwise Article 106(2) would be rendered largely redundant. ${ }^{58}$ Nonetheless, it should be noted that both the requirements of a public procurement procedure and the efficiency test is contrary to established case law on Article 106(2). ${ }^{59}$

\section{The Directives and compensation principles: postal services and telecommunications}

In this section, we turn to the alternative route open to Member States in compensating for the provision of universal service, with a focus on postal services and telecommunications. In these two sectors, relative to the other network industries, ${ }^{60}$ a stronger emphasis was put on the formal protection of universal service in the EU secondary legislation, and the principles and procedures governing compensation are the most developed. ${ }^{61}$ For postal services and telecommunications

\footnotetext{
552012 SGEI Framework, Recital 18-19.

562012 SGEI Framework, Recital 39. For example, Member States can incorporate productive efficiency targets in the entrustment act and the level of compensation then depends on the extent to which the targets have been met, 2012 SGEI Framework, Recital 40 and 41.

${ }^{57}$ One should bear in mind that where an undertaking is entrusted with the provision of SGEI through a procurement procedure or where the level of compensation is based on the costs of a comparable efficient undertaking, the Altmark criteria will be satisfied and the payment will constitute a pure compensation payment and not State aid. In such a case, it would not be necessary to rely on the SGEI Framework.

${ }^{58}$ Rather than being based on a "typical and well-run undertaking" (as in the Altmark test), they must be based on objective and measurable criteria (2012 SGEI Framework, Recital 42). See Sinnaeve (n 49) 360. The General Court confirmed that Article 106(2) TFEU does not require an efficiency test such as laid down in the fourth Altmark criteria in CBI v Commission, supra n 45, paras 295-300.

${ }^{59}$ In comparison with Altmark, a tendering procedure is not required by established European case law SIC $v$ Commission, supra n 44, para 145; Olsen v Commission, supra n 26, para 239. See also Geradin, supra n 54, 6-7; EM Mestmäcker and H Schweitzer, Europäisches Wettbewerbsrecht (München, C.H. Beck, 3rd edn, 2014 ), 8. 60 The different structure of the electricity sector in Member States as well as the different stages of liberalisation may have contributed to the fact that universal service is less defined in electricity, see Prosser, supra n 13, 186, 197, 205.

${ }^{61}$ In contrast, the Directive for electricity (Directive 2009/72/EC) contains more limited provisions on both universal service obligations and on compensation mechanisms. With respect to the former, the Directive requires that Member States ensure that all household customers and - at the discretion of Member States - SMEs shall enjoy universal service, defined as the "right to be supplied with electricity of a specified quality within their territory at reasonable, easily and clearly comparable, transparent and non-discriminatory prices" (Article 3(3)). On financial compensation, the Directive merely states that "financial compensation, other forms of compensation and exclusive rights which a Member State grants for the fulfilment" of any obligations "shall be done in a non-discriminatory and
} 
the relevant rules are contained in the Postal Services Directive (PSD) ${ }^{62}$ and Universal Service Directive (USD) respectively. ${ }^{63}$

\subsection{The scope of universal service in postal services and telecommunications}

As was discussed above, Member States enjoy a measure of discretion when defining SGEI (including USOs). This discretion can be reduced or displaced where USOs are specified by European secondary legislation. ${ }^{64}$ The degree to which discretion can be displaced depends on how precisely services are specified in secondary EU legislation. While Member States may impose USOs which go beyond those specified in the Directives, ${ }^{65}$ they may not use the compensation mechanisms contained within them to compensate service providers for these additional obligations. ${ }^{66}$ If Member States go further and expand the scope of USOs, they are subject to the State aid rules. ${ }^{67}$

For telecommunications, the USD requires that Member States ensure that services included in the scope of universal service are made available to all end-users irrespective of their geographical location at an "affordable price". ${ }^{68}$ In addition, with respect to ensuring the affordability of access, Member States may impose on operators to offer tariffs which depart

transparent way" (Article 3(6)). The 2003 Directive [Directive 2003/54/EC (repealed)] was identical. For a wider discussion see Harker, supra n 1, $52-64$.

${ }^{62}$ Directive 97/67/EC of 15 December 1997 on common rules for the development of the internal market of Community postal services and the improvement of quality of service [1998] OJ L15/14, as amended by Directive 2002/39/EC [2002] OJ L176/21, as amended by Directive 2008/6/EC [2008] OJ/L52/3.

${ }^{63}$ Directive 2002/22/EC of 7 March 2002 on universal service and users' rights relating to electronic communications networks and services (Universal Service Directive) [2002] OJ L108/51, as amended by Directive 2009/136/EC [2009] OJ L337/11.

${ }^{64}$ Case C-206/98 Commission v Belgium [2000] ECR I-3509 para 45.

65 The USOs are defined in the Postal Service Directive, Article 3 Directive 97/67/EC, as amended by Directive 2002/39/EC, as amended by Directive 2008/6/EC and in the Universal Service Directive, Articles 3 - 9 Directive 2002/22/EC, as amended by Directive 2009/136/EC.

66 Directive 2002/22/EC, art 32; Directive 2008/6/EC, Recital 30.

${ }^{67}$ Directive 2008/6/EC, Recital 30. In doing so, Member States' discretion under the State aid regime is subject to a stricter proportionality standard (Sauter, supra n 15, 186-88); see also M Ross, "A healthy approach to services of general economic interest? The BUPA judgment of the Court of First Instance" (2009) 34 European Law Review 127, 136-8; Fiedziuk, supra n 23, 228; Klasse, supra n 35, 50-51.

${ }^{68}$ Directive 2002/22/EC, art 3(1). The relevant services are: access to a publicly available telephone network at a fixed location to a public communications network (Directive 2002/22/EC, as amended by Directive 2009/136/EC, art 4), a directory of users and a directory enquiry service (Directive 2002/22/EC, as amended by Directive 2009/136/EC, art 5), the provision of public pay telephones (Directive 2002/22/EC, as amended by Directive 2009/136/EC, art 6), and special measures for disabled end-users (Directive 2002/22/EC, as amended by Directive 2009/136/EC, art 7). 
from "normal commercial conditions", such as "social tariffs" for those on low-incomes or with "special social needs". ${ }^{69}$ They may also require operators to offer tariffs which include geographical averaging. ${ }^{70}$ In postal services, the universal service obligations include the provision of a sufficient density of post offices and post boxes, the daily delivery and collection of specified mail items, at prices affordable for all users. ${ }^{71}$

\subsection{Securing contestability in the provision of USOs}

In order for firms to be compensated for fulfilling universal service, they must first be designated by the Member State. ${ }^{72}$ While Member States have some discretion when it comes to designation, it is circumscribed by a number of principles, including least market distortion. ${ }^{73}$ The USD and PSD make clear that Member States may designate different undertakings to deliver different elements of universal service and/or to cover different parts of the national territory. ${ }^{74}$ In so doing, Member States are, in both cases, required to abide by the principle of non-discrimination, ${ }^{75}$ and the USD further stipulates that the designation mechanism must not result in any undertaking being "a priori excluded from being designated", ${ }^{76}$ ensuring that new entrant firms are not excluded in practical terms from providing USOs. A specific issue was identified in 2005, which appeared to limit designation to the French telecommunications

\footnotetext{
${ }^{69}$ Directive 2002/22/EC, as amended by Directive 2009/136/EC, art 9(2).

${ }^{70}$ Directive 2002/22/EC, art 9(4).

${ }^{71}$ This includes letters up to 2 kilograms, packages up to 10 kilograms but may be increased up to 20 kilograms, and 20 kilograms for inbound parcels from other Member States and services for registered and insured items at a minimum of five working days per week, Directive 1997/67/EC, as amended by Directive 2008/6/EC, art 3.

${ }^{72}$ Directive 1997/67/EC, as amended by Directive 2008/6/EC, art 4; Directive 2002/22/EC, as amended by Directive 2009/136/EC, art 8. The historical position in postal services is different, as the postal incumbents in Member States retained exclusive rights over reserved services in order to facilitate the cross-subsidisation of universal service (this is explained in more detail in section D.2. below). However, the Third Postal Services Directive required the abolition of these exclusive rights, while at the same time putting in place new requirements for designation (modelled on those contained in the USD).

${ }^{73}$ For telecommunications, the Directive requires that Member States must "determine the most efficient and appropriate approach" which respects the principles of "objectivity, transparency, non-discrimination and proportionality", and "seek to minimise market distortions... whilst safeguarding the public interest", Directive 2002/22/EC, art 3(2). The PSD similarly refers to the requirements of "transparency, non-discrimination, proportionality, transparency and least market distortion”, Directive 97/67/EC, as amended by Directive 2008/136/EC, art 4(2).

${ }^{74}$ Directive 97/67/EC, as amended by Directive 2008/6/EC, art 4; Directive 2008/6/EC, Recital 23; Directive 2002/22/EC, as amended by Directive 2009/136/EC, art 8; Directive 2002/22/EC, Recital 14.

${ }^{75}$ Directive 2002/22/EC, art 8(2); Directive 97/67/EC, as amended by Directive 2008/6/EC, art 4(2).

${ }^{76}$ Directive 2002/22/EC, art 8(2).
} 
incumbent. ${ }^{77}$ This was because designation was limited to undertakings that were able to cover all of the national territory. An infringement procedure was launched, and the Court found that the provision in question, to the extent that it excluded operators who were unable to serve the whole of France, breached the principles contained in the USD. ${ }^{78}$ There are obvious tensions between the objective of cost effectiveness and the no a priori exclusion rule, especially in relation to economies of scale and scope. ${ }^{79}$ It is clear from the approach of the Commission and the Court, however, that the no a priori exclusion rule takes precedence. ${ }^{80}$

Various problems have been identified concerning designation, especially in telecommunications. A number of countries have been slow to put in place legislation for the designation of USPs, much to the chagrin of the Commission. ${ }^{81}$ Despite the principles outlined above, and the increased formalisation by Member States of the designation process in domestic legislation, in practice the incumbents are appointed as USPs in the vast majority of cases in both

\footnotetext{
${ }^{77}$ Commission, "European Electronic Communications Regulation and Markets 2005 (11th Report)", (Staff Working Document) Volume I, SEC(2006) 193, 143. Infringement proceedings were also launched against Finland in 2005. In that case, the relevant legislation appeared to specify that the operator designated as USP would be the company either with significant market power or having the largest market share in the region. The case did not come before the Court (ibid, 269).

${ }^{78}$ Case C-220/07 Commission v France [2008] ECR I-95, paras 32 - 33.

${ }^{79}$ BEREC, "Report on Universal Service - reflections for the future" (2010), 17 http://berec.europa.eu/eng/document_register/subject_matter/berec/reports/187-berec-report-on-universal-servicereflections-for-the-future accessed 3 August 2016.

${ }^{80}$ In another case, which resulted in infringement proceedings against Spain, one firm expressed an interest in providing a directory enquiries service. The Spanish rules excluded from consideration firms who were only interested in offering one unique element of the USOs, and hence the firm was not considered. Despite attempting to justify its approach on the ground of cost-effectiveness, the Commission held that the rules for designation were in breach of the principles of the USD. Letter of formal notice from the European Commission to Spain (27.06.2007), "Designation and financing of universal service"; European Commission, "New round of infringement proceedings under the EU telecom rules: What are the issues?", (2007) MEMO/07/2005; The Commission closed the case after Spain had changed its national legislation, European Commission, "Telecoms: Commission requests information from Spain on new charge on operators; closes infringement case on universal service", Press Release, IP/10/322, 18 March 2010.

${ }^{81}$ Commission, "Progress Report on the Single European Electronic Communications Market (15th Report)", (Staff Working Document) Volume I, SEC(2010) 630 final, 57-58.
} 
telecommunications ${ }^{82}$ and postal services. ${ }^{83}$ This may be the result of a lack of incentives for new entrants to apply for designation, even if the process is open to them, a point made by BEREC:

“...[I]t appears that the number of competitors having the technical and financial standing required for an USP designation is very limited, which adds to what can be described as an inherent reluctance of market players to compete for being designated as bearers of obligations... under the regulatory framework" ${ }^{84}$

For postal services, a recent survey of the USP designation points to a failure of most Member States to consider introducing some element of contestability in universal service provision, using instead "universal service designation to continue some remnant of the former legal privileges of the public postal operators". 85

\subsection{Deciding whether to compensate - "net costs" and "unfair burden"}

The relevant legislation on telecommunications and postal services contain broadly similar principles on the implementation and design of compensation mechanisms. ${ }^{86}$ Before such arrangements may be made, the relevant regulator must be satisfied that the provision of universal service represents an "unfair burden" on the designated undertaking(s) based on a "net

\footnotetext{
${ }^{82}$ At that time, in 2005, it was only in Estonia that a tender process resulted in the designation of a new entrant as USP; in Belgium and the Czech Republic, elements of the service were provided by entrants alongside the incumbent, Commission, "European Electronic Communications Regulation and Markets 2006 (12th Report)", COM(2007), 155 final, 17. According to a 2010 Report, published by the Body of European Regulators for Electronic Communications (BEREC), eight out of 27 BEREC countries used the tender process to designate the universal service provider, BEREC, supra n 79, 30-33.

${ }^{83}$ AK Dieke et al., "Main Developments in the Postal Sector (2010-2013)" (Study for the European Commission, Directorate General for Internal Market and Services) (2013), 137, http://ec.europa.eu/internal_market/post/doc/studies/20130821_wik_md2013-final-report_en.pdf accessed 3 August 2016.

${ }^{84}$ BEREC, supra n 79, 31-32.

${ }^{85}$ Dieke et al., supra n 83, 137. Malta, Sweden and Germany are exceptions. The latter has not designated any operator at all since 2008, Harker et al., supra n 1, 37. In Estonia, Luxemburg, Poland, Romania and Sweden universal service is also provided without relying on a designated USP, European Commission, "Implementation of the EU regulatory framework for electronic communications - 2014" (Commission Staff Working Document) SWD(2014) 249 final, 17.

${ }^{86}$ For postal services, alongside the abolition of the "reserved market", new rules on the compensation mechanism were promulgated in 2008 (Directive 97/67/EC, as amended by Directive 2008/6/EC, art 7(1)), which largely reflect those already in existence for telecommunications that are contained in the Universal Service Directive (Directive 2002/22/EC).
} 
cost" calculation of the provision. ${ }^{87}$ The meaning of "unfair burden" is not elaborated upon in either the USD or PSD.

The calculation of net cost, upon which an assessment of unfair burden depends, is by no means straightforward. ${ }^{88}$ When assessing net costs, account should be had to any "market benefit" or "intangible benefits" which accrue to the USP. ${ }^{89}$ The calculation of attributable costs includes identified services or users which can only be provided or served at a loss or under cost conditions falling outside normal commercial standards. A calculation of the net costs of each aspect of universal service is to made separately in order to avoid any "double counting" of any direct or indirect benefits and costs. Notwithstanding the principles above, both the USD and PSD do not define what is meant by "unfair", and several alternative approaches have been suggested, including: whether the net costs of the USO exceed those costs which would be involved in setting-up a compensation mechanism, the inability of the USP to make a normal economic profit (the requirement for a "reasonable profit" is recognised in the PSD), ${ }^{90}$ or where the profitability of the USP differs significantly from its competitors. ${ }^{91}$

Neither the USD nor the PSD specify or give examples of what is an intangible benefit. Recital 20 of the USD merely states that such benefits should be an "estimate in monetary terms, of the indirect benefits that an undertaking derives by virtue of its position as [a] provider of universal service". In a survey of BEREC members, a number of examples of intangible benefits were

\footnotetext{
${ }^{87}$ Directive 2002/22/EC, art 12(1) in accordance with Annex IV, Part A; Directive 97/67/EC, as amended by Directive 2008/6/EC, art 7(3) in accordance with Annex I, Part B.

${ }^{88} \mathrm{Net}$ costs are defined as the difference between the USP's net costs operating with the universal service obligations and operating without them, Directive 2002/22/EC, Annex IV, Part A; Directive 97/67/EC, as amended by Directive 2008/6/EC, Annex I, Part B.

${ }^{89}$ Directive 2002/22/EC, art 12(1) in accordance with Annex IV, Part A; Directive 97/67/EC, as amended by Directive 2008/6/EC, art 7(3) in accordance with Annex I, Part B.See also Commission, "Assessment Criteria for National Schemes for the Costing and Financing of Universal Service in telecommunications and Guidelines for the member States on Operation of such Schemes", $\mathrm{COM}(96) 608$ final. For a discussion of different methodologies used in postal services to determine whether or not a financial burden is "unfair", see Frontier Economics, "Study on the principles used to calculate the net costs of the postal USO: A Report prepared for the European Commission" (2013), 123-36 http://ec.europa.eu/internal_market/post/doc/studies/2012-net-costs-uso-postal_en.pdf accessed 3 August 2016.

${ }^{90}$ Directive 97/67/EC, as amended by Directive 2008/6/EC, Annex I, Part B. For a discussion see F Boldron et al., "A Dynamic and Endogenous Approach to Financing the USO in a Liberalized Environment", in MA Crew and PR Kleindorfer (eds), Progress in the competitive agenda in the postal and delivery sector (Cheltenham, Edward Elgar, 2009).

${ }^{91}$ Frontier Economics, supra n 89, 123-36.
} 
gathered from national regulatory authorities (NRAs). These included: the benefits of geographical ubiquity, which arises where a customer moves from an area served only by the USP to another area where there are new entrants; the "life-cycle effect" benefit, relating to a customer who it is currently unprofitable to serve who might become profitable in the future; and benefits resulting from brand enhancement and corporate reputation..$^{92}$ As BEREC observes, estimating and quantifying the intangible benefits is likely to "prove extremely difficult" in practice. $^{93}$

Once the net costs have been calculated, and these are judged to be an "unfair burden", the Member States must then decide, upon the request of the designated undertaking(s), how to compensate. This compensation can be drawn directly from public funding, or by sharing the net costs between market participants. ${ }^{94}$ Such a sharing mechanism must be administered by a body independent of the beneficiaries of the scheme, ${ }^{95}$ respecting the principles of transparency, nondiscrimination, and proportionality. ${ }^{96}$ For telecommunications, Member States must also respect the principle of "least market distortion", ${ }^{97}$ and have the discretion to exempt new entrants "which have not yet achieved any significant market presence". 98

The net cost calculation and establishment of an unfair burden appears to be a complicated and time-consuming process in telecommunications. Due to various administrative delays, court proceedings, delays in contributions, or updates of net cost calculation methodologies, compensation schemes have not been widely employed by Member States. ${ }^{99}$

\footnotetext{
${ }^{92}$ BEREC, supra n 79, 35-36. For a similar study in respect of postal services, see Frontier Economics, supra n 89, 109-22.

${ }^{93}$ For some examples of methodologies used by the national regulatory authorities, see BEREC, supra n 79, 36-38.

${ }^{94}$ Directive 97/67/EC, as amended by Directive 2008/6/EC, art 7(3); Directive 2002/22/EC, art 13(1).

${ }^{95}$ Directive 2002/22/EC, art 13(2), which goes on to specify this should be either the NRA or a body supervised by it; Directive 97/67/EC, as amended by Directive 2008/6/EC, art 7(4). The PSD also refers to the requirement of supervision by the NRA in the calculation of net costs, Directive 2008/6/EC, Recital 29.

${ }^{96}$ Directive 97/67/EC, as amended by Directive 2008/6/EC, art 7(5); Directive 2002/22/EC, art 13(3).

${ }^{97}$ Directive 2002/22/EC, Recital 23.

${ }^{98}$ Directive 2002/22/EC, Recital 21.

${ }^{99}$ In 2009, compensation mechanisms were only in place and activated in France, Czech Republic, Italy, Spain, Romania, Latvia and in Belgium for social tariffs only, Commission, supra n 81, 58. As is discussed below, the Belgian compensation mechanism for social tariffs was later challenged by the European Commission.
} 
The most important case on the principles which must be followed by Member States in compensating USPs is Commission v Belgium. ${ }^{100}$ The USO in question related to "social tariffs", i.e., discounts which were available to consumers on low incomes and with special needs. All operators, the incumbent and entrants alike, were required to offer these tariffs to such customers. A compensation scheme was set up whereby payments were made to any operator which carried a disproportionate number of social tariff consumers relative to its market share. Compensation was calculated at a flat-rate for all operators and was automatic - there was no additional need to demonstrate that the number of social tariffs carried by an individual operator imposed an "unfair burden", and the net cost of serving a social tariff customer was assumed to be the same for all operators.

The Court found that the automatic nature of the scheme breached the Directive's requirement that an undertaking had to be found to bear an unfair burden before compensation mechanisms could be put in place. ${ }^{101}$ The Court held that a net cost is not per se an unfair burden:

“... [T] he unfair burden which must be found to exist by the national regulatory authority before any compensation is paid is a burden which, for each undertaking concerned, is excessive in view of the undertaking's ability to bear it, account being taken of all the undertaking's own characteristics, in particular the quality of its equipment, its economic and financial situation and its market share". ${ }^{102}$

For the purposes of this assessment, the NRA had to lay down "general and objective criteria" taking into account the undertaking's characteristics, and must carry out "an individual assessment of the situation of each undertaking concerned". ${ }^{103}$ The Court also held that the assessment of the net cost for the undertaking must also include intangible benefits, in line with

\footnotetext{
${ }^{100}$ Case C-222/08 Commission v Belgium [2010] ECR I-9017. See also Case C-389/08 Base and Others [2010] ECR I-9073, a preliminary reference procedure covering the same ground. See also Case C-384/99 Commission v Belgium [2000] ECR I-633.

${ }^{101}$ Commission v Belgium, ibid, para 58. In Commission v France, a compensation scheme set up to compensate the incumbent was unnecessary given that the incumbent held a near monopoly over the market (Case C-146/00 Commission v France [2001] ECR I-9767, paras 25-30).

${ }^{102}$ Commission v Belgium, ibid, para 49. Emphasis added.

${ }^{103}$ Ibid, para 50.
} 
the requirements of the Directive. ${ }^{104}$ It rejected the Belgium Government's argument that where USOs applied to all operators, the benefits would be the same for all of them. ${ }^{105}$

\section{Conclusions}

As we have demonstrated, the provisions which exist for compensating undertakings for the costs of universal service are complex and cumbersome. This would appear to explain their limited take-up by Member States. This may further explain why, in telecommunications, the ex ante system of compensation has been usurped by the State aid regime, especially in relation to the provision of universal service in broadband services. However, the State aid regime has been significantly reconfigured in recent years to promote contestability in the assignment of public service obligations.

\section{Balancing universal access and liberalisation: case studies in broadband and postal services}

In this section, we analyse recent developments in securing universal service in broadband and the letter collection and delivery markets. It is in these two sectors where we see the most pronounced tensions between the achievement of USOs and liberalisation, albeit for different reasons. In telecommunications we witness the most technological change, and liberalisation is the most advanced. However, for broadband, the regime for securing universal access under the USD has largely been usurped by the use of State aid, with important consequences in terms of the Commission's supervisory powers and the formal protection of USOs. Furthermore, while state support for the rolling-out of significant broadband infrastructure investment may be seen as necessary to secure universal access to vital communications services, this objective is subject to a number of limiting principles which give precedence to securing and maintaining effective competition. For postal services, the model of achieving universal service, as originally envisaged under the EU legislation, was one where the incumbent could sustain cross-subsidies

\footnotetext{
104 Ibid, para 84.

105 Ibid, para 69.
} 
because it had exclusive rights over certain market sectors. These rights were gradually withdrawn, with full competition being introduced across the EU between 2010 and 2012. Alongside this, the rules on compensation were also reformed to the extent that Member States were encouraged to ensure that there was a level of contestability in universal service provision. In the collection and delivery of letters, our focus here, demand has been declining for a number of years, while at the same time incumbents have seen a gradual reduction in their ability to subsidise USOs. In this sector, there is little use of compensation mechanisms, despite the claims that universal service is being placed in jeopardy by new entrants and their so-called 'cherrypicking' of the most profitable consumers. The emphasis thus far has been on the incumbents achieving efficiency gains. ${ }^{106}$

\section{Broadband and its inclusion within the USOs}

There is no doubt that, in a sector such as communications where technological progress and demand conditions evolve rapidly, services which might have been seen as essential until only recently can become obsolete. There is no better example than the provision of public payphones which are only used by a very small percentage of end-users, yet are very expensive to maintain. ${ }^{107}$ It is hardly surprising, therefore, that bringing new services within an EU-wide definition of universal service has be approached with considerable caution by both Member States and the Commission. In some cases, such as mobile services, the answer is straightforward; the market is the best route to maximising both ubiquity and affordability, without the need for any form of state intervention. ${ }^{108}$

The position within broadband is quite different, where it is clear that neither national governments nor the Commission believe that universal broadband coverage will be achieved by

\footnotetext{
106 See, for example, Dieke, supra n 83, 220-22.

107 Some Member States have already withdrawn the obligation to provide public payphones as part of the USO (Belgium, Finland, the Netherlands, Latvia, Cyprus, Denmark, Estonia, Germany, Luxembourg, Poland, Romania and Slovakia), European Commission, "Implementation of the EU regulatory framework for electronic communication - 2015" (Commission Staff Working Document) SWD(2015) 126 final, 22.

${ }^{108}$ European Commission, "Universal service in e-communications: report on the outcome of the public consultation and the third periodic review of the scope in accordance with Article 15 of Directive 2002/22/EC",

(Communication) COM(2011) 795 final, 8-9, 12.
} 
the market alone. ${ }^{109}$ This is particularly the case when it comes super-fast broadband - so-called “next generation access" (NGA) - the rolling-out of which requires substantial upgrading and replacement of existing telecommunications infrastructure. ${ }^{110}$ An obvious solution to this problem would be to use the existing sectoral regime by including a minimum level of broadband services within the definition of USOs, triggering - where appropriate - the use of compensation mechanisms for the investment necessary to secure coverage in areas that would otherwise be unprofitable to serve.

Since the original USD, Member States have been required to ensure that all users connected at a fixed location have access to data communications "at data rates that are sufficient to permit functional internet access, taking into account prevailing technologies used by the majority of subscribers and technological feasibility". ${ }^{111}$ In contrast to the original Directive which specified, for the purposes of imposing a USO, functional internet access as a single narrowband connection at a maximum data rate, ${ }^{112}$ the 2009 amending Directive removed any reference to a defined data rate, ${ }^{113}$ making clear that Member States were to have flexibility in defining a minimum level of internet access, "taking due account of specific circumstances in national markets, for instance the prevailing bandwidth used by the majority of subscribers in that Member State, and technological feasibility, provided that these measures seek to minimise market distortion". ${ }^{114}$ This was a significant change since Member States, while always being free to impose more onerous universal service obligations than those specified in the USD, were not permitted to include these within any compensation mechanism involving specific undertakings. ${ }^{115}$ The situation now allows Member States to include broadband access within the

\footnotetext{
${ }^{109}$ F Chirico and N Gaál, "A Decade of State Aid Control in the Field of Broadband” (2014) 13 European State Aid Law Quarterly 28, 28-29.

${ }^{110}$ For an overview see A Kliemann and O Stehmann, "EU State Aid Control in the Broadband Sector - The 2013 Broadband Guidelines and Recent Case Practice” (2013) 12 European State Aid Law Quarterly 493, 495-7.

111 Directive 2002/22/EC, art 4(2).

112 Ibid, Recital 8. A single narrowband network connection referred to a data rate of $56 \mathrm{kbit} / \mathrm{s}$. Member States were allowed to deviate and lower the data rate where necessary.

113 Directive 2009/136/EC.

114 Ibid, Recital 5.

115 Directive 2002/22/EC, art 32. The wording of this provision was unchanged by the 2009 amending Directive. However, Directive 2009/136/EC, Recital 5 makes clear that where an expansion of minimum internet access covered by USO within a Member State results "in an unfair burden on a designated undertaking, taking due account of the costs and revenues as well as the intangible benefits resulting from the provision of the services concerned, this may be included in any net cost calculation of universal obligations".
} 
scope of USO, with the potential to activate any of the compensation mechanisms specified therein, rather than notifying measures under the State aid framework. ${ }^{116}$ The interesting fact is that they so rarely do so. ${ }^{117}$

\subsection{Compensating investment for universal broadband coverage - USD v State aids regime}

Despite the permissive approach created by the 2009 amending Directive, in its review of universal service in 2011, the Commission encouraged Member States not to include broadband access within their USOs, fearing that doing so could lead to higher prices for consumers, and "could distort markets and put an unreasonable burden on the sector". 118 This message has been largely followed by Member States. ${ }^{119}$

In parallel, however, the EU has developed a proactive policy in favour of encouraging public support and subsidies in favour of increasing both the coverage and quality of broadband access. A key plank of the Europe 2020 strategy, the "Digital Agenda for Europe" (DAE) adopted in 2010, is aimed at accelerating the role-out of high-speed broadband across the EU. ${ }^{120}$

\footnotetext{
${ }^{116}$ Directive 2009/136/EC, Recital 5 makes clear that alternative financing methods may also be enacted. The Commission confirmed that compensation for the infrastructure and wholesale provision of basic broadband in the form of State aid did not breach the original USD, Decision N381/2004 Haut débit en Pyrénées-Atlantiques [2004] Press Release IP/04/1371; Decision N382/2004 Haut débit en Limousin - DORSAL [2005] Press Release IP/05/530. 117 Belgium, Spain, Finland, Croatia, Malta, Sweden and Latvia (only for disabled end-users) have included broadband at different broadband speeds within the scope of universal service. Latvia, Slovenia and the United Kingdom are discussing whether or not to extend the scope of USO by including broadband, European Commission, supra n 107, 22. However, there are reports the European Commission is now proposing to include broadband access in the scope of universal service, C Stupp, "Broadband internet access will become a legal right under new EU telecoms rules”, EurActiv.com, 29 July 2016, http://www.euractiv.com/section/innovationindustry/news/broadband-internet-access-will-become-a-legal-right-under-new-eu-telecoms-rules/?nl_ref=17987440 accessed 3 August 2016.

${ }^{118}$ European Commission, "Universal service in e-communications: report on the outcome of the public consultation and the third periodic review of the scope in accordance with Article 15 of Directive 2002/22/EC", (Communication) COM(2011) 795 final, 12.

${ }^{119}$ Subject to some limited exceptions, it appears that the majority of Member States are pursuing increasing broadband access outside of the sectoral rules, see BEREC, supra n 79, 59.

120 European Commission, “A Digital Agenda for Europe” (Communication) COM(2010) 245 final.
} 
The DAE contains a number of ambitious broadband targets, ${ }^{121}$ the achievement of which will involve considerable investment in infrastructure, both private and public. The key danger of leaving infrastructure investment merely to private firms is that high-speed broadband access will be "concentrated in a few high-density zones with significant entry costs and high prices". ${ }^{122}$ Furthermore, relying only upon the private sector will result in under-investment since the positive externalities resulting from network expansion will not be captured, particularly the economic growth which it can facilitate. Such "market failures" can be corrected somewhat by public sector investment and, for this reason, the DAE seeks to impose on Member States an obligation to draw-up national broadband plans which should include the use of "public financing in line with EU competition and state aid rules”, in particular avoiding market distortions. $^{123}$

In order to complement the general guidelines on State aids (explained in section C.1. above), the Commission has attempted to enunciate in detail the principles it will apply to broadband in a set of Guidelines first issued in 2009, and then subsequently updated in $2013,{ }^{124}$ the latter reflecting the priorities of the DAE, particularly the need for increased public investment in NGA broadband. ${ }^{125}$

The Guidelines recognise, on the one hand, that the DAE targets cannot be achieved without the support of public funds, while cautioning that State aid should only be complementary to, and not a substitute for, the investments of market players, limiting as far as possible the risk of "crowding out of private investments". ${ }^{126}$ It notes the need to go beyond mere market failures; markets may produce outcomes which are efficient but are otherwise "unsatisfactory from a

\footnotetext{
${ }^{121}$ The first of these - securing the availability of basic broadband to all European citizens - was achieved ahead of schedule in 2013. The focus now is how to provide fast and ultra-fast broadband by 2020 to all and half of the European households respectively. European Commission, "100\% basic broadband coverage achieved across Europe - EU target achieved ahead of schedule. Next stop is fast broadband for all." (2013), Press Release, http://europa.eu/rapid/press-release_IP-13-968_en.htm accessed 3 August 2016.

${ }^{122}$ European Commission, supra n 120, 19.

${ }^{123}$ Ibid, 21.

${ }^{124}$ European Commission, "EU Guidelines for the application of State aid rules in relation to the rapid deployment of broadband networks" [2013] OJ C25/1.

${ }^{125}$ The cost of the provision of internet speeds of 30 Mbps are estimated to be nearly EUR 60 billion and to provide at least half of the European households with ultra-fast internet (100 Mbps) may be up to EUR 268 billion, European Commission, supra n 124, para 2.

${ }^{126}$ Ibid, para 4.
} 
cohesion policy point of view" in addressing the digital divide. ${ }^{127}$ An element of market distortion is consistent with this policy, but these effects need to be outweighed by the positive effects of wider access and penetration. ${ }^{128}$

In scrutinising state interventions, principally assessed under Article 107(3), ${ }^{129}$ the Commission applies a series of necessary conditions, including the need to demonstrate that - absent the aid the infrastructure investment would not take place, that the aid is limited to the minimum level necessary to remedy either the market failure or to correct social or regional inequalities that would the market alone would produce. ${ }^{130}$ Overall, it is the incumbent upon the Member State to demonstrate a "step change" in broadband availability before any distortion of competition can be justified by the efficiency or social goals being pursued. Even where aid can be justified, a series of measures to minimise market distortions are required, including consultation with market players who may be planning infrastructure investments in the areas concerned, and the imposition of wholesale access conditions commensurate with the need to avoid the creation of regional service monopolies at the retail level. ${ }^{131}$ Echoing the SGEI Framework, the Guidelines also require that, in selecting the beneficiaries of the aid, there is a competitive selection process in line with EU public procurement principles. ${ }^{132}$ The use of a competitive selection procedure appears to be vital to avoid the "tendency of public authorities to contract with the national telecommunications incumbent". ${ }^{133}$ Failure to comply with the terms of the Guidelines may result in a (costly) requirement to re-run the tender process. ${ }^{134}$

\footnotetext{
127 Ibid, para 5.

128 Ibid, para 6.

${ }^{129}$ In the case of broadband projects, the state aid measures may be compatible with the internal market, if the measure promotes the economic development of areas with an abnormally low standard of living or high unemployment rate (Article 107(3)(a) TFEU) or in which the aid enhances the development of certain economic activities or certain economic areas and does not have a negative effect on the European Union (Article 107(3)(c) TFEU).

${ }^{130}$ European Commission, supra n 124, paras 30-54.

131 Ibid, supra n 124, paras 51, 78; See Kliemann and Stehmann, supra n 110, 512-13.

132 European Commission, supra n 124, para 78(c); Member States are also required to respect the principle of technological neutrality with no a priori preference given to one type of technology over another, European Commission, supra n 124, para 78(e).

133 Kliemann and Stehmann, supra n 110, 511.

${ }^{134}$ F Chirico and N Gaál, "State aid to broadband: primer and best practices" (2011) Competition Policy Newsletter, Number 1, 50, 55 http://ec.europa.eu/competition/publications/cpn/2011_1_10_en.pdf accessed 3 August 2016. Even where this requirement is not met, aid may be lawful under Article 106(2) (see Decision N196/2010 Establishment of a Sustainable Infrastructure Permitting Estonia-wide Broadband Internet Connection (EstWin Project) [2010].
} 
There has been a considerable increase in the number of broadband State aid cases since the first one was notified in 2003. ${ }^{135}$ Between December 2003 and August 2009, the Commission processed only 47 cases, whereas between the adoption of the 2009 Guidelines and mid-February 2014, it decided 85 broadband cases, clearing $82 .{ }^{136}$ In terms of the volume of State aid involved, this increased sharply from an annual average of $€ 30-55$ million in 2003-2005, to almost $€ 2$ billion per year from 2010 and $€ 6$ billion in $2012 .{ }^{137}$

The vast majority of cases appear to be notified and cleared under the State aid regime, but there remains a residual category for cases which may escape the State aid regime altogether because the Member State seeks to rely upon the Altmark criteria. ${ }^{138}$ Such cases are dealt with briefly in the Guidelines. ${ }^{139}$ The most significant case to date is Réseau à très jait débit en Hauts-deSeine. ${ }^{140}$ Here, following a competitive tendering process, the French authorities awarded a subsidy of $€ 59$ million over 25 years to a consortium to build a high-speed broadband network in the Hauts-de-Seine department, an area bordering Paris. Following a voluntary notification by France, the Commission determined that the payment did not constitute State aid, ${ }^{141}$ a decision which was contested by a number of competitors before the General Court. ${ }^{142}$ The Court upheld the Commission's decision that all four Altmark critera were met. The first of these, the existence of a SGEI, was present since there was evidence of a "market failure" in so far as, despite being a relatively densely populated area, there was evidence to suggest that the commercial operators would not have the incentives to serve all users in the area with high-speed broadband. The

\footnotetext{
135 Decision N282/2003 Cumbria Broadband-Project ACCESS [2003].

136 European Commission, "Commission decision on State aid to broadband" (2016) http://ec.europa.eu/competition/sectors/telecommunications/broadband_decisions.pdf accessed 3 August 2016. For a detailed discussion of the cases, see Kliemann and Stehmann, supra n 110.

137 Chirico and Gaál, supra n 109, 30. This amounts to 10 per cent of the total State aid granted (ibid, 31). This actual amount may be higher since the notification requirement does not apply, in theory at least, to investment which meets the Altmark criteria.

138 According to Kliemann and Stehmann, supra n 110, 504 only three cases have been considered by the Commission under Article 106(2), all concerning France. Of course, there are other categories of cases where public investment does not amount to State aid (e.g. where the market investor principle can be demonstrated with respect to the aid, European Commission, supra n 124, paras 16 and 17.

139 European Commission, supra n 124, paras 18-27.

140 Decision $N$ 331/2008 Réseau à très jait débit en Hauts-de-Seine [2009] C(2009) 7426 final.

${ }^{141}$ Strictly speaking, there is no requirement to notify, but it appears that France opted to do so for legal certainty reasons, Kliemann and Stehmann, supra n 110, 504.

142 Case T-79/10 Colt Télécommunications France v Commission ECLI:EU:T:2013:463; Case T-258/10 Orange v Commission ECLI:EU:T:2013:471; Case T-325/10 Iliad and Others v Commission ECLI:EU:T:2013:472.
} 
General Court confirmed that the presence of a market failure, which was an "objective concept", ${ }^{143}$ was a necessary condition for finding a service to fall within the SGEI definition. ${ }^{144}$ It also held that the presence of universal service with respect to basic broadband, did not demonstrate the lack of a market failure on the high-speed broadband market. ${ }^{145}$ The Court also rejected the arguments of the commercial operators that over-compensation would occur, contrary to the third Altmark criterion, merely because the scheme is designed to use crosssubsidies from profitable consumers to reduce the costs of serving those who are unprofitable. ${ }^{146}$

\subsection{Conclusions}

The approach of the European Commission and the majority of the Member States raises the question of why they prefer using State aid procedures instead of including broadband in the scope of universal service under the USD and then, if necessary, compensate the universal service provider.

All Member States have developed national broadband plans for fulfilling the goals of the DAE, some going even further. Some countries focus on improving broadband access in rural areas, while others that have sufficient coverage in all parts of their country may focus on the availability of NGA broadband. ${ }^{147}$ This differentiated approach certainly tells against the adoption of a USO at the EU level with prescribed minimum broadband speeds. On the other hand, the requirement as it now stands in the USD does leave Member States with a considerable amount of discretion when it comes to defining a universal level of broadband access suitable to the relevant markets and demand conditions. Furthermore, for national governments, invoking the provisions of the USD with respect to both prescribing and, where necessary, compensating

\footnotetext{
143 Colt, supra n 142, para 158.

${ }^{144}$ Ibid, para 153. As has been pointed out elsewhere, this is an important development since it limited the discretion member states have to determine whether there is the necessity for a SGEI, E Szyszczak, "Services of General Economic Interest and State Measures Affecting Competition” (2014) 5 Journal of European Competition Law \& Practice, 508, 514.

145 Colt, supra n 142, para 161.

${ }^{146}$ Ibid, paras 185-6. The Court of Justice ruled inadmissible the competitors challenge to the General Court's judgment Case C-621/13P Orange v Commission ECLI:EU:C:2015:114; Case C-624/13P Iliad and Others v Commission ECLI:EU:C:2015:112.

${ }^{147}$ For detailed information on national broadband plans and their realisation, see European Commission, supra $\mathrm{n}$ 120; BEREC, supra n 79.
} 
for universal levels of broadband access does have the advantage of avoiding the Commission's supervisory jurisdiction under Article 108(3). ${ }^{148}$ However, the use of the USD procedures are complex and may give rise to a level of legal uncertainty which itself may result in sub-optimal levels of investment. A USO provider must first be designated, and it will only be compensated where the NRA determines that it bears an unfair burden. As was discussed in section C.2., this does not simply mean net costs; in each case an individual assessment is required and what is an unfair burden for one undertaking may not be for another operator (this assessment depends on the firm's size and market share, its equipment, economic and financial situation, and any intangible benefits of being the USP). ${ }^{149}$ As the rules under the USD derive from the Altmark criteria, the level of compensation is strictly limited to the provision of USO, i.e. the USP can only be compensated for infrastructure investment which could not be supported by the market. ${ }^{150}$ This methodology no doubt creates uncertainty for a potential USP, which is likely to impact disproportionately on new entrant firms who might otherwise be willing to invest in infrastructure, rather than merely relying upon access to the incumbent's network. Indeed, one of the key benefits of relying on the State aid regime is the extent to which it opens avenues for infrastructure competition, especially in relation to the deployment of NGA broadband, which can no longer be supported only by the incumbent's legacy networks. ${ }^{151}$ By way of contrast, a reliance on the incumbent provider is likely to create significant barriers to entry, and merely extend incumbency advantages into new broadband service markets.

\section{Postal services}

The concept of universal service in the postal sector has a long history. Historically, the norm throughout the EU was to have a monopoly postal provider charged with an obligation to fulfil universal service at a uniform price. From the early 1990s, however, this model of universal service delivery was gradually dismantled, with the abolition of exclusive rights for incumbents

\footnotetext{
${ }^{148}$ Interestingly, Chirico and Gaál argue that the principles established in the Guidelines and the underlying case law are now so clear and consistently applied that a State aid exemption for broadband should now be put into place, Chirico and Gaál, supra n 109, 36.

${ }^{149}$ Commission v Belgium, supra n 101.

${ }^{150}$ European Commission, supra n 124, para 26; L Papadias, F Chirico and N Gaál, "The new State Aid Broadband Guidelines: not all black and white" (2009) Competition Policy Newsletter, Number 3, 17, 20 http://ec.europa.eu/competition/publications/cpn/2009_3_3.pdf accessed 3 August 2016.

${ }^{151}$ For a discussion see Kliemann and Stehmann, supra n 110, 498.
} 
from 2012 onwards. Alongside this there has been significant changes in demand, especially a steep decline in the volume of letters, as customers and businesses increasingly use electronic forms of communication. ${ }^{152}$ While new entry in the postal services market may have played a significant role in securing greater efficiency, it has also posed a challenge to the sustainability of universal service. Competition has come from firms who have only entered the most profitable segments of the market, such as bulk mail, business to business communications, and the growing parcel delivery sector. ${ }^{153}$ This poses particular difficulties for incumbents, whose ability to cross-subsidise USOs has been eroded.

\subsection{Liberalisation of postal services and the protection of USOs: reconciling the two objectives}

The liberalisation of postal services began with the publication of a Green Paper in 1992 which proposed to protect and finance USOs by granting exclusive rights to the incumbents with respect to specific reserved services. ${ }^{154}$ This was followed in 1994 by a Council resolution inviting the Commission to come forward with legislative proposals to include a definition of a minimum level of universal service and, in order to ensure "the economic and financial viability" of the provision of universal service, the definition of "a sector of appropriate dimensions which may be reserved for universal service providers". ${ }^{155}$ The First Postal Directive ${ }^{156}$ in 1997 defined universal service as "the permanent provision of a postal service of specified quality at all points in their territory at affordable prices for all users", ${ }^{157}$ prescribing the minimum levels of service

\footnotetext{
${ }^{152}$ In the UK, the volume of letter mail has dropped by $28.2 \%$ since 2008. Despite the loss in volume, the prices for standard-sized letter mail are cheaper than in other European countries, Ofcom, "International Communications Market Report" (2014), $311 \mathrm{http} / / /$ stakeholders.ofcom.org.uk/binaries/research/cmr/cmr14/icmr/ICMR_2014.pdf accessed 3 August 2016. The financial crisis and the recession has left its scars, Dieke et al., supra n 83, 168.

153 The parcel market has grown over the last years (23.4\% between 2008 and 2013), mainly because of an increasing popularity of e-commerce leading to a growth of the business to consumer segment of the parcel market. The revenues in the parcel market are also higher than in the letter market. In 2014, Royal Mail's domestic parcel revenue market share was 31\%, Business, Innovation and Skills Committee, "Competition in the postal services sector and the Universal Service Obligation" (Ninth Report of Session 2014-15), para 56, http://www.publications.parliament.uk/pa/cm201415/cmselect/cmbis/769/769.pdf accessed 3 August 2016.

${ }^{154}$ Commission, "Green Paper on the Development of the Single Market for Postal Services" (Communication) COM(91) 476 final.

${ }^{155}$ Council Resolution of 7 February 1994 on the development of Community postal service [1994] OJ C 48/3.

${ }^{156}$ Directive 97/67/EC.

${ }^{157}$ Ibid, art 3(1).
} 
Member States should seek to protect. ${ }^{158}$ At the same time, it stipulated the limitations of reserved services, and set out a number of deadlines to be met in the gradual reduction of their scope, "taking into account the financial equilibrium of the universal service provider(s)". ${ }^{159}$

In 2002, the Commission reported on the effect of liberalisation of universal service, painting a very positive picture of the situation in all of the Member States. ${ }^{160}$ Not only were the minimum requirements of the Directive being met, in many countries they were being exceeded significantly. Furthermore, while the Directive only required universal service at "affordable prices", ${ }^{161}$ the Commission reported that "the uniform tariff remains a cornerstone of universal service in all Member States (even if not a regulatory requirement in all of them)". ${ }^{162}$ However, there was evidence that the financial stability of USPs was in question: in seven Member States, provisions for compensation mechanisms were in place, although at that time only Spain had plans to activate a fund. ${ }^{163}$ All in all, the Commission concluded that universal service was "not at risk". ${ }^{164}$ This finding was hardly surprising given the report had been overtaken by the adoption of Second Postal Service Directive, ${ }^{165}$ which laid down deadlines for the significant reduction in the scope of reserved services in 2003 and 2006 while at the same time leaving the universal service requirements substantially the same. ${ }^{166}$

Although the clear endpoint was the removal of reserved markets, there was evidence of some nervousness over the sustainability of USOs, the Directive requiring the Commission complete an assessment by the end of 2006 of the "impact on universal service of the full accomplishment of the postal internal market". ${ }^{167}$ In fulfilling that requirement, the Commission announced a

\footnotetext{
${ }^{158}$ Directive 97/67/EC, art 3(3).

159 Ibid, art 7(3).

${ }^{160}$ Commission, "Report from the Commission to the European Parliament and the Council on the application of the Postal Directive (97/67/EC Directive)" COM(2002) 632 final, 16-19.

${ }^{161}$ Directive 97/67/EC, art 3(1).

${ }^{162}$ Commission, supra n 160, 17.

163 Ibid, 18.

${ }^{164}$ Ibid.

165 Directive 2002/39/EC.

${ }^{166}$ Directive 97/67/EC, as amended by Directive 2002/39/EC, art 7(1). The market was opened in four steps. The first reduction of the reserved areas took place in 1999 when the market was opened for items weighing 350 grams or more and costing less than five times the public tariff. The Second Postal Directive reduced the limit for reserved services further to items weighing less than 100 grams as from 1 January 2003 and for services weighing less than 50 grams from 2006 on respectively.

167 Directive 97/67/EC, as amended by Directive 2002/39/EC, art 7(3).
} 
detailed "prospective study" of the implications of full market opening on universal service. ${ }^{168}$ Published in 2006, the study had one core message: that market opening should not be delayed beyond 2009. ${ }^{169}$ Those countries which had already introduced significant postal competition Sweden, Finland and the UK - had not seen a decline in the attainment or quality of USOs, and there was evidence of increased efficiency and reliability of postal services in those countries. ${ }^{170}$ Indeed, the Commission opined, one of the key problems in delaying full market opening would be the resulting lack of incentives operating on the incumbents to increase their efficiency and preparedness for fully fledged competition. Overall, the Commission's premise was that competition would enhance service quality, with universal service benefiting from the "dynamic efficiencies" that would be created. ${ }^{171}$ Only once this was achieved would further interventions be required to protect USOs. These would be regulatory safeguards, in the form of service standards or price caps and, only in the last resort, specific subsidies for USPs. ${ }^{172}$

The key recommendation of the Commission's study was implemented with the adoption in 2008 of the Third Postal Directive. ${ }^{173}$ All postal markets had to be fully opened to competition by the end of 2010, although eleven Member States took advantage of a two year transitional period. ${ }^{174}$

Despite the removal of the reserved areas, the scope of universal postal service has been retained substantially at the levels originally laid down in the First Postal Services Directive. ${ }^{175}$ Member States do retain a degree of discretion and flexibility to meet national demands and circumstances. ${ }^{176}$ While the first two Directives clearly envisaged the incumbent as the de facto universal service provider, alongside the removal of the reserved areas, the Third Postal

\footnotetext{
168 Commission, "Report from the Commission to the European Parliament and the Council on the application of the Postal Directive (97/67/EC Directive as amended by Directive 2002/39/EC)" COM(2005) 102 final, 7.

${ }^{169}$ Commission, "Prospective study on the impact on universal service of the full accomplishment of the postal internal market in 2009” (Report) COM(2006) 596 final.

${ }^{170}$ Commission, supra n 169, 4.

171 Ibid, 7.

172 Ibid.

173 Directive 2008/6/EC.

${ }^{174}$ Ibid, art 2(1) and art 3(1); Those Member States were Czech Republic, Greece, Cyprus, Latvia, Lithuania, Luxembourg, Hungary, Malta, Poland, Romania, and Slovakia.

175 Directive 97/67/EC, as amended by Directive 2002/39/EC, as amended by Directive 2008/6/EC, art 3.

176 Directive 2008/6/EC, Recital 23.
} 
Directive gives the Member States more freedom to designate one or more universal service provider(s), or to rely on the market when intervention is not necessary. ${ }^{177}$ The need to move beyond relying only upon the incumbent as the universal service provider is reflected in the Third Postal Services Directive which now encourages the use of public procurement procedures in the funding of universal services. ${ }^{178}$

\subsection{How changes in demand / the abolition of the reserved market has led to increased} tensions on postal services - the UK and Germany

Despite the Commission's position, sustained for over two decades, that liberalisation and universal service could both be pursued successfully in tandem, this view has come under stress in recent years. The logic underpinning the reserved areas approach was that the incumbent would retain an ability to cross-subsidise the non-profitable elements of its service from the profitable ones. While the potential to do so was progressively lowered with the reduction in the scope of reserved areas, full liberalisation has left incumbents facing 'cherry-picking' by new entrant firms across all of their activities. New entrants have chosen selective entry, mainly offering their services in urban areas with a focus on the business to business market. They can also freely choose the quantity and quality of their collections and deliveries, not being subject to the USO requirements. In many rural and less populated areas, the former incumbent is still the only service provider, with the "final mile" of delivery remaining a natural monopoly. Incumbents then are forced to lower prices where they face new entry, and raise prices where they do not, undermining the sustainability of universal service, at least in the long-term.

One solution to this problem, of course, is to extend USOs to new entrants. However, doing so especially in the early days of liberalisation, may well have created significant barriers to entry and hinder competition. The same could be said, albeit to a lesser extent, of requiring new entrants to contribute to an incumbent's net costs via a compensation mechanism. Another

\footnotetext{
177 Ibid.

${ }^{178}$ Directive 97/67/EC, as amended by Directive 2008/6/EC, art 7(2).
} 
alternative is to reduce the scope of universal service (subject, of course, to the minimum requirements of the PSD). This has been done in a number of EU countries. ${ }^{179}$

In order to explore some of these issues further, we focus on recent developments in two Member States, Germany and the UK. These two countries were in the vanguard of opening their postal service markets to competition, well ahead of the 2010 deadline. ${ }^{180}$ The issue of the sustainability of universal service has come to the fore in both, with pressure from incumbents to reduce the scope of universal service. ${ }^{181}$

Currently in the UK, universal service obligations are only imposed on the incumbent, Royal Mail, and there is no compensation mechanism in place. In areas which an entrant does not wish to serve, it can choose instead downstream access, i.e., handing their postal items over to Royal Mail for final mile delivery. In Germany, Deutsche Post was designated as USP, but since the introduction of competition in 2008, its designation was removed, and no universal service provider is now designated. If universal service cannot be fulfilled by the market, then all licensed operators must provide the service jointly. ${ }^{182}$

\footnotetext{
${ }^{179}$ The frequency of delivery has been reduced to five days a week in the Netherlands and Italy. European Regulators Group for Postal Services, "Discussion paper on the implementation of Universal Service in the postal sector and the effects of recent changes in some countries on the scope of the USO" ERGP(14)16, 8 http://ec.europa.eu/internal_market/ergp/docs/documentation/2014/ergp-14-16-uso_en.pdf accessed 3 August 2016; PostNL, "General Conditions for the Universal Postal Service 2014", Article 20(1), file://ueahome/eresssf4/zgr08szu/data/Documents/general-conditions-universal-postal-service_tcm19-76269.pdf accessed 3 August 2016.

${ }^{180}$ The UK and German postal services markets were fully liberalised in 2006 and 2008 respectively. S Hough and L Booth, "Postal Services: Royal Mail plc" (2014) House of Commons, Standard Note, SN/EP/06763; Section 51(1) of the Postgesetz of 22 December 1997, BGBl. I, 3294, as amended by Art. 4 Abs. 106 G v. 7.8.2013, BGBl. I, 3154 .

${ }^{181}$ Both countries impose obligations which go further than is required by the PSD. The Postal Services Directive only requires the collection and delivery of letters and parcels from Mondays to Fridays, whereas in the UK and Germany letters are collected and delivered six days a week (Mondays to Saturdays) and in Germany the six days a week collection and delivery applies also for parcels. For a summary of USOs at European level, in Germany and the UK, see Harker at al., supra n 1, 35-38.

${ }^{182}$ If the German regulatory authority believes that the level of discharging universal service is not satisfactory, then all operators who have a licence, subject to a turnover threshold of 500,000 euros in the preceding calendar year, jointly provide universal postal service (section 12(1) of the Postgesetz of 22 December 1997, BGBl. I, 3294, as amended by Art. 4 Abs. 106 G v. 7.8.2013, BGBl. I, 3154). See C Feijoo and C Milne, "Re-thinking universal service policy for the digital era: setting the scene - an introduction to the special issue on universal service" (2008) 10 , info 4 .
} 
The levels of end-to-end competition (where the entrant collects, sorts and then distributes and delivers the mail) are low in the letter market as the vast majority of letters are still delivered by the former incumbent. ${ }^{183}$ In the UK, the most significant entrant was offering direct letter delivery in London, Liverpool and Manchester, but withdrew from the direct delivery market in 2015. ${ }^{184}$ However, despite an overall decline of letter volumes, the demand for downstream access has increased. ${ }^{185}$ In Germany, while there are hundreds of licensed operators, ${ }^{186}$ Deutsche Post delivers nearly 90 per cent of all (licensed) letters. ${ }^{187}$ In rural areas, consumers often do not have a choice between different providers and instead have to rely on the former incumbent. ${ }^{188}$ Downstream access also plays an important role in Germany. ${ }^{189}$

In both countries, the sustainability of universal service has been questioned. In the UK, Royal Mail regards itself as being at a competitive disadvantage compared with the other providers and has asked for a number of regulatory reviews of the USO scheme. In 2008, the Hooper Report acknowledged that universal service was under threat, mainly because of the declining letter market, but it also suggested that the incumbent was in a position to reduce its costs still further before any intervention was required. ${ }^{190}$ Two years later, in an update to the report, Hooper came

${ }^{183}$ In the UK, in 2013-14 only 0.6\% of letters by volume were delivered by providers other than Royal Mail, Ofcom, "Annual monitoring update on the postal market: Financial year 2013-14" (2014), paras 6.26-6.27, http://stakeholders.ofcom.org.uk/binaries/post/monitoring-reports/annual-monitoring-update-postal-2013-14.pdf accessed 3 August 2016

${ }^{184}$ BBC, "Royal Mail regulation to be reviewed by Ofcom" (16 June 2015), http://www.bbc.co.uk/news/business33145446 accessed 3 August 2016.

185 Ofcom, supra n 183, paras 6.20-6.23.

${ }^{186}$ At the end of 2013, there were about 600 licenced enterprises, many of them small or even micro businesses, Bundesnetzagentur, "Herausforderungen des Post-Universaldienstes Vorbereitung einer Stellungnahme gemäß § 47 Abs. 1 Satz 2 Postgesetz" (2014) Impulspapier, 2 http://www.bundesnetzagentur.de/SharedDocs/Downloads/DE/Sachgebiete/Post/Verbraucher/Universaldienst/Impul spapier.pdf?_blob=publicationFile\&v=1 accessed 3 August 2016.

${ }_{187}$ Bundesnetzagentur, "Marktuntersucherung Bericht über den lizenzpflichtigen Briefbereich 2015” (2016), 7, http://www.bundesnetzagentur.de/SharedDocs/Downloads/DE/Sachgebiete/Post/Unternehmen_Institutionen/Marktb eobachtung/LizenzpflichtigePDL/Marktuntersuchung2015.pdf?_blob=publicationFile\&v=5 accessed 3 August 2016.

${ }^{188}$ Monopolkommission, "Post 2013: Wettbewerbsschutz effectivieren" Sondergutachten 67, 27, http://www.monopolkommission.de/images/PDF/SG/s67_volltext.pdf accessed 3 August 2016.

${ }^{189}$ The majority of alternative postal provider carry out the entire service from collection to delivery of letters. Despite the fact that in 2012 more than $60 \%$ of all licensed letters carried out by the incumbents stemmed from downstream access, only a tenth of those products came from new entrants. Bundesnetzagentur, "Post 2012 /2013" (2013) Tätigkeitsbericht, http://www.bundesnetzagentur.de/SharedDocs/Downloads/DE/Allgemeines/Bundesnetzagentur/Publikationen/Beric hte/2013/131216_TaetigkeitsberichtPost2012.pdf?_blob=publicationFile\&v=3 3 August 2016.

${ }^{190}$ Richard Hooper, Deirdre Hutton and Smith Ian R, "Modernise or decline: Policies to maintain the universal postal service in the United Kingdom" (An independent review of the UK postal service sector, 2008), para 38, 
to the conclusion that the situation had become more serious. ${ }^{191}$ However, repeating the findings of the previous report, the 2010 Report found that Royal Mail still had the potential to increase further its efficiency before any reduction of the scope of the USOs would be contemplated. ${ }^{192}$ The postal regulator, Ofcom, has taken a very robust stance with Royal Mail. In a recent report on universal service in 2014, it dismissed Royal Mail's claims that it was unable to fulfil its USOs, stating unequivocally that universal postal service in the UK is "not under threat", and reiterated the need for Royal Mail to increase its efficiency. ${ }^{193}$

In Germany, similar issues have come to the fore and in 2014 the postal regulator, Bundesnetzagentur, launched an inquiry into the universal postal service. ${ }^{194}$ Since Germany is relying on the market to secure universal service, there is the real prospect that a declining letter market and increasing competition in parcel market may threaten the sustainability of USOs, at least in the long-term. Anticipating a further decline, and higher costs for the service providers, the regulator has emphasised the need for operators to increase their efficiency and develop new services. ${ }^{195}$ However, unlike its UK counterpart, the Bundesnetzagentur has signalled that it may be necessary to change the national and even the European regulatory framework to guarantee an adequate universal postal service in the future. This could involve both increasing and reducing the scope of USOs; new services that have been developed because of increased competition

https://www.gov.uk/government/uploads/system/uploads/attachment_data/file/228786/7529.pdf accessed 3 August 2016.

${ }^{191}$ Richard Hooper, "Saving the Royal Mail's universal postal service in the digital age: An Update of the 2008 Independent Review of the Postal Services Sector" (September 2010) para 7 https://www.gov.uk/government/uploads/system/uploads/attachment_data/file/31808/10-1143-saving-royal-mailuniversal-postal-service.pdf accessed 3 August 2016.

192 Ibid. Unlike the 2008 Report, the updated version concluded that the creation of a compensation fund should not be excluded per se, ibid, 40. For a discussion see L Booth and D Hough, "TNT Post and Royal mail: end-to-end competition in postal services" (2014) House of Commons Briefing Paper, http://researchbriefings.parliament.uk/ResearchBriefing/Summary/SN06935 accessed 3 August 2016.

193 Ofcom, "Securing universal postal service" (2 December 2014), http://stakeholders.ofcom.org.uk/post/securinguniversal-postal-service/ accessed 3 August 2016; The regulator also argued that selective entry does not create a 'cherry-picking' situation, ibid. More recently the BIS Select Committee, in a report published in March 2015, reached the conclusion that alternative providers are able to 'cherry-pick' but the current level is too low to require any regulatory action, Business, Innovation and Skills Committee, supra n 153, para 39, http://www.publications.parliament.uk/pa/cm201415/cmselect/cmbis/769/769.pdf accessed 3 August 2016. Ofcom has recently confirmed the position: Ofcom "Review of the Regulation of

Royal Mail” (25 May 2016), http://stakeholders.ofcom.org.uk/binaries/consultations/royal-mailreview/summary/Review-of-Royal-Mail-Regulation.pdf accessed 3 August 2016.

194 Bundesnetzagentur, supra n 186, 2.

195 Ibid, 2-3. 
could be brought within it (perhaps by combining universal service in telecoms), while the scope of traditional letter services may need to be reduced, especially in rural and less populated areas. ${ }^{196}$ Given that the incumbent is not subject to any formal requirement with respect to universal service, it is not surprising that the situation in Germany is seen as more urgent than it is in the UK.

\subsection{Compensation mechanisms for universal service in postal services}

In postal services, it appears that while the majority of Member States have legislated for the establishment of a compensation fund, as of 2013, only four have actually gone on to establish one. ${ }^{197}$ A further four compensate the USPs directly from public funds. ${ }^{198}$ For those countries which have actively considered the introduction of compensation mechanisms, there is a wide variety of views on the pros and cons of their implementation from a competition perspective. The Swedish NRA is of the view that designation is vital to protect competition since the designation procedure triggers the requirement of the PSD on cost-related pricing. ${ }^{199}$ On the other hand, the Spanish competition authority has been highly critical of the designation of the incumbent as the USP for a fifteen year period, which it considers to be contrary to both the spirit and the letter of the PSD. ${ }^{200}$ This approach, however, appears to represent the practice in other Member States; in all cases where a USP has been designated it has been the incumbent firm, despite the Third Postal Directive encouraging some level of contestability. ${ }^{201}$ It also appears that, subject to limited exceptions, the vast majority of users in Member States will have service levels which meet the minimum USO requirements of the Directive without the need for intervention. $^{202}$

\footnotetext{
196 Ibid, 5-6.

197 Dieke et al., supra n 83, 154.

198 Ibid. As of 2013, 22 have legislated for a compensation fund, while six have deemed that the USO represents an unfair burden on the USP. Ibid.

199 Ibid, 133.

${ }^{200}$ Comision Nacional de la Competencia, The new regulatory framework for the traditional postal sector in Spain (March 2011), cited in Dieke et al., supra n 83, 133.

${ }^{201}$ Dieke et al., supra n 83, 16.

202 This is the result of a survey of Member States which concludes that "the risk of persons lacking basic universal service appears to be confined to relatively small populations living in thinly populated rural areas”, ibid, 136.
} 
State aid fulfils a different role in postal services compared to broadband. In broadband, state aid is used to increase access to a service, whereas in postal services it is used to maintain the current level of services and secure a level-playing field between undertakings that provide USOs and alternative operators with no such obligation. State aid cases are relatively few. There have only been 27 State aid decisions concerning compensation for discharging SGEI in the postal sector between 2003 and 2014. ${ }^{203}$ All of the cases concerned compensation payments to the former incumbent and the majority of cases involved aid granted for the provision of services that go beyond the minimum objectives and conditions set out by the PSD. ${ }^{204}$

There are only a handful of State aid cases that concern only the funding of USOs as defined in the PSD. ${ }^{205}$ In both decisions, the subsidy granted by the Italian government to the incumbent, Poste Italiane, was held to be State aid as the fourth Altmark criterion had not been satisfied. There are a number of other cases where Member States have been found to be subsidising services which include but go beyond the definition of USO in the PSD. ${ }^{206}$ Although these may be capable of being disaggregated for the purposes of a State aid assessment, Member States are unlikely to set-up a separate compensation scheme under the PSD, with all of the administrative and bureaucratic architecture that implies, if there are other subsidies which have to be notified to the Commission. Of course, this has the effect in practice of excluding new entrants from fulfilling the USOs. Where compensation mechanisms are used, the Commission guards against market distortionary effects. For example, in a recent State aid decision concerning the Greek postal incumbent, ELTA, the Commission had to assess a compensation fund based on contributions by the incumbent's competitors. ${ }^{207}$ The Commission concluded the compensation

\footnotetext{
203 The cases were collected from the European Commission with the help of the EC's internal search engine $<$ http://ec.europa.eu/competition/elojade/isef/index.cfm>. The search focussed on cases for the economic sector "H.53 - Postal and courier activities" between 25.07.2003 (after Altmark) and 31.12.2014. The search was further refined by limiting the cases to compensation payments for the provision of SGEI. State aid decisions that concern subsidies paid to cover pension costs were excluded. Other cases not listed as a result of the online search but we became aware of through a review of the relevant literature so that 25 cases are part of the case law assessment. ${ }^{204}$ Services of General Economic Interest in postal services are, for example, the distribution of periodicals, the provision of basic financial services, the distribution of electoral material, and in some Member States even the payment of pensions. See, Competition Policy Brief, "High quality and competitive postal services for citizens and businesses - State aid control in the postal sector" (May 2014), 2 http://ec.europa.eu/competition/publications/cpb/2014/006_en.pdf accessed 3 August 2016.

${ }^{205}$ Decision NN51/2006 [2006] Poste Italiane SpA and Decision NN24/2008 [2008] Poste Italiane SpA.

${ }^{206}$ N462/2008 [2008] Poland; N312/2010 [2010] Poland; SA. 33989 [2012] Italy; SA.17653 [2013] Germany.

${ }^{207}$ Decision SA.35608 [2014] Hellenic Post (ELTA).
} 
scheme was incompatible as it appeared to place a disproportionate burden on new entrants, requiring them to make a contribution of up to 10 per cent of their turnover, thereby creating barriers to entry or even forcing them to exit the market. ${ }^{208}$

\subsection{Conclusions}

The findings of our case study suggest that the compensation mechanisms in the PSD have not been widely used. In many Member States, the incumbent provides services that go beyond the minimum requirement of universal postal service, but then struggles to finance those services, relying on state subsidies to maintain historic service levels. In those countries, such as the UK and Germany, where liberalisation has advanced significantly, incumbents have argued that universal service is unsustainable given the ability of new entrants to 'cherry-pick' the most profitable customers. Such arguments are likely to gain traction as demand for letter collection and delivery declines in the future.

\section{E. Conclusions}

In this paper we have considered the protection of universal service in the network industries, with a focus on telecommunications and postal services.

As has been observed in the literature, the protection of universal service was essentially a quid pro quo for liberalisation of the network industries. The EU sectoral legislation represented a compromise between these competing values; it sought to give formal legal protection to USOs and, in anticipation of full liberalisation and the eventual reduction of incumbents' market shares, put in place detailed and elaborate mechanisms for compensating the costs of serving disadvantaged and unprofitable consumers. As we have demonstrated, to a surprising degree, these provisions have remained dormant. Where they have been tested, they have demonstrated themselves to be particularly complex and cumbersome. The substantive rules, as interpreted by the Court and the Commission, have been framed primarily to promote contestability in the

\footnotetext{
${ }^{208}$ Ibid, para 193-194.
} 
provision of universal service and to avoid the danger of over-compensation to the USP (the incumbent in the vast majority of cases). It is difficult to avoid the conclusion that the limited use of compensation mechanisms is due in no small part to the complexity of the underlying sectoral rules.

Another surprising finding in this paper is the degree to which the State aid regime has been used as an alternative mechanism for funding USOs. ${ }^{209}$ Indeed, with respect to the public funding of investment in broadband infrastructure, this appears to be the result of a deliberate policy decision on the part of the Member States, albeit with a strong steer from the Commission. There is nothing new or novel in the use of the general competition rules as an alternative to sectoral regulatory tools. ${ }^{210}$ The more pertinent and interesting question from our point of view is why Member States would prefer to channel compensation schemes for approval under the State aid regime, rather than relying upon the detailed procedural and substantive rules contained in the Directives. It is difficult to avoid the conclusion that the State aid regime is preferred because of its flexibility, and the legal certainty resulting from the Commission's ex ante role in scrutinising the Member States' interventions in these markets.

State aid rules are not unproblematic. As a judge of the CJEU, Thomas von Danwitz, has observed, the State aid rules are not necessarily an appropriate tool in this context: "we have to acknowledge that state aid control is not a generally usable, unconditioned instrument of regulatory policy for realising a level playing field in liberalised markets. State aid control is rather focused on the use and abuse of state resources in a competitive environment". ${ }^{211}$

Under the State aid rules, the Commission has substantial control over Member States' autonomy when it comes to protecting and promoting universal service. Where an EU norm exists in

\footnotetext{
209 The Commission takes the rather surprising view that compensation payments for the provision of USOs through a compensation fund set up under the PSD is State aid and, therefore, assesses the compatibility under the State aid regime (Hellenic Post, supra n 207). We disagree with this approach.

${ }^{210}$ For a detailed discussion see M Harker, "EU Competition Law as a Tool for Dealing with Regulatory Failure: The Broadband Margin Squeeze Cases" (2013) Journal of Business Law 817; N Dunne, "Margin Squeeze: From Broken Regulation to Legal Uncertainty" (2011) 70 Cambridge Law Journal 34; D Geradin and R O'Donoghue, "The Concurrent Application of Competition Law and Regulation: The Case of Margin Squeeze in the Telecommunications Sector" (2005) 1 Journal of Competition Law and Economics 355.

${ }^{211}$ von Danwitz, supra n 23, 12.
} 
secondary legislation (as in the case of both the USD and PSD), Member States retain some measure of discretion to go beyond that norm, but a stricter test of proportionality obtains, requiring Member States demonstrate that the State aid measure is the least restrictive means of achieving the objective in question. ${ }^{212}$ Furthermore, the Commission has sought to limit the discretion that Member States enjoy in the design of compensation mechanisms, maximising the boundaries of its supervisory powers by its restrictive interpretation of the Altmark criteria and Article 106(2).

Controlling Member States' autonomy when intervening in markets is not the same task as regulating to ensure that the aims and objectives of regulation are being fulfilled. As we explained, the State aid rules, as they are now to be interpreted under the 2012 SGEI package, have been realigned to promote contestability in public service provision. Nevertheless, the public procurement requirement introduced by the SGEI Framework is by no means a panacea. While the intention is to encourage more contestability in the provision of SGEI, it may be that tendering does not result in the best outcomes. ${ }^{213}$ Asymmetries of information may have the effect that the winning bidder actually puts forward a bid which is too low to recover the costs of universal service. Furthermore, procurement procedures cannot prevent undertakings colluding in order to achieve higher compensation payments. And even though an incumbent may be able to offer to fulfil USOs at the lowest cost, it will have an incentive to bid-up its price as the costs of its competitors will in general be higher. There are also potential problems when it comes to specifying and securing service levels as there are incentives on bidders to compete purely on price rather than quality of service. ${ }^{214}$ While using a tendering process obviates the need for Member States to engage in the complex requirements under the Directives, reliance solely on the EU public procurement rules is not an effective substitute for regulation; they do not involve an effective ex post check on the accounts of the incumbent to avoid any over-compensation. ${ }^{215}$

\footnotetext{
212 Sauter, supra n 15, 180-81; see also Ross, supra n 67, 136-8; Fiedziuk, supra n 23; Klasse, supra n 35, 50-51.

${ }^{213}$ N Fiedziuk, "Putting services of general economic interest up for tender: reflections on applicable EU rules" (2013) 50 Common Market Law Review 87, 93.

${ }^{214}$ EAGCP, supra n 35, 6-7.

${ }^{215}$ Ibid, 6; Klasse, supra n 35, 46-47; Fiedziuk, supra n 213, 93-96.
} 
Furthermore, the State aid rules may not be engaged at all where the compensation payments are not capable of being imputable to the state. ${ }^{216}$

There will often be trade-offs between pursuing liberalisation policies while at the same time seeking to protect vulnerable and disadvantaged consumers from some of the adverse consequences of competition. The core issue is whether these trade-offs are better made within a framework which seeks to give formal protection to specified levels of universal service, while at the same time putting in place safeguards - procedural and substantive - aimed at minimising distortions of competition. There are a number of dangers, outlined above, in relying upon the State aid regime to control Member States' compensation of USOs. However, in our view, the key problem is that the State aid regime gives insufficient protection to the importance of universal service. The State aid rules are permissive; they do not require Member States to put in place mechanisms for compensation where the fulfilment of USOs require it. The danger is that such a discretionary approach to securing universal service will result in a diminution of USOs, leading to less protection for vulnerable and disadvantaged consumers. The Commission has been more concerned with ensuring that interventions in support of universal service do not produce disproportionate market distortions, that the incumbent is not over-compensated, and that new entrant firms are not excluded from being the USP. Very little, if any, attention has been paid to whether the USOs are in fact being fulfilled and, of equal importance, are being appropriately updated in the light of changing demand, technological and market conditions. It is difficult to avoid the conclusion that universal service, as a formal EU regulatory norm in the network industries, is in managed decline.

\footnotetext{
${ }^{216}$ On the problem of imputability see von Danwitz, supra n 23, 7-8. The extent to which an industry compensation scheme constitutes State aid is by no means straightforward. It depends upon whether the scheme is deemed to meet the cumulative conditions of being "aid granted by the State" and "through State resources". The latter condition may be particularly difficult to meet in cases where the contributions towards an industry compensation scheme are made only by private undertakings and are not redistributed via a public institution (see Case C-379/98 PreussenElecktra AG [2001] ECR I-2099). See M Clayton and M Catalan, "The Notion of State Resources: So Near and yet so Far" (2015) (2) European State Aid Law Quarterly 260 for a discussion of recent case law. It would appear vital that the scheme is both administered by a state institution and that there is state control over how the resources collected are distributed. However, the 2012 SGEI Communication posits that "compensatory payments for the operation of SGEIs which are financed through parafiscal charges or compulsory contributions imposed by the State and managed and apportioned in accordance with the provisions of the legislation are compensatory payments made through State resources." Commission, supra n 48, Recital 36.
} 
2

3

4

\title{
Universal service obligations and the liberalisation of network industries: taming the
} Chimera?

\author{
Professor Michael Harker and Antje Kreutzmann-Gallasch
}

\author{
Professor Michael Harker (corresponding author) \\ Law School, University of East Anglia \\ Norwich Research Park \\ Norwich, NR4 7TJ \\ 01603592406 \\ m.harker@uea.ac.uk \\ Antje Kreutzmann-Gallasch \\ Law School, University of East Anglia \\ Norwich Research Park \\ Norwich, NR4 7TJ \\ a.kreutzmann@uea.ac.uk
}

Word count: c.11500 


\begin{abstract}
This paper considers the protection of universal service in the network industries, with a focus on the postal service and telecommunications sectors. We define the concept of universal service and explain how it was seen as a necessary quid pro quo for securing the liberalisation agenda in the EU. We go on to explain and analyse the two competing means of protecting and compensating universal service, either under the State aid regime or the relevant sectoral legislation. In order to gain a better understanding of how these competing mechanisms operate in practice, we look in detail at two areas where liberalisation and universal service are in particular tension: (i) high-speed broadband and (ii) letter collection and delivery. We conclude by discussing some of the problems of using State aid rules as a substitute for a sectoral framework and contemplate the future of universal service.
\end{abstract}

Keywords: competition law, State aid, Service of General Economic Interest, Universal Service Obligation, telecommunications, postal services, compensation. 


\section{A. Introduction}

Over the last three decades, the EU has been pursuing a liberalisation agenda across all of the network industries - telecommunications, postal services, energy, water and railways. A concern to arise from this is that when traditionally monopolised markets are opened to competition, new entrants may be able to enter and target the most profitable consumers, leaving the incumbent with a disproportionate number of consumers who provide insufficient revenue to cover their costs. This is a particular problem where there have historically been extensive cross-subsidies in favour of groups of consumers who are viewed as vulnerable, deserving or politically sensitive (for example, those living in rural areas). As a consequence, it is often politically difficult or socially undesirable to achieve cost-reflective pricing through tariff rebalancing.

The response in the EU has been to formalise the protection of certain classes of customers through the imposition of universal service obligations (USOs). In the early days of liberalisation, such obligations were normally imposed on the incumbent without it being compensated; its size and the advantages it had derived as the historic monopolist meant that it could afford to absorb these additional costs without being placed at a significant competitive disadvantage. The effectiveness of this approach to universal service begins to unravel where the market share of the incumbent is significantly eroded by new entry, or where new investment is needed in network infrastructure. In the long-run, a sustainable approach to funding universal service has to be found.

In this paper, we consider the legal responses to the protection of the universal service in the EU. In section B, we define what is meant by USOs, and explain some of the potential market distortions that can occur in pursuing them, including how entrants and incumbents may be placed at a competitive (dis)advantage. While there are inherent tensions in attempting to secure universal service alongside liberalisation, a number of EU Member States would never have accepted the latter goal without some formal protection for the former. However, in more recent years, the policy emphasis has shifted towards the introduction of contestability into the provision of universal service with an attempt to reverse the de facto presumption of the incumbent's continuation of the role. In section C, we explain and compare the legal frameworks 
for universal service provision. In the network industries, the relevant EU secondary legislation often prescribes both the requirements of USOs and the means by which compensation may be made to those entrusted with its provision. Alternatively, as a subset of Services of General Interest (SGEIs), Member States may instead choose to make compensation payments to universal service providers (USPs) under the State aid regime, as reformed by the 2012 SGEI package. As we explain, in recent years, under both the sectoral and State aid regimes, increased emphasis has been placed upon contestability in the provision of universal service. In section D, we have selected two contrasting areas to investigate further. The first relates to the provision of high-speed broadband, the expansion of which requires substantial investment in infrastructure, both public and private. What is particularly striking here is that Member States have eschewed the secondary legislation, and the sectoral rules on compensation which it contains, in favour of making use of the State aid regime. The second area is postal services, in particular the collection and delivery of letters. The provision of universal service has come under particular strain in recent years due to increased liberalisation and dramatic falls in demand. Nevertheless, we see here very little use of compensation mechanisms, either under the sectoral or State aid regimes, with a focus instead on incumbents achieving efficiency gains. In section E, we conclude, contemplating the future of universal service, its sustainability, and the extent to which it is subordinated to pro-competition goals.

\section{B. Universal service obligations and liberalisation}

In this section, we first define what is meant by universal service, before proceeding to explain some of the tensions that exist between its protection and the promotion of liberalisation and competition in the network industries. We discuss how the protection of universal service in the EU was essentially a political compromise by Member States in accepting the EU's liberalisation agenda for the network industries. We then explain how universal service can be secured, particularly by utilising the various options that exist in the design of compensation mechanisms. 


\footnotetext{
${ }^{1}$ For a comprehensive review of the literature see M Harker, A Kreutzmann and C Waddams, "Public service obligations and competition", (2013) CERRE, Final Report, 23-46, http://www.cerre.eu/sites/cerre/files/130318_CERRE_PSOCompetition_Final_0.pdf accessed 3 August 2016. ${ }^{2}$ Colin R Blackman, “Universal service: obligation or opportunity?" (1995) 19 Telecommunications Policy 171, 172.

${ }^{3}$ On social exclusion, see E Szyszczak, The regulation of the state in competitive markets in the EU (Oxford, Hart Publishing, 2007) 243.

${ }^{4}$ F Mirabel, JC Poudou and M Roland, "Universal service obligations: The role of subsidization schemes" (2009) 21 Information Economics and Policy 1, 7.
} 
including the intended beneficiaries of the policy. ${ }^{5}$ The imposition of USOs may also reduce entry, especially if the obligations are imposed on entrants. ${ }^{6}$

One particular problem with USOs is "cherry-picking", i.e., where new entrants target the most profitable consumers, leaving the incumbent with those consumers who provide insufficient revenue to cover their costs. ${ }^{7}$ While this may be sustainable in the short term, as new entrants establish their position on the market, in the long run the incumbent's costs will be forced upwards, meaning it will either be required to increase its prices, or some form of compensation mechanism will have to be employed (for example, an industry compensation scheme). Such mechanisms are not without their own problems and may lead to the over-compensation of the incumbent. ${ }^{8}$ It may also mean that certain classes of customers are left with the incumbent provider, who is perhaps offering an inferior level of service to that which would be available to them in a competitive environment. ${ }^{9}$ This tends to emphasise the importance of analysing the counterfactual, i.e., the market conditions which would prevail absent the USO. Indeed, it may even be the case that the imposition of USOs on the incumbent provider may actually place it at a competitive advantage vis-à-vis new entrants, especially where it is over-compensated for the cost of providing the USO.

From a political perspective, it is often difficult to withdraw USOs, especially where doing so may lead to the erosion of cross-subsidies leading to adverse distributional consequences. ${ }^{10}$

\footnotetext{
${ }^{5}$ Calzada demonstrates that uniform pricing will affect the development of competition enabling the entrant to enter in a limited way, increasing both the incumbent's prices and the profitability of both players, J Calzada "Universal service obligations in the postal sector: The relationship between quality and coverage" (2009) 21 Information Economics and Policy 10, 18; Hviid and Waddams Price show how non-discrimination clauses imposed in the UK energy markets result in higher prices for all consumers, M Hviid and C Waddams Price, "Non-Discrimination Clauses in the Retail Energy Sector" (2012) 122 The Economic Journal, F236.

${ }^{6}$ S Hoernig and TE Pinto, "Universal Service Obligations: Should they be imposed on entrants?" (2001) ftp://193.196.11.222/pub/zew-docs/div/IKT/hoernig.pdf accessed 3 August 2016.

${ }^{7}$ L Rapp, "Public service or universal service?" (1996) 20 Telecommunications Policy 391, 394; G Simmonds, "Consumer Representation in Europe Policy and Practice for Utilities and Network Industries, Universal and Public Service Obligations in Europe" (2003) CRI Research Report 15/2003, 8. http://www.bath.ac.uk/management/cri/pubpdf/Research_Reports/15_Simmonds.pdf accessed 3 August 2016. ${ }^{8}$ A Gautier and X Wauthy, "Competitively neutral universal service obligations" (2012) 24 Information Economics and Policy 254, 259-60.

9 JC Panzar, "A methodology for measuring the costs of universal service obligations" (2000) 12 Information Economics and Policy 211.

${ }^{10}$ See OECD, "Rethinking Universal Service for a Next Generation Network Environment" (2006) OECD Digital Economy Papers 113, 22-23, http://dx.doi.org/10.1787/231528858833 accessed 3 August 2016.
} 

Tariff rebalancing may be perceived as inequitable where it leads to higher prices for lower income and rural consumers, and may even result in some consumers disconnecting from the network altogether. ${ }^{11}$ The political sensitivity of tariff rebalancing may be employed by incumbents to resist liberalisation, or to slow its pace, and there is certainly evidence from the past that incumbents have used its spectre as a means of resisting liberalisation. ${ }^{12}$

While there are obvious tensions between liberalisation and USOs, it may be that there is a more nuanced relationship between the two. First, the formal recognition of USOs was seen as a quid pro quo for further liberalisation, especially for Member States like France that have a strong tradition of public service in utilities. ${ }^{13}$ In this context then, USOs may be characterised as a "means to protect the weakest citizens from market liberalization". ${ }^{14}$ So without the strengthening of USOs in law, the achievement of liberalisation policies at the EU level would have been more difficult. Second, liberalisation and USOs may serve the same ends. Increased competition may lead to lower prices, greater efficiency and increased affordability. Furthermore, the formal legal status and specification given to USOs, while differing significantly between sectors, may lead to more meaningful (and enforceable) rights for consumers. ${ }^{15}$ The clearer specification of USOs also increases certainty for market players, including new entrants.

\footnotetext{
11 Ibid.

12 The UK gas incumbent, British Gas, provided an early example of such lobbying in its evidence to the 1993 Monopolies and Mergers Commission Inquiry into opening the market. They predicted huge increases in fixed charges, less than a decade before they themselves abolished them in the competitive market, see M Bennett, D Cooke and C Waddams Price, "Left out in the cold? New energy tariffs, low-income households and the fuel poor" (2005) 23 Fiscal Studies 167.

13 T Prosser, The limits of competition law: Markets and public services (Oxford, Oxford University Press, 2005), 106-13. For a comparative discussion, see KA Eliassen and J From, "Deregulation, privatisation and public service delivery: Universal service in telecommunications in Europe" (2009) 27 Policy and Society 239.

${ }^{14}$ M Finger and D Finon, "From "service public" to universal service: the case of the European Union" in M Finger and RW Künneke (eds), International handbook of network industries: The liberalization of infrastructure (Cheltenham, Edward Elgar Publishing Limited, 2011), 55.

${ }^{15}$ W Sauter, "Services of general economic interest and universal service in EU law" (2008) 33 European Law Review 167, 178.
} 
There are potential downsides to greater specification of USOs. ${ }^{16}$ The concept of universal service is a dynamic one, which needs to adapt to changing societal and technological needs. ${ }^{17}$ Issues of particular concern include affordability in the light of changing living standards, changing perceptions of what is an essential service (for example, access to the internet is increasingly perceived as a basic need), and the danger of locking in services which are no longer used extensively nor judged as essential. So where USOs remain static and highly specified, they may become outmoded or irrelevant. ${ }^{18}$

While some form of compensation may be necessary in order to achieve USOs, there are a number of different models which can be chosen, and the incumbent firm is not necessarily the best candidate for discharging the USO. One option is to remove the subsidies from the competitive retail supply market and deliver them through other means, for example, via a monopoly distribution network (where one exists). This occurs in many distribution networks where rural consumers are subsidised by urban consumers by the charging of uniform distribution prices. A second option is to grant special or exclusive rights over certain markets to the universal service provider, preserving its ability to cross-subsidise between profitable and non-profitable customers. This was the model used until recently in postal services. A third option, which tends to be the default regulatory choice, is to allow the incumbent to carry the costs without compensation because it enjoys other advantages. In the long run, as liberalisation gathers pace, it is unlikely that failing to compensate the incumbent will be sustainable. This then raises the vexed question of how to calculate the net costs and benefits for the purpose of

\footnotetext{
${ }^{16}$ The actual level of specification differs significantly between sectors. For post and telecommunications, there is more detailed specification of the universal service requirements in EU law than is the case for the other network industries, in particular, transport, water and electricity. This can, in part, be attributed to the structural characteristics of the different network industries (for example, the amount of cross-border trade); and in part to the historical traditions in the Member States with regard to the definition and implementation of universal and public service provisions in these sectors. See Simmonds, supra n 7, 61; Prosser supra n 13, 174-206; and for a full survey, see Harker et al., supra n 1, 65-73.

${ }^{17}$ J Alleman, P Rappoport and A Banerjee, “Universal service: A new definition?” (2010) 34 Telecommunications Policy 86, 90; J Davies and E Szyszczak, "Universal Service Obligations: Fulfilling New Generations of Services of Economic Interest", in E Szyszczak (ed), Developments in Services of General Interest (The Hague, T.M.C. Asser Press, 2011) 162-71; A Kreutzmann-Gallasch et al, "Criteria to define essential telecoms services" (2013) A Report for Ofcom by the ESRC Centre for Competition Policy, 9-16.

${ }^{18}$ Kreutzmann-Gallasch et al, supra n 17; Harker et al, "Competition for UK postal sector and the universal service obligation" (2014) BIS Consultation response from the ESRC Centre for Competition Policy, http://competitionpolicy.ac.uk/documents/8158338/8261737/CCP+Response+-+BIS++Competition+for+UK+Postal+Sector.pdf/364e21b3-6296-4ee9-8e4d-945b696e8235 accessed 3 August 2016.
} 
compensating the universal service provider. ${ }^{19}$ There are two possible sources of compensation. One is an industry compensation scheme whereby entrants compensate the incumbent for fulfilling the relevant USO. Another is compensation directly from public funds. In either case, there is the problem that the incumbent will be over-compensated because, as with regulation more generally, it enjoys an informational advantage over, and an incentive to exaggerate, its costs. In addition, the incumbent may enjoy certain other intangible benefits in being appointed as universal service provider, for example, brand ubiquity.

There is no reason, however, why the incumbent should be the universal service provider. An auction could be held for supplying consumers who require enhanced services or who are lossmaking, inviting bids to supply them with a subsidy. This is similar to the franchising arrangements for loss making transport routes, and has the obvious advantage of potentially revealing the most efficient provider. Another option is to require all suppliers to either 'pay or play', so that either they supply a particular portion of the loss making consumers, or pay a contribution (in proportion to their market share) into a central fund which is then distributed to those who do. ${ }^{20}$ As we discuss in the remainder of this paper, substantial efforts have been made in recent years to expand the provision of universal service beyond the historic incumbents, albeit with varying degrees of success.

\section{The funding of universal service in a changing environment}

In this section we explain the legal frameworks which govern the compensation of universal service. First, since USOs are generally accommodated within the Treaty - as a subset of SGEI -

\footnotetext{
${ }^{19}$ A paper by Rodriguez and Storer pays considerable attention to the calculation of USOs. Two main approaches are suggested: the net avoided cost and the entry pricing approach, but both have their difficulties. F Rodriguez and D Storer, "Alternative approaches to estimating the cost of the USO in posts" (2000) Information Economics and Policy 285. In a later report on telecoms, the OECD reports on the difficulties in estimating the net cost of providing universal service, including identification of the intangible benefits which might accrue to the universal service provider, and the adverse effect such uncertainty might have on investment in the sector: OECD, supra $\mathrm{n} 10,18$. ${ }^{20}$ For a discussion see P Choné, L Flochel and A Perrot, "Universal service obligations and competition" (2000) 12 Information Economics and Policy 249. The OECD is of the view that such processes can "generate incentives to contain costs, innovate, and reveal the true cost of delivering universal service thus minimising the subsidy required" (OECD, supra n 10, 5). It points to some success in competitive tendering in Chile and Peru, although less success in Australia and Switzerland (where trials resulted in no competitive entry) (OECD, supra n 10, 18).
} 
compensation for the costs generated by them may be justified, even if this requires a derogation from the EU competition rules, including the State aid rules. ${ }^{21}$ We therefore sketch briefly the main principles and requirements for compliance with the State aid rules. Second, the general rules on State aids and SGEIs have, to a certain extent, been displaced by the rules contained in the EU secondary legislation which both define universal service goals and lay down the procedural and substantive provisions for compensation. While these sectoral rules have been in place for a number of years, they have been left largely inactive by Member States due to the incumbents' ability to maintain cross-subsidies without explicit compensation. Indeed, as we explain, the compensation provisions are only triggered if and when the USP can demonstrate that the USO imposes upon it an 'unfair burden', which is by no means straightforward. In recent years the Commission has used its enforcement powers in numerous instances, especially where compensation mechanisms appear to be over-compensating the incumbent, or are designed in such a way as to exclude entrants from being designated as a USP.

\section{State aid, universal service, and Services of General Economic Interest}

While no explicit mention is afforded to universal service in the Treaty on the Functioning of the European Union (TFEU), ${ }^{22}$ the concept is generally considered to fall within the scope of SGEI, which are given specific protection under the TFEU, primarily under Article 106(2). ${ }^{23}$

\footnotetext{
${ }^{21}$ Indeed, in theory, where compensation exists which does not exceed the net cost of providing the USOs, undertaking(s) charged with their fulfilment are not placed at a competitive advantage, and so the State aid rules are not engaged at all.

${ }^{22}$ Consolidated Version of the Treaty on the Functioning of the European Union [2012] OJ C 326/47. Unless indicated otherwise, all further references are made to the TFEU.

${ }^{23}$ SGEIs are also given protection under Article 14 TFEU, Protocol 26 to the TFEU and Article 36 of the Charter of Fundamental Rights. On the effects of Article 14, Protocol 26, and Art 36 of the Charter of Fundamental Rights: Sauter argues that these provisions add substantively little to Article 106(2), see W Sauter, supra n 15, 174; W Sauter, Public services in EU law (Cambridge, Cambridge University Press, 2015) 12. For a general discussion see N Fiedziuk, "Services of general economic interest and the Treaty of Lisbon: opening doors to a whole new approach or maintaining the "status quo"” (2011) 37 European Law Review 226. On the other hand, von Danwitz argues that their adoption is "the culmination point in the fight for a specific legal status for public services" (T von Danwitz, "The Concept of State Aid in Liberalised Sectors", (2008) EUI Working Papers LAW 2008/28, 1 http://cadmus.eui.eu/bitstream/handle/1814/9588/LAW_2008_28.pdf?sequence=1 accessed 3 August 2016).
} 
Notwithstanding the various attempts by the Commission to define SGEI ${ }^{24}$ (and USOs), ${ }^{25}$ Member States have a measure of discretion in defining a service as a SGEI. ${ }^{26}$ This approach allows Member States to establish, extend and adjust the provision of particular services to specific national needs, subject to certain limiting principles developed by the EU courts. That said, in recent years the Court has held that services can only be categorised as a SGEI if it can be demonstrated that the service would not otherwise be provided through the market - the 'market failure' requirement - which significantly limits the apparently broad discretion of Member States. ${ }^{27}$ For example, in a recent case concerning high-speed broadband, the General Court confirmed that the presence of market failure is a necessary condition for a SGEI. ${ }^{28}$

Although external financing may be necessary to secure the provision of USOs, it can also distort competition. Article 106(2) contains a derogation from the application of the competition rules, including the general prohibition on State aids. However, where the payment made to a universal service provider goes no further than merely compensating the undertaking for the net costs of fulfilling the USO, there is in principle no market distortion, since it is not placed at a competitive advantage vis-à-vis its competitors.

In the past there was no clear understanding of whether payments for the provision of SGEIs were to be regarded merely as compensation for discharging those services (the "compensation

\footnotetext{
${ }^{24}$ The term 'SGEI' also lacks a clear definition. However, the European Commission has sought to clarify and define the concept of SGEI in several of its policy documents, for example, as "economic activities which deliver outcomes in the overall public good that would not be supplied (or would be supplied under different conditions in terms of quality, safety, affordability, equal treatment or universal access) by the market without public intervention". European Commission, "A Quality Framework for Services of General Interest in Europe", (Communication) COM (2011) 900 final, 5.

${ }^{25}$ In the 2011 Communication, the Commission referred to USOs as: "requirements designed to ensure that certain services are made available to all consumers and users in a Member State, regardless of their geographical location, at a specified quality and, taking account of specific national circumstances, at an affordable price". Ibid, 4 . This definition is in line with Article 3(1) of Directive 2002/22/EC (Universal Service Directive) [2002] OJ L108. ${ }^{26}$ The Treaty allows Member States and their local, regional and national public authorities broad discretion to define a service as being SGEI (and USO). Case T-17/02 Olsen v Commission [2005] ECR II-2031, para 216 (confirmed by order of the Case C-320/05P Olsen $v$ Commission [2007] I-131 ECR).

${ }^{27}$ Whether or not a service is provided through the market is then addressed by the test for "manifest error of assessment", Olsen v Commission, supra n 26, para 166. For a defence of this position see Sauter, supra n 15, 178.

${ }^{28}$ In the Colt case, the existence of market failure was assumed when the Member State can demonstrate that the service will not be provided by the market within the near future, Case T-79/10 Colt Télécommunications France $v$ European Commission ECLI:EU:T:2013:463, para 153. Earlier, the General Court ruled in BUPA that in order to pass this test, a SGEI must have a "universal and compulsory nature" and the Member State is obliged to explain why a particular service is to be regarded as SGEI, Case T-289/03 BUPA [2008] II-81 ECR, para 172.
} 
approach"), or as State aid (the "State aid approach"). Under the State aid approach, each payment to an entrusted undertaking was considered as State aid within the meaning of Article 107(1) and, therefore, incompatible with the internal market unless they satisfied one of the public interest exceptions contained in Article 107(2-3). However, even if the compensation in question did not satisfy the State aid exceptions, it could still be justified under Article 106(2). Even though the payment may ultimately be compatible with the internal market, the Commission must be notified of it in advance and the Member State is required to wait for the Commission's approval before making the payment (the standstill obligation). ${ }^{29}$ In contrast, under the compensation approach, payment for the pure recovery of the undertaking's net costs (including a reasonable profit) for the delivery of a SGEI is to be regarded as merely compensatory and not as State aid. Such a payment would be compatible with the internal market without recourse to the public interest exceptions nor the derogation under Article 106(2). Further, as it is not regarded as State aid, a prior assessment by the Commission is not necessary. ${ }^{30}$ In practice, therefore, the main difference between the two approaches is the notification requirement and standstill obligation under the State aid approach, which obviously gives the Commission more control over Member States' autonomy.

In terms of the jurisprudence, it is fair to say that, while the EU courts have not been entirely consistent, the compensation approach dominates. ${ }^{31}$ The issue was apparently settled in the Altmark case, ${ }^{32}$ where the Court confirmed that the compensation approach was the correct one to be followed, confirming as a point of principle that provided the undertaking does not receive over-compensation for the fulfilling its public service mission, such payments do not put it at a competitive advantage within the meaning of Article 107(1). ${ }^{33}$ The Court went further, however,

\footnotetext{
${ }^{29}$ Art 108(3).

${ }^{30}$ L Hancher and P Larouche, "The Coming Age of EU Regulation of Network Industries and Services of General Economic Interest" in PP Craig and G de Búrca (eds), The evolution of EU law (Oxford, Oxford University Press, 2nd edn, 2011) 759; A Jones and B Sufrin, EU competition law (Oxford, Oxford University Press, 5th edn, 2014), chapter State aid, 67-8; For a detailed discussion of the compensation approach and the state aid approach, see Szyszczak, supra n 3, 222-28.

${ }^{31}$ For examples of the compensation approach, see: Case C-240/83 Procureur de la République v ADBHU [1985] ECR 531, para 18; Case C-53/00 Ferring [2001] ECR I-9067, para 27. For examples of the State aid approach, see: Case C-387/92 Banco Exterior de Espana SA v Ayuntamiento de Valencia [1994] ECR I-877, paras 20-22.; Case T106/95 FFSA and Others v Commission [1997] ECR II-229, para 172; Case T-46/97 SIC v Commission [2000] ECR II-2125, para 84.

32 Case C-280/00 Altmark Trans [2003] ECR I-7747.

33 Ibid, para 92.
} 
by developing four cumulative criteria which have to be met for a payment to fall outside of the scope of Article 107(1) ("the Altmark criteria"). ${ }^{34}$ Despite the apparent clarity of the Court's criteria, their application has not been unproblematic. The fourth criterion - requiring that the undertaking is either selected by a public procurement process or that compensation should reflect the costs of a "typical, well-run undertaking" (hereafter "the efficiency benchmark") - has been very difficult to apply in practice. ${ }^{35}$ However, in BUPA, this requirement was relaxed by the General Court. Depending on the established compensation scheme in place, an efficiency benchmark may not be needed, even in cases in which the undertaking was not entrusted by an act of public procurement. ${ }^{36}$ Furthermore, in the Deutsche Post case, ${ }^{37}$ the General Court set aside the Commission's State aid decision principally on the ground that it had failed to assess sufficiently whether the payments received by Deutsche Post amounted to over-compensation (as it was required to do in applying the third Altmark criteria). ${ }^{38}$ The decision of the General Court was upheld by the Court, ${ }^{39}$ and the case is seen as an important confirmation of the Altmark criteria and the "compensatory approach" which underpins it. ${ }^{40}$

\footnotetext{
${ }^{34}$ The criteria can be summarised as follows: First, the recipient undertaking must actually have "public service obligations" to discharge, and the obligations must be clearly defined. Second, the method by which the compensation is calculated must be established in advance in an objective and transparent manner. Third, the compensation cannot exceed what is necessary to recover costs incurred. Fourth, the undertaking discharging the public service must either be chosen by a public procurement procedure or the level of compensation should reflect the cost of a "typical, well-run undertaking", ibid, paras 88-94.

${ }^{35}$ Hancher and Larouche, supra n 30, 761 - 2; See also M Klasse, "The Impact of Altmark: The European Commission Case Law Responses" in E Szyszczak and JW van de Gronden (eds), Financing Services of General Economic Interest (The Hague, T. M. C. Asser Press, 2013) 36-7; EAGCP, "Services of General Economic Interest" (2006) Opinion prepared by the State aid Group of EAGCP, http://ec.europa.eu/competition/state_aid/studies_reports/sgei.pdf accessed 3 August 2016.

${ }^{36}$ BUPA, supra n 28, paras 245-8. However, the Commission is still required to examine whether the compensation does not result from any inefficiencies of the service provider (ibid, para 249.). See NA Matos, "The Role of the BUPA Judgement in the Legal Framework for Services of General Economic Interest" (2011) 16 Tilburg Law Review 83, 86-9. In the Chronopost judgment, three weeks prior to Altmark, the ECJ decided that in markets where there is no undertaking to compare the incumbent's costs with, compensation cannot be based on market conditions but rather must "be assessed by reference to the objective and verifiable elements which are available" (Joined Cases C-83/01P, C-93/01P; C-94/01P Chronopost [2003] ECR I-6993, paras 38-40).

${ }^{37}$ Case T-266/02 European Commission v Deutsche Post AG and others ECLI:EU:T:2008:235.

${ }^{38}$ In particular, the Commission had failed to assess whether or not the total costs of delivering the door-to-door parcel service at a uniform tariff exceeded the level of subsidy it received.

${ }^{39}$ C-399/08 European Commission v Deutsche Post AG and others ECLI:EU:C:2010:481. See DC Bauer and G Muntean, "Case Note on European Commission v Deutsche Post AG et al." (2011) 4 European State Aid Law Quarterly 655; A Bartosch, "Clarification or Confusion? How to Reconcile the ECJ"s Rulings in Altmark and Chronopost”, (2003) European State Aid Law Quarterly 375.

${ }^{40}$ Bauer and Muntean, ibid, 669.
} 
${ }^{41}$ See Matos, supra n 36.

${ }^{42}$ Klasse, supra n 35, 50.

${ }^{43}$ An entrusted undertaking is any entity engaged in an economic activity, regardless of their legal status and the way in which the entity is financed (see e.g. Case C-41/90 Höfner and Elser v Macrotron [1991] ECR I-1979, para 21 and Joined Cases C-180/98 to C-184/98 Pavlov and Others [2000] ECR I-6451, para 74. Entrustment requires that the undertaking must discharge a public service assigned by an act of a public authority. See Case C-127/73 $B R T$ v SABAM [1974] ECR-313, para 20. ${ }^{44}$ Case T-442/03 SIC v Commission [2008] ECR II-1161, para 144; Joined Cases T-204/97 and T-270/97 EPAC v Commission [2000] ECR II-2267, paras 125-6; Case C-179/00 Merci Convenzionali Porto di Genova [1991] ECR5889, para 26.

${ }^{45}$ SIC v Commission, supra n 44, para 145; Olsen v Commission, supra n 26, para 239. In the CBI case, the General Court confirmed that Article 106(2) TFEU does not require an efficiency test such as that which is laid down in the fourth Altmark criteria; Case T-137/10 CBI v Commission ECLI:EU:T:2012:584, paras 295-300.

46 The 2005 SGEI Package - or so-called "Monti/Kroes Package" - consisted of a Decision and a Framework document. Both documents contained conditions under which compensation payments granted to entrusted undertakings with the provision of SGEI are compatible with the internal market "Community framework for State aid in the form of public service compensation" [2005] OJ C 297/4; "Commission Decision of 28 November 2005 on the application of Article 86(2) of the EC Treaty to State aid in the form of public service compensation granted to certain undertakings entrusted with the operation of series of general economic interest" [2005] OJ L 312/67). ${ }^{47}$ Commission, "Communication from the Commission on the application of the European Union State aid rules to compensation granted for the provision of services of general economic interest" [2012] OJ C8/4; Commission Decision (2012/21/EU) of 20 December 2011 on the application of Article 106(2) of the Treaty on the Functioning of the European Union to State aid in the form of public service compensation granted to certain undertakings entrusted with the operation of services of general economic interest [2011] OJ L7/3; Commission, "European Union framework for State aid in the form of public service compensation (2011)" (2012/C 8/03) [2012] OJ C8/15 (2012 SGEI Framework). 
clarification to the Member States for the assessment of public financing of SGEI. ${ }^{48}$ The Decision is a de facto block exemption for State aids below certain thresholds. Where the requirements of the Decision are satisfied, the public service compensation constitutes State aid but is considered to be compatible with the internal market and therefore no notification is required. ${ }^{49}$ For cases that fall outside the scope of the SGEI Decision, the compatibility of the payment must be assessed under the SGEI Framework. ${ }^{50}$ Where its criteria are satisfied, the payment still constitutes State aid but it is justified under Article 106(2). ${ }^{51}$

The requirements of the SGEI Framework only partially correspond with Article 106(2) jurisprudence. In line with recent case law, the Commission emphasises the market failure requirement in order to establish a genuine SGEI. ${ }^{52}$ The 2012 Framework also prescribes that the entrustment period is limited to the time necessary to recover the most significant assets, ${ }^{53}$ and prescribes methodologies for calculating the compensation payment. ${ }^{54}$ However, the Framework

\footnotetext{
${ }^{48}$ European Commission, "State aid: Commission adopts new rules on services of general economic interest (SGEI)” (2011), Press Release, IP/11/1579.

${ }^{49}$ For SGEIs in postal services and telecommunications, the compensation threshold was lowered from EUR 30 million to EUR 15 million per annum (Article 2(1)(a) of the Decision (2012/21/EU)). Undertakings providing SGEI have to be entrusted with the provision of the service by the Member State (Article 4). The scope of the Decision is then further limited by a 10 year entrustment period (under certain circumstances, where a longer period is required for the amortisation of the investment cost, this period can be extended) to reduce the negative impact on competition as the entrustment act can create a barrier to entry (Recital 12 and Article 2(2) of the Decision); see A Sinnaeve, "What's New in SGEI in 2012? - An Overview of the Commission's SGEI Package" (2012) 2 European State Aid Law Quarterly 347, 357. To avoid overcompensation of the entrusted service provider, the Decision limits the amount of compensation to the net costs, including a reasonable profit (Article 5(1)), in line with the third Altmark requirement.

${ }^{50}$ Note also the de minimis rules: Commission Regulation (EU) 360/2012 on the application of Articles 107 and 108 of the Treaty on the Functioning of the European Union to de minimis aid granted to undertakings providing services of general economic interest [2012] OJ L114/8.

512012 SGEI Framework, Recital 7. The 2012 SGEI Framework does not apply to SGEI in the land transport or public service broadcasting sectors, nor to providers of SGEI in difficulty; 2012 SGEI Framework, Recital 8 and 9. ${ }^{52}$ With regard to the Member States' discretion to actually judge whether the service is not provided through the market, the Commission's control is limited to the manifest error of assessment, 2012 SGEI Framework, Recital 13. 532012 SGEI Framework, Recital 17. This limitation is new compared to the 2005 SGEI Framework.

${ }^{54}$ The first and preferred method is the so-called "net cost avoided methodology". The second possible method is the "cost allocation methodology". Under the first methodology, the necessary net costs - or the net costs expected to be necessary - shall not exceed the difference between the net costs for discharging the services and the net cost or profits for the same provider without the obligation to provide such services (2012 SGEI Framework, Recital 25). For further guidance, the 2012 SGEI Framework refers in Recital 26 to the Annex IV of the Universal Service Directive (Directive 2002/22/EC) and to Annex I of the First Postal Directive (Directive 97/67/EC). The "cost allocation methodology" uses the difference between the costs and revenues for the calculation of the net costs necessary to provide the obligations (2012 SGEI Framework, Recital 28). For a discussion see D Geradin, "The New SGEI Package" (2012) 3 Journal of European Competition Law \& Practice 1. See generally Rodriguez and Storer, supra n 19.
} 
552012 SGEI Framework, Recital 18-19.

562012 SGEI Framework, Recital 39. For example, Member States can incorporate productive efficiency targets in the entrustment act and the level of compensation then depends on the extent to which the targets have been met, 2012 SGEI Framework, Recital 40 and 41.

${ }^{57}$ One should bear in mind that where an undertaking is entrusted with the provision of SGEI through a procurement procedure or where the level of compensation is based on the costs of a comparable efficient undertaking, the Altmark criteria will be satisfied and the payment will constitute a pure compensation payment and not State aid. In such a case, it would not be necessary to rely on the SGEI Framework.

${ }^{58}$ Rather than being based on a "typical and well-run undertaking" (as in the Altmark test), they must be based on objective and measurable criteria (2012 SGEI Framework, Recital 42). See Sinnaeve (n 49) 360. The General Court confirmed that Article 106(2) TFEU does not require an efficiency test such as laid down in the fourth Altmark criteria in CBI v Commission, supra n 45, paras 295-300.

${ }^{59}$ In comparison with Altmark, a tendering procedure is not required by established European case law SIC $v$ Commission, supra n 44, para 145; Olsen v Commission, supra n 26, para 239. See also Geradin, supra n 54, 6-7; EM Mestmäcker and H Schweitzer, Europäisches Wettbewerbsrecht (München, C.H. Beck, 3rd edn, 2014), 8.

${ }^{60}$ The different structure of the electricity sector in Member States as well as the different stages of liberalisation may have contributed to the fact that universal service is less defined in electricity, see Prosser, supra n 13, 186, 197, 205.

${ }^{61}$ In contrast, the Directive for electricity (Directive 2009/72/EC) contains more limited provisions on both universal service obligations and on compensation mechanisms. With respect to the former, the Directive requires that Member States ensure that all household customers and - at the discretion of Member States - SMEs shall enjoy universal service, defined as the "right to be supplied with electricity of a specified quality within their territory at reasonable, easily and clearly comparable, transparent and non-discriminatory prices" (Article 3(3)). On financial compensation, the Directive merely states that "financial compensation, other forms of compensation and exclusive rights which a Member State grants for the fulfilment" of any obligations "shall be done in a non-discriminatory and 
the relevant rules are contained in the Postal Services Directive (PSD) ${ }^{62}$ and Universal Service Directive (USD) respectively. ${ }^{63}$

\subsection{The scope of universal service in postal services and telecommunications}

As was discussed above, Member States enjoy a measure of discretion when defining SGEI (including USOs). This discretion can be reduced or displaced where USOs are specified by European secondary legislation. ${ }^{64}$ The degree to which discretion can be displaced depends on how precisely services are specified in secondary EU legislation. While Member States may impose USOs which go beyond those specified in the Directives, ${ }^{65}$ they may not use the compensation mechanisms contained within them to compensate service providers for these additional obligations. ${ }^{66}$ If Member States go further and expand the scope of USOs, they are subject to the State aid rules. ${ }^{67}$

For telecommunications, the USD requires that Member States ensure that services included in the scope of universal service are made available to all end-users irrespective of their geographical location at an "affordable price". ${ }^{68}$ In addition, with respect to ensuring the affordability of access, Member States may impose on operators to offer tariffs which depart

transparent way" (Article 3(6)). The 2003 Directive [Directive 2003/54/EC (repealed)] was identical. For a wider discussion see Harker, supra n 1, 52 - 64.

${ }^{62}$ Directive 97/67/EC of 15 December 1997 on common rules for the development of the internal market of Community postal services and the improvement of quality of service [1998] OJ L15/14, as amended by Directive 2002/39/EC [2002] OJ L176/21, as amended by Directive 2008/6/EC [2008] OJ/L52/3.

${ }^{63}$ Directive 2002/22/EC of 7 March 2002 on universal service and users' rights relating to electronic communications networks and services (Universal Service Directive) [2002] OJ L108/51, as amended by Directive 2009/136/EC [2009] OJ L337/11.

${ }^{64}$ Case C-206/98 Commission v Belgium [2000] ECR I-3509 para 45.

65 The USOs are defined in the Postal Service Directive, Article 3 Directive 97/67/EC, as amended by Directive 2002/39/EC, as amended by Directive 2008/6/EC and in the Universal Service Directive, Articles 3 - 9 Directive 2002/22/EC, as amended by Directive 2009/136/EC.

66 Directive 2002/22/EC, art 32; Directive 2008/6/EC, Recital 30.

${ }^{67}$ Directive 2008/6/EC, Recital 30. In doing so, Member States' discretion under the State aid regime is subject to a stricter proportionality standard (Sauter, supra n 15, 186-88); see also M Ross, "A healthy approach to services of general economic interest? The BUPA judgment of the Court of First Instance" (2009) 34 European Law Review 127, 136-8; Fiedziuk, supra n 23, 228; Klasse, supra n 35, 50-51.

${ }^{68}$ Directive 2002/22/EC, art 3(1). The relevant services are: access to a publicly available telephone network at a fixed location to a public communications network (Directive 2002/22/EC, as amended by Directive 2009/136/EC, art 4), a directory of users and a directory enquiry service (Directive 2002/22/EC, as amended by Directive 2009/136/EC, art 5), the provision of public pay telephones (Directive 2002/22/EC, as amended by Directive 2009/136/EC, art 6), and special measures for disabled end-users (Directive 2002/22/EC, as amended by Directive 2009/136/EC, art 7). 
${ }^{69}$ Directive 2002/22/EC, as amended by Directive 2009/136/EC, art 9(2).

${ }^{70}$ Directive 2002/22/EC, art 9(4).

${ }^{71}$ This includes letters up to 2 kilograms, packages up to 10 kilograms but may be increased up to 20 kilograms, and 20 kilograms for inbound parcels from other Member States and services for registered and insured items at a minimum of five working days per week, Directive 1997/67/EC, as amended by Directive 2008/6/EC, art 3.

${ }^{72}$ Directive 1997/67/EC, as amended by Directive 2008/6/EC, art 4; Directive 2002/22/EC, as amended by Directive 2009/136/EC, art 8. The historical position in postal services is different, as the postal incumbents in Member States retained exclusive rights over reserved services in order to facilitate the cross-subsidisation of universal service (this is explained in more detail in section D.2. below). However, the Third Postal Services Directive required the abolition of these exclusive rights, while at the same time putting in place new requirements for designation (modelled on those contained in the USD).

${ }^{73}$ For telecommunications, the Directive requires that Member States must "determine the most efficient and appropriate approach" which respects the principles of "objectivity, transparency, non-discrimination and proportionality", and "seek to minimise market distortions... whilst safeguarding the public interest", Directive 2002/22/EC, art 3(2). The PSD similarly refers to the requirements of "transparency, non-discrimination, proportionality, transparency and least market distortion”, Directive 97/67/EC, as amended by Directive 2008/136/EC, art 4(2).

${ }^{74}$ Directive 97/67/EC, as amended by Directive 2008/6/EC, art 4; Directive 2008/6/EC, Recital 23; Directive 2002/22/EC, as amended by Directive 2009/136/EC, art 8; Directive 2002/22/EC, Recital 14.

${ }^{75}$ Directive 2002/22/EC, art 8(2); Directive 97/67/EC, as amended by Directive 2008/6/EC, art 4(2).

${ }^{76}$ Directive 2002/22/EC, art 8(2). 
incumbent. ${ }^{77}$ This was because designation was limited to undertakings that were able to cover all of the national territory. An infringement procedure was launched, and the Court found that the provision in question, to the extent that it excluded operators who were unable to serve the whole of France, breached the principles contained in the USD. ${ }^{78}$ There are obvious tensions between the objective of cost effectiveness and the no a priori exclusion rule, especially in relation to economies of scale and scope. ${ }^{79}$ It is clear from the approach of the Commission and the Court, however, that the no a priori exclusion rule takes precedence. ${ }^{80}$

Various problems have been identified concerning designation, especially in telecommunications. A number of countries have been slow to put in place legislation for the designation of USPs, much to the chagrin of the Commission. ${ }^{81}$ Despite the principles outlined above, and the increased formalisation by Member States of the designation process in domestic legislation, in practice the incumbents are appointed as USPs in the vast majority of cases in both

\footnotetext{
${ }^{77}$ Commission, "European Electronic Communications Regulation and Markets 2005 (11th Report)", (Staff Working Document) Volume I, SEC(2006) 193, 143. Infringement proceedings were also launched against Finland in 2005. In that case, the relevant legislation appeared to specify that the operator designated as USP would be the company either with significant market power or having the largest market share in the region. The case did not come before the Court (ibid, 269).

${ }^{78}$ Case C-220/07 Commission v France [2008] ECR I-95, paras 32 - 33.

${ }^{79}$ BEREC, "Report on Universal Service - reflections for the future" (2010), 17 http://berec.europa.eu/eng/document_register/subject_matter/berec/reports/187-berec-report-on-universal-servicereflections-for-the-future accessed 3 August 2016.

${ }^{80}$ In another case, which resulted in infringement proceedings against Spain, one firm expressed an interest in providing a directory enquiries service. The Spanish rules excluded from consideration firms who were only interested in offering one unique element of the USOs, and hence the firm was not considered. Despite attempting to justify its approach on the ground of cost-effectiveness, the Commission held that the rules for designation were in breach of the principles of the USD. Letter of formal notice from the European Commission to Spain (27.06.2007), "Designation and financing of universal service"; European Commission, "New round of infringement proceedings under the EU telecom rules: What are the issues?", (2007) MEMO/07/2005; The Commission closed the case after Spain had changed its national legislation, European Commission, "Telecoms: Commission requests information from Spain on new charge on operators; closes infringement case on universal service", Press Release, IP/10/322, 18 March 2010.

${ }^{81}$ Commission, "Progress Report on the Single European Electronic Communications Market (15th Report)", (Staff Working Document) Volume I, SEC(2010) 630 final, 57-58.
} 
telecommunications ${ }^{82}$ and postal services. ${ }^{83}$ This may be the result of a lack of incentives for new entrants to apply for designation, even if the process is open to them, a point made by BEREC:

“...[I]t appears that the number of competitors having the technical and financial standing required for an USP designation is very limited, which adds to what can be described as an inherent reluctance of market players to compete for being designated as bearers of obligations... under the regulatory framework" ${ }^{84}$

For postal services, a recent survey of the USP designation points to a failure of most Member States to consider introducing some element of contestability in universal service provision, using instead "universal service designation to continue some remnant of the former legal privileges of the public postal operators". 85

\subsection{Deciding whether to compensate - "net costs" and "unfair burden"}

The relevant legislation on telecommunications and postal services contain broadly similar principles on the implementation and design of compensation mechanisms. ${ }^{86}$ Before such arrangements may be made, the relevant regulator must be satisfied that the provision of universal service represents an "unfair burden" on the designated undertaking(s) based on a "net

\footnotetext{
${ }^{82}$ At that time, in 2005, it was only in Estonia that a tender process resulted in the designation of a new entrant as USP; in Belgium and the Czech Republic, elements of the service were provided by entrants alongside the incumbent, Commission, "European Electronic Communications Regulation and Markets 2006 (12th Report)", COM(2007), 155 final, 17. According to a 2010 Report, published by the Body of European Regulators for Electronic Communications (BEREC), eight out of 27 BEREC countries used the tender process to designate the universal service provider, BEREC, supra n 79, 30-33.

${ }^{83}$ AK Dieke et al., "Main Developments in the Postal Sector (2010-2013)" (Study for the European Commission, Directorate General for Internal Market and Services) (2013), 137, http://ec.europa.eu/internal_market/post/doc/studies/20130821_wik_md2013-final-report_en.pdf accessed 3 August 2016.

${ }^{84}$ BEREC, supra n 79, 31-32.

${ }^{85}$ Dieke et al., supra n 83, 137. Malta, Sweden and Germany are exceptions. The latter has not designated any operator at all since 2008, Harker et al., supra n 1, 37. In Estonia, Luxemburg, Poland, Romania and Sweden universal service is also provided without relying on a designated USP, European Commission, "Implementation of the EU regulatory framework for electronic communications - 2014" (Commission Staff Working Document) SWD(2014) 249 final, 17.

${ }^{86}$ For postal services, alongside the abolition of the "reserved market", new rules on the compensation mechanism were promulgated in 2008 (Directive 97/67/EC, as amended by Directive 2008/6/EC, art 7(1)), which largely reflect those already in existence for telecommunications that are contained in the Universal Service Directive (Directive 2002/22/EC).
} 
cost" calculation of the provision..$^{87}$ The meaning of "unfair burden" is not elaborated upon in either the USD or PSD.

The calculation of net cost, upon which an assessment of unfair burden depends, is by no means straightforward. ${ }^{88}$ When assessing net costs, account should be had to any "market benefit" or "intangible benefits" which accrue to the USP. ${ }^{89}$ The calculation of attributable costs includes identified services or users which can only be provided or served at a loss or under cost conditions falling outside normal commercial standards. A calculation of the net costs of each aspect of universal service is to made separately in order to avoid any "double counting" of any direct or indirect benefits and costs. Notwithstanding the principles above, both the USD and PSD do not define what is meant by "unfair", and several alternative approaches have been suggested, including: whether the net costs of the USO exceed those costs which would be involved in setting-up a compensation mechanism, the inability of the USP to make a normal economic profit (the requirement for a "reasonable profit" is recognised in the PSD) ${ }^{90}$ or where the profitability of the USP differs significantly from its competitors. ${ }^{91}$

Neither the USD nor the PSD specify or give examples of what is an intangible benefit. Recital 20 of the USD merely states that such benefits should be an "estimate in monetary terms, of the indirect benefits that an undertaking derives by virtue of its position as [a] provider of universal service". In a survey of BEREC members, a number of examples of intangible benefits were

\footnotetext{
${ }^{87}$ Directive 2002/22/EC, art 12(1) in accordance with Annex IV, Part A; Directive 97/67/EC, as amended by Directive 2008/6/EC, art 7(3) in accordance with Annex I, Part B.

${ }^{88} \mathrm{Net}$ costs are defined as the difference between the USP's net costs operating with the universal service obligations and operating without them, Directive 2002/22/EC, Annex IV, Part A; Directive 97/67/EC, as amended by Directive 2008/6/EC, Annex I, Part B.

${ }^{89}$ Directive 2002/22/EC, art 12(1) in accordance with Annex IV, Part A; Directive 97/67/EC, as amended by Directive 2008/6/EC, art 7(3) in accordance with Annex I, Part B.See also Commission, "Assessment Criteria for National Schemes for the Costing and Financing of Universal Service in telecommunications and Guidelines for the member States on Operation of such Schemes", $\operatorname{COM}(96) 608$ final. For a discussion of different methodologies used in postal services to determine whether or not a financial burden is "unfair", see Frontier Economics, "Study on the principles used to calculate the net costs of the postal USO: A Report prepared for the European Commission" (2013), 123-36 http://ec.europa.eu/internal_market/post/doc/studies/2012-net-costs-uso-postal_en.pdf accessed 3 August 2016.

${ }^{90}$ Directive 97/67/EC, as amended by Directive 2008/6/EC, Annex I, Part B. For a discussion see F Boldron et al., "A Dynamic and Endogenous Approach to Financing the USO in a Liberalized Environment", in MA Crew and PR Kleindorfer (eds), Progress in the competitive agenda in the postal and delivery sector (Cheltenham, Edward Elgar, 2009).

${ }^{91}$ Frontier Economics, supra n 89, 123-36.
} 
gathered from national regulatory authorities (NRAs). These included: the benefits of geographical ubiquity, which arises where a customer moves from an area served only by the USP to another area where there are new entrants; the "life-cycle effect" benefit, relating to a customer who it is currently unprofitable to serve who might become profitable in the future; and benefits resulting from brand enhancement and corporate reputation..$^{92}$ As BEREC observes, estimating and quantifying the intangible benefits is likely to "prove extremely difficult" in practice. $^{93}$

Once the net costs have been calculated, and these are judged to be an "unfair burden", the Member States must then decide, upon the request of the designated undertaking(s), how to compensate. This compensation can be drawn directly from public funding, or by sharing the net costs between market participants. ${ }^{94}$ Such a sharing mechanism must be administered by a body independent of the beneficiaries of the scheme, ${ }^{95}$ respecting the principles of transparency, nondiscrimination, and proportionality. ${ }^{96}$ For telecommunications, Member States must also respect the principle of "least market distortion", ${ }^{97}$ and have the discretion to exempt new entrants "which have not yet achieved any significant market presence". 98

The net cost calculation and establishment of an unfair burden appears to be a complicated and time-consuming process in telecommunications. Due to various administrative delays, court proceedings, delays in contributions, or updates of net cost calculation methodologies, compensation schemes have not been widely employed by Member States. ${ }^{99}$

\footnotetext{
92 BEREC, supra n 79, 35-36. For a similar study in respect of postal services, see Frontier Economics, supra n 89 , 109-22.

${ }^{93}$ For some examples of methodologies used by the national regulatory authorities, see BEREC, supra n 79, 36-38.

${ }_{94}$ Directive 97/67/EC, as amended by Directive 2008/6/EC, art 7(3); Directive 2002/22/EC, art 13(1).

${ }^{95}$ Directive 2002/22/EC, art 13(2), which goes on to specify this should be either the NRA or a body supervised by it; Directive 97/67/EC, as amended by Directive 2008/6/EC, art 7(4). The PSD also refers to the requirement of supervision by the NRA in the calculation of net costs, Directive 2008/6/EC, Recital 29.

${ }^{96}$ Directive 97/67/EC, as amended by Directive 2008/6/EC, art 7(5); Directive 2002/22/EC, art 13(3).

${ }^{97}$ Directive 2002/22/EC, Recital 23.

${ }^{98}$ Directive 2002/22/EC, Recital 21.

${ }^{99}$ In 2009, compensation mechanisms were only in place and activated in France, Czech Republic, Italy, Spain, Romania, Latvia and in Belgium for social tariffs only, Commission, supra $\mathrm{n}$ 81, 58. As is discussed below, the Belgian compensation mechanism for social tariffs was later challenged by the European Commission.
} 
The most important case on the principles which must be followed by Member States in compensating USPs is Commission v Belgium. ${ }^{100}$ The USO in question related to "social tariffs", i.e., discounts which were available to consumers on low incomes and with special needs. All operators, the incumbent and entrants alike, were required to offer these tariffs to such customers. A compensation scheme was set up whereby payments were made to any operator which carried a disproportionate number of social tariff consumers relative to its market share. Compensation was calculated at a flat-rate for all operators and was automatic - there was no additional need to demonstrate that the number of social tariffs carried by an individual operator imposed an "unfair burden", and the net cost of serving a social tariff customer was assumed to be the same for all operators.

The Court found that the automatic nature of the scheme breached the Directive's requirement that an undertaking had to be found to bear an unfair burden before compensation mechanisms could be put in place. ${ }^{101}$ The Court held that a net cost is not per se an unfair burden:

“...[T]he unfair burden which must be found to exist by the national regulatory authority before any compensation is paid is a burden which, for each undertaking concerned, is excessive in view of the undertaking's ability to bear it, account being taken of all the undertaking's own characteristics, in particular the quality of its equipment, its economic and financial situation and its market share". ${ }^{102}$

For the purposes of this assessment, the NRA had to lay down "general and objective criteria" taking into account the undertaking's characteristics, and must carry out "an individual assessment of the situation of each undertaking concerned". ${ }^{103}$ The Court also held that the assessment of the net cost for the undertaking must also include intangible benefits, in line with

\footnotetext{
100 Case C-222/08 Commission v Belgium [2010] ECR I-9017. See also Case C-389/08 Base and Others [2010] ECR I-9073, a preliminary reference procedure covering the same ground. See also Case C-384/99 Commission $v$ Belgium [2000] ECR I-633.

${ }^{101}$ Commission v Belgium, ibid, para 58. In Commission v France, a compensation scheme set up to compensate the incumbent was unnecessary given that the incumbent held a near monopoly over the market (Case C-146/00 Commission v France [2001] ECR I-9767, paras 25-30).

102 Commission v Belgium, ibid, para 49. Emphasis added.

103 Ibid, para 50.
} 
the requirements of the Directive. ${ }^{104}$ It rejected the Belgium Government's argument that where USOs applied to all operators, the benefits would be the same for all of them. ${ }^{105}$

\section{Conclusions}

As we have demonstrated, the provisions which exist for compensating undertakings for the costs of universal service are complex and cumbersome. This would appear to explain their limited take-up by Member States. This may further explain why, in telecommunications, the ex ante system of compensation has been usurped by the State aid regime, especially in relation to the provision of universal service in broadband services. However, the State aid regime has been significantly reconfigured in recent years to promote contestability in the assignment of public service obligations.

\section{Balancing universal access and liberalisation: case studies in broadband and postal services}

In this section, we analyse recent developments in securing universal service in broadband and the letter collection and delivery markets. It is in these two sectors where we see the most pronounced tensions between the achievement of USOs and liberalisation, albeit for different reasons. In telecommunications we witness the most technological change, and liberalisation is the most advanced. However, for broadband, the regime for securing universal access under the USD has largely been usurped by the use of State aid, with important consequences in terms of the Commission's supervisory powers and the formal protection of USOs. Furthermore, while state support for the rolling-out of significant broadband infrastructure investment may be seen as necessary to secure universal access to vital communications services, this objective is subject to a number of limiting principles which give precedence to securing and maintaining effective competition. For postal services, the model of achieving universal service, as originally envisaged under the EU legislation, was one where the incumbent could sustain cross-subsidies

\footnotetext{
104 Ibid, para 84.

105 Ibid, para 69.
} 
because it had exclusive rights over certain market sectors. These rights were gradually withdrawn, with full competition being introduced across the EU between 2010 and 2012. Alongside this, the rules on compensation were also reformed to the extent that Member States were encouraged to ensure that there was a level of contestability in universal service provision. In the collection and delivery of letters, our focus here, demand has been declining for a number of years, while at the same time incumbents have seen a gradual reduction in their ability to subsidise USOs. In this sector, there is little use of compensation mechanisms, despite the claims that universal service is being placed in jeopardy by new entrants and their so-called 'cherrypicking' of the most profitable consumers. The emphasis thus far has been on the incumbents achieving efficiency gains. ${ }^{106}$

\section{Broadband and its inclusion within the USOs}

There is no doubt that, in a sector such as communications where technological progress and demand conditions evolve rapidly, services which might have been seen as essential until only recently can become obsolete. There is no better example than the provision of public payphones which are only used by a very small percentage of end-users, yet are very expensive to maintain. ${ }^{107}$ It is hardly surprising, therefore, that bringing new services within an EU-wide definition of universal service has be approached with considerable caution by both Member States and the Commission. In some cases, such as mobile services, the answer is straightforward; the market is the best route to maximising both ubiquity and affordability, without the need for any form of state intervention. ${ }^{108}$

The position within broadband is quite different, where it is clear that neither national governments nor the Commission believe that universal broadband coverage will be achieved by

\footnotetext{
106 See, for example, Dieke, supra n 83, 220-22.

107 Some Member States have already withdrawn the obligation to provide public payphones as part of the USO (Belgium, Finland, the Netherlands, Latvia, Cyprus, Denmark, Estonia, Germany, Luxembourg, Poland, Romania and Slovakia), European Commission, "Implementation of the EU regulatory framework for electronic communication - 2015" (Commission Staff Working Document) SWD(2015) 126 final, 22.

${ }^{108}$ European Commission, "Universal service in e-communications: report on the outcome of the public consultation and the third periodic review of the scope in accordance with Article 15 of Directive 2002/22/EC",

(Communication) COM(2011) 795 final, 8-9, 12.
} 
the market alone. ${ }^{109}$ This is particularly the case when it comes super-fast broadband - so-called "next generation access" (NGA) - the rolling-out of which requires substantial upgrading and replacement of existing telecommunications infrastructure. ${ }^{110}$ An obvious solution to this problem would be to use the existing sectoral regime by including a minimum level of broadband services within the definition of USOs, triggering - where appropriate - the use of compensation mechanisms for the investment necessary to secure coverage in areas that would otherwise be unprofitable to serve.

Since the original USD, Member States have been required to ensure that all users connected at a fixed location have access to data communications "at data rates that are sufficient to permit functional internet access, taking into account prevailing technologies used by the majority of subscribers and technological feasibility". ${ }^{111}$ In contrast to the original Directive which specified, for the purposes of imposing a USO, functional internet access as a single narrowband connection at a maximum data rate, ${ }^{112}$ the 2009 amending Directive removed any reference to a defined data rate, ${ }^{113}$ making clear that Member States were to have flexibility in defining a minimum level of internet access, "taking due account of specific circumstances in national markets, for instance the prevailing bandwidth used by the majority of subscribers in that Member State, and technological feasibility, provided that these measures seek to minimise market distortion". ${ }^{114}$ This was a significant change since Member States, while always being free to impose more onerous universal service obligations than those specified in the USD, were not permitted to include these within any compensation mechanism involving specific undertakings. ${ }^{115}$ The situation now allows Member States to include broadband access within the

\footnotetext{
${ }^{109}$ F Chirico and N Gaál, "A Decade of State Aid Control in the Field of Broadband” (2014) 13 European State Aid Law Quarterly 28, 28-29.

${ }^{110}$ For an overview see A Kliemann and O Stehmann, "EU State Aid Control in the Broadband Sector - The 2013 Broadband Guidelines and Recent Case Practice” (2013) 12 European State Aid Law Quarterly 493, 495-7.

111 Directive 2002/22/EC, art 4(2).

112 Ibid, Recital 8. A single narrowband network connection referred to a data rate of $56 \mathrm{kbit} / \mathrm{s}$. Member States were allowed to deviate and lower the data rate where necessary.

113 Directive 2009/136/EC.

114 Ibid, Recital 5.

115 Directive 2002/22/EC, art 32. The wording of this provision was unchanged by the 2009 amending Directive. However, Directive 2009/136/EC, Recital 5 makes clear that where an expansion of minimum internet access covered by USO within a Member State results "in an unfair burden on a designated undertaking, taking due account of the costs and revenues as well as the intangible benefits resulting from the provision of the services concerned, this may be included in any net cost calculation of universal obligations".
} 
${ }^{116}$ Directive 2009/136/EC, Recital 5 makes clear that alternative financing methods may also be enacted. The Commission confirmed that compensation for the infrastructure and wholesale provision of basic broadband in the form of State aid did not breach the original USD, Decision N381/2004 Haut débit en Pyrénées-Atlantiques [2004] Press Release IP/04/1371; Decision N382/2004 Haut débit en Limousin - DORSAL [2005] Press Release IP/05/530. ${ }^{117}$ Belgium, Spain, Finland, Croatia, Malta, Sweden and Latvia (only for disabled end-users) have included broadband at different broadband speeds within the scope of universal service. Latvia, Slovenia and the United Kingdom are discussing whether or not to extend the scope of USO by including broadband, European Commission, supra $\mathrm{n}$ 107, 22. However, there are reports the European Commission is now proposing to include broadband access in the scope of universal service, C Stupp, "Broadband internet access will become a legal right under new EU telecoms rules", EurActiv.com, 29 July 2016, http://www.euractiv.com/section/innovationindustry/news/broadband-internet-access-will-become-a-legal-right-under-new-eu-telecoms-rules/?nl_ref=17987440 accessed 3 August 2016.

${ }^{118}$ European Commission, "Universal service in e-communications: report on the outcome of the public consultation and the third periodic review of the scope in accordance with Article 15 of Directive 2002/22/EC", (Communication) COM(2011) 795 final, 12.

${ }^{119}$ Subject to some limited exceptions, it appears that the majority of Member States are pursuing increasing broadband access outside of the sectoral rules, see BEREC, supra n 79, 59.

${ }^{120}$ European Commission, “A Digital Agenda for Europe” (Communication) COM(2010) 245 final. 
The DAE contains a number of ambitious broadband targets, ${ }^{121}$ the achievement of which will involve considerable investment in infrastructure, both private and public. The key danger of leaving infrastructure investment merely to private firms is that high-speed broadband access will be "concentrated in a few high-density zones with significant entry costs and high prices". ${ }^{22}$ Furthermore, relying only upon the private sector will result in under-investment since the positive externalities resulting from network expansion will not be captured, particularly the economic growth which it can facilitate. Such "market failures" can be corrected somewhat by public sector investment and, for this reason, the DAE seeks to impose on Member States an obligation to draw-up national broadband plans which should include the use of "public financing in line with EU competition and state aid rules", in particular avoiding market distortions. ${ }^{123}$

In order to complement the general guidelines on State aids (explained in section C.1. above), the Commission has attempted to enunciate in detail the principles it will apply to broadband in a set of Guidelines first issued in 2009, and then subsequently updated in 2013, ${ }^{124}$ the latter reflecting the priorities of the DAE, particularly the need for increased public investment in NGA broadband. ${ }^{125}$

The Guidelines recognise, on the one hand, that the DAE targets cannot be achieved without the support of public funds, while cautioning that State aid should only be complementary to, and not a substitute for, the investments of market players, limiting as far as possible the risk of "crowding out of private investments". ${ }^{126}$ It notes the need to go beyond mere market failures; markets may produce outcomes which are efficient but are otherwise "unsatisfactory from a

\footnotetext{
${ }^{121}$ The first of these - securing the availability of basic broadband to all European citizens - was achieved ahead of schedule in 2013. The focus now is how to provide fast and ultra-fast broadband by 2020 to all and half of the European households respectively. European Commission, "100\% basic broadband coverage achieved across Europe - EU target achieved ahead of schedule. Next stop is fast broadband for all.” (2013), Press Release, http://europa.eu/rapid/press-release_IP-13-968_en.htm accessed 3 August 2016.

${ }^{122}$ European Commission, supra n 120, 19.

${ }^{123}$ Ibid, 21.

${ }^{124}$ European Commission, "EU Guidelines for the application of State aid rules in relation to the rapid deployment of broadband networks" [2013] OJ C25/1.

${ }^{125}$ The cost of the provision of internet speeds of 30 Mbps are estimated to be nearly EUR 60 billion and to provide at least half of the European households with ultra-fast internet (100 Mbps) may be up to EUR 268 billion, European Commission, supra n 124, para 2.

${ }^{126}$ Ibid, para 4.
} 
${ }^{127}$ Ibid, para 5.

${ }^{128}$ Ibid, para 6.

${ }^{129}$ In the case of broadband projects, the state aid measures may be compatible with the internal market, if the measure promotes the economic development of areas with an abnormally low standard of living or high unemployment rate (Article 107(3)(a) TFEU) or in which the aid enhances the development of certain economic activities or certain economic areas and does not have a negative effect on the European Union (Article 107(3)(c) TFEU).

${ }^{130}$ European Commission, supra n 124, paras 30-54.

${ }^{131}$ Ibid, supra n 124, paras 51, 78; See Kliemann and Stehmann, supra n 110, 512-13.

${ }^{132}$ European Commission, supra n 124, para 78(c); Member States are also required to respect the principle of technological neutrality with no a priori preference given to one type of technology over another, European Commission, supra n 124, para 78(e).

${ }^{133}$ Kliemann and Stehmann, supra n 110, 511.

${ }^{134}$ F Chirico and N Gaál, "State aid to broadband: primer and best practices" (2011) Competition Policy Newsletter, Number 1, 50, 55 http://ec.europa.eu/competition/publications/cpn/2011_1_10_en.pdf accessed 3 August 2016. Even where this requirement is not met, aid may be lawful under Article 106(2) (see Decision N196/2010 Establishment of a Sustainable Infrastructure Permitting Estonia-wide Broadband Internet Connection (EstWin Project) [2010]. 
There has been a considerable increase in the number of broadband State aid cases since the first one was notified in 2003. ${ }^{135}$ Between December 2003 and August 2009, the Commission processed only 47 cases, whereas between the adoption of the 2009 Guidelines and mid-February 2014, it decided 85 broadband cases, clearing $82 .{ }^{136}$ In terms of the volume of State aid involved, this increased sharply from an annual average of $€ 30-55$ million in 2003-2005, to almost $€ 2$ billion per year from 2010 and $€ 6$ billion in $2012 .{ }^{137}$

The vast majority of cases appear to be notified and cleared under the State aid regime, but there remains a residual category for cases which may escape the State aid regime altogether because the Member State seeks to rely upon the Altmark criteria. ${ }^{138}$ Such cases are dealt with briefly in the Guidelines. ${ }^{139}$ The most significant case to date is Réseau à très jait débit en Hauts-deSeine.$^{140}$ Here, following a competitive tendering process, the French authorities awarded a subsidy of $€ 59$ million over 25 years to a consortium to build a high-speed broadband network in the Hauts-de-Seine department, an area bordering Paris. Following a voluntary notification by France, the Commission determined that the payment did not constitute State aid, ${ }^{141}$ a decision which was contested by a number of competitors before the General Court. ${ }^{142}$ The Court upheld the Commission's decision that all four Altmark critera were met. The first of these, the existence of a SGEI, was present since there was evidence of a "market failure" in so far as, despite being a relatively densely populated area, there was evidence to suggest that the commercial operators would not have the incentives to serve all users in the area with high-speed broadband. The

\footnotetext{
135 Decision N282/2003 Cumbria Broadband-Project ACCESS [2003].

136 European Commission, "Commission decision on State aid to broadband" (2016) http://ec.europa.eu/competition/sectors/telecommunications/broadband_decisions.pdf accessed 3 August 2016. For a detailed discussion of the cases, see Kliemann and Stehmann, supra n 110.

${ }^{137}$ Chirico and Gaál, supra n 109, 30. This amounts to 10 per cent of the total State aid granted (ibid, 31). This actual amount may be higher since the notification requirement does not apply, in theory at least, to investment which meets the Altmark criteria.

138 According to Kliemann and Stehmann, supra n 110, 504 only three cases have been considered by the Commission under Article 106(2), all concerning France. Of course, there are other categories of cases where public investment does not amount to State aid (e.g. where the market investor principle can be demonstrated with respect to the aid, European Commission, supra n 124, paras 16 and 17.

139 European Commission, supra n 124, paras 18-27.

140 Decision $N$ 331/2008 Réseau à très jait débit en Hauts-de-Seine [2009] C(2009) 7426 final.

${ }^{141}$ Strictly speaking, there is no requirement to notify, but it appears that France opted to do so for legal certainty reasons, Kliemann and Stehmann, supra n 110, 504.

142 Case T-79/10 Colt Télécommunications France v Commission ECLI:EU:T:2013:463; Case T-258/10 Orange v Commission ECLI:EU:T:2013:471; Case T-325/10 Iliad and Others v Commission ECLI:EU:T:2013:472.
} 
General Court confirmed that the presence of a market failure, which was an "objective concept", ${ }^{143}$ was a necessary condition for finding a service to fall within the SGEI definition. ${ }^{144}$ It also held that the presence of universal service with respect to basic broadband, did not demonstrate the lack of a market failure on the high-speed broadband market. ${ }^{145}$ The Court also rejected the arguments of the commercial operators that over-compensation would occur, contrary to the third Altmark criterion, merely because the scheme is designed to use crosssubsidies from profitable consumers to reduce the costs of serving those who are unprofitable. ${ }^{146}$

\subsection{Conclusions}

The approach of the European Commission and the majority of the Member States raises the question of why they prefer using State aid procedures instead of including broadband in the scope of universal service under the USD and then, if necessary, compensate the universal service provider.

All Member States have developed national broadband plans for fulfilling the goals of the DAE, some going even further. Some countries focus on improving broadband access in rural areas, while others that have sufficient coverage in all parts of their country may focus on the availability of NGA broadband. ${ }^{147}$ This differentiated approach certainly tells against the adoption of a USO at the EU level with prescribed minimum broadband speeds. On the other hand, the requirement as it now stands in the USD does leave Member States with a considerable amount of discretion when it comes to defining a universal level of broadband access suitable to the relevant markets and demand conditions. Furthermore, for national governments, invoking the provisions of the USD with respect to both prescribing and, where necessary, compensating

\footnotetext{
${ }^{143}$ Colt, supra n 142, para 158.

${ }^{144} \mathrm{Ibid}$, para 153. As has been pointed out elsewhere, this is an important development since it limited the discretion member states have to determine whether there is the necessity for a SGEI, E Szyszczak, "Services of General Economic Interest and State Measures Affecting Competition" (2014) 5 Journal of European Competition Law \& Practice, 508, 514.

${ }^{145}$ Colt, supra n 142, para 161.

${ }^{146}$ Ibid, paras 185-6. The Court of Justice ruled inadmissible the competitors challenge to the General Court's judgment Case C-621/13P Orange v Commission ECLI:EU:C:2015:114; Case C-624/13P Iliad and Others v Commission ECLI:EU:C:2015:112.

${ }^{147}$ For detailed information on national broadband plans and their realisation, see European Commission, supra $\mathrm{n}$ 120; BEREC, supra n 79.
} 

supervisory jurisdiction under Article 108(3). ${ }^{148}$ However, the use of the USD procedures are complex and may give rise to a level of legal uncertainty which itself may result in sub-optimal levels of investment. A USO provider must first be designated, and it will only be compensated where the NRA determines that it bears an unfair burden. As was discussed in section C.2., this does not simply mean net costs; in each case an individual assessment is required and what is an unfair burden for one undertaking may not be for another operator (this assessment depends on the firm's size and market share, its equipment, economic and financial situation, and any intangible benefits of being the USP). ${ }^{149}$ As the rules under the USD derive from the Altmark criteria, the level of compensation is strictly limited to the provision of USO, i.e. the USP can only be compensated for infrastructure investment which could not be supported by the market. ${ }^{150}$ This methodology no doubt creates uncertainty for a potential USP, which is likely to impact disproportionately on new entrant firms who might otherwise be willing to invest in infrastructure, rather than merely relying upon access to the incumbent's network. Indeed, one of the key benefits of relying on the State aid regime is the extent to which it opens avenues for infrastructure competition, especially in relation to the deployment of NGA broadband, which can no longer be supported only by the incumbent's legacy networks. ${ }^{151}$ By way of contrast, a reliance on the incumbent provider is likely to create significant barriers to entry, and merely extend incumbency advantages into new broadband service markets.

\section{Postal services}

The concept of universal service in the postal sector has a long history. Historically, the norm throughout the EU was to have a monopoly postal provider charged with an obligation to fulfil universal service at a uniform price. From the early 1990s, however, this model of universal service delivery was gradually dismantled, with the abolition of exclusive rights for incumbents

\footnotetext{
${ }^{148}$ Interestingly, Chirico and Gaál argue that the principles established in the Guidelines and the underlying case law are now so clear and consistently applied that a State aid exemption for broadband should now be put into place, Chirico and Gaál, supra n 109, 36.

${ }^{149}$ Commission v Belgium, supra n 101.

${ }^{150}$ European Commission, supra n 124, para 26; L Papadias, F Chirico and N Gaál, "The new State Aid Broadband Guidelines: not all black and white" (2009) Competition Policy Newsletter, Number 3, 17, 20 http://ec.europa.eu/competition/publications/cpn/2009_3_3.pdf accessed 3 August 2016.

${ }^{151}$ For a discussion see Kliemann and Stehmann, supra n 110, 498.
} 
from 2012 onwards. Alongside this there has been significant changes in demand, especially a steep decline in the volume of letters, as customers and businesses increasingly use electronic forms of communication. ${ }^{152}$ While new entry in the postal services market may have played a significant role in securing greater efficiency, it has also posed a challenge to the sustainability of universal service. Competition has come from firms who have only entered the most profitable segments of the market, such as bulk mail, business to business communications, and the growing parcel delivery sector. ${ }^{153}$ This poses particular difficulties for incumbents, whose ability to cross-subsidise USOs has been eroded.

\subsection{Liberalisation of postal services and the protection of USOs: reconciling the two objectives}

The liberalisation of postal services began with the publication of a Green Paper in 1992 which proposed to protect and finance USOs by granting exclusive rights to the incumbents with respect to specific reserved services. ${ }^{154}$ This was followed in 1994 by a Council resolution inviting the Commission to come forward with legislative proposals to include a definition of a minimum level of universal service and, in order to ensure "the economic and financial viability" of the provision of universal service, the definition of "a sector of appropriate dimensions which may be reserved for universal service providers". ${ }^{155}$ The First Postal Directive ${ }^{156}$ in 1997 defined universal service as "the permanent provision of a postal service of specified quality at all points in their territory at affordable prices for all users", ${ }^{157}$ prescribing the minimum levels of service

\footnotetext{
${ }^{152}$ In the UK, the volume of letter mail has dropped by $28.2 \%$ since 2008. Despite the loss in volume, the prices for standard-sized letter mail are cheaper than in other European countries, Ofcom, "International Communications Market Report" (2014), $311 \mathrm{http} / / /$ stakeholders.ofcom.org.uk/binaries/research/cmr/cmr14/icmr/ICMR_2014.pdf accessed 3 August 2016. The financial crisis and the recession has left its scars, Dieke et al., supra n 83, 168. 153 The parcel market has grown over the last years (23.4\% between 2008 and 2013), mainly because of an increasing popularity of e-commerce leading to a growth of the business to consumer segment of the parcel market. The revenues in the parcel market are also higher than in the letter market. In 2014, Royal Mail's domestic parcel revenue market share was 31\%, Business, Innovation and Skills Committee, "Competition in the postal services sector and the Universal Service Obligation" (Ninth Report of Session 2014-15), para 56, http://www.publications.parliament.uk/pa/cm201415/cmselect/cmbis/769/769.pdf accessed 3 August 2016.

${ }^{154}$ Commission, "Green Paper on the Development of the Single Market for Postal Services" (Communication) $\operatorname{COM}(91) 476$ final.

${ }^{155}$ Council Resolution of 7 February 1994 on the development of Community postal service [1994] OJ C 48/3.

${ }^{156}$ Directive 97/67/EC.

${ }^{157}$ Ibid, art 3(1).
} 
Member States should seek to protect. ${ }^{158}$ At the same time, it stipulated the limitations of reserved services, and set out a number of deadlines to be met in the gradual reduction of their scope, "taking into account the financial equilibrium of the universal service provider(s)". ${ }^{159}$

In 2002, the Commission reported on the effect of liberalisation of universal service, painting a very positive picture of the situation in all of the Member States. ${ }^{160}$ Not only were the minimum requirements of the Directive being met, in many countries they were being exceeded significantly. Furthermore, while the Directive only required universal service at "affordable prices", ${ }^{161}$ the Commission reported that "the uniform tariff remains a cornerstone of universal service in all Member States (even if not a regulatory requirement in all of them)". ${ }^{162}$ However, there was evidence that the financial stability of USPs was in question: in seven Member States, provisions for compensation mechanisms were in place, although at that time only Spain had plans to activate a fund. ${ }^{163}$ All in all, the Commission concluded that universal service was "not at risk". ${ }^{164}$ This finding was hardly surprising given the report had been overtaken by the adoption of Second Postal Service Directive, ${ }^{165}$ which laid down deadlines for the significant reduction in the scope of reserved services in 2003 and 2006 while at the same time leaving the universal service requirements substantially the same. ${ }^{166}$

Although the clear endpoint was the removal of reserved markets, there was evidence of some nervousness over the sustainability of USOs, the Directive requiring the Commission complete an assessment by the end of 2006 of the "impact on universal service of the full accomplishment of the postal internal market". ${ }^{167}$ In fulfilling that requirement, the Commission announced a

\footnotetext{
${ }^{158}$ Directive 97/67/EC, art 3(3).

159 Ibid, art 7(3).

${ }^{160}$ Commission, "Report from the Commission to the European Parliament and the Council on the application of the Postal Directive (97/67/EC Directive)" COM(2002) 632 final, 16-19.

${ }^{161}$ Directive 97/67/EC, art 3(1).

162 Commission, supra n 160, 17.

163 Ibid, 18.

164 Ibid.

165 Directive 2002/39/EC.

${ }^{166}$ Directive 97/67/EC, as amended by Directive 2002/39/EC, art 7(1). The market was opened in four steps. The first reduction of the reserved areas took place in 1999 when the market was opened for items weighing 350 grams or more and costing less than five times the public tariff. The Second Postal Directive reduced the limit for reserved services further to items weighing less than 100 grams as from 1 January 2003 and for services weighing less than 50 grams from 2006 on respectively.

167 Directive 97/67/EC, as amended by Directive 2002/39/EC, art 7(3).
} 

detailed "prospective study" of the implications of full market opening on universal service. ${ }^{168}$ Published in 2006, the study had one core message: that market opening should not be delayed beyond 2009. ${ }^{169}$ Those countries which had already introduced significant postal competition Sweden, Finland and the UK - had not seen a decline in the attainment or quality of USOs, and there was evidence of increased efficiency and reliability of postal services in those countries. ${ }^{170}$ Indeed, the Commission opined, one of the key problems in delaying full market opening would be the resulting lack of incentives operating on the incumbents to increase their efficiency and preparedness for fully fledged competition. Overall, the Commission's premise was that competition would enhance service quality, with universal service benefiting from the "dynamic efficiencies" that would be created. ${ }^{171}$ Only once this was achieved would further interventions be required to protect USOs. These would be regulatory safeguards, in the form of service standards or price caps and, only in the last resort, specific subsidies for USPs. ${ }^{172}$

The key recommendation of the Commission's study was implemented with the adoption in 2008 of the Third Postal Directive. ${ }^{173}$ All postal markets had to be fully opened to competition by the end of 2010, although eleven Member States took advantage of a two year transitional period. ${ }^{174}$

Despite the removal of the reserved areas, the scope of universal postal service has been retained substantially at the levels originally laid down in the First Postal Services Directive. ${ }^{175}$ Member States do retain a degree of discretion and flexibility to meet national demands and circumstances. ${ }^{176}$ While the first two Directives clearly envisaged the incumbent as the de facto universal service provider, alongside the removal of the reserved areas, the Third Postal

\footnotetext{
${ }^{168}$ Commission, "Report from the Commission to the European Parliament and the Council on the application of the Postal Directive (97/67/EC Directive as amended by Directive 2002/39/EC)" COM(2005) 102 final, 7.

169 Commission, "Prospective study on the impact on universal service of the full accomplishment of the postal internal market in 2009" (Report) COM(2006) 596 final.

${ }^{170}$ Commission, supra n 169, 4.

171 Ibid, 7.

172 Ibid.

173 Directive 2008/6/EC.

${ }^{174}$ Ibid, art 2(1) and art 3(1); Those Member States were Czech Republic, Greece, Cyprus, Latvia, Lithuania, Luxembourg, Hungary, Malta, Poland, Romania, and Slovakia.

175 Directive 97/67/EC, as amended by Directive 2002/39/EC, as amended by Directive 2008/6/EC, art 3.

176 Directive 2008/6/EC, Recital 23.
} 
Directive gives the Member States more freedom to designate one or more universal service provider(s), or to rely on the market when intervention is not necessary. ${ }^{177}$ The need to move beyond relying only upon the incumbent as the universal service provider is reflected in the Third Postal Services Directive which now encourages the use of public procurement procedures in the funding of universal services. ${ }^{178}$

\subsection{How changes in demand / the abolition of the reserved market has led to increased tensions on postal services - the UK and Germany}

Despite the Commission's position, sustained for over two decades, that liberalisation and universal service could both be pursued successfully in tandem, this view has come under stress in recent years. The logic underpinning the reserved areas approach was that the incumbent would retain an ability to cross-subsidise the non-profitable elements of its service from the profitable ones. While the potential to do so was progressively lowered with the reduction in the scope of reserved areas, full liberalisation has left incumbents facing 'cherry-picking' by new entrant firms across all of their activities. New entrants have chosen selective entry, mainly offering their services in urban areas with a focus on the business to business market. They can also freely choose the quantity and quality of their collections and deliveries, not being subject to the USO requirements. In many rural and less populated areas, the former incumbent is still the only service provider, with the "final mile" of delivery remaining a natural monopoly. Incumbents then are forced to lower prices where they face new entry, and raise prices where they do not, undermining the sustainability of universal service, at least in the long-term.

One solution to this problem, of course, is to extend USOs to new entrants. However, doing so especially in the early days of liberalisation, may well have created significant barriers to entry and hinder competition. The same could be said, albeit to a lesser extent, of requiring new entrants to contribute to an incumbent's net costs via a compensation mechanism. Another

\footnotetext{
${ }^{177}$ Ibid.

${ }^{178}$ Directive 97/67/EC, as amended by Directive 2008/6/EC, art 7(2).
} 
alternative is to reduce the scope of universal service (subject, of course, to the minimum requirements of the PSD). This has been done in a number of EU countries. ${ }^{179}$

In order to explore some of these issues further, we focus on recent developments in two Member States, Germany and the UK. These two countries were in the vanguard of opening their postal service markets to competition, well ahead of the 2010 deadline. ${ }^{180}$ The issue of the sustainability of universal service has come to the fore in both, with pressure from incumbents to reduce the scope of universal service. ${ }^{181}$

Currently in the UK, universal service obligations are only imposed on the incumbent, Royal Mail, and there is no compensation mechanism in place. In areas which an entrant does not wish to serve, it can choose instead downstream access, i.e., handing their postal items over to Royal Mail for final mile delivery. In Germany, Deutsche Post was designated as USP, but since the introduction of competition in 2008, its designation was removed, and no universal service provider is now designated. If universal service cannot be fulfilled by the market, then all licensed operators must provide the service jointly. ${ }^{182}$

\footnotetext{
${ }^{179}$ The frequency of delivery has been reduced to five days a week in the Netherlands and Italy. European Regulators Group for Postal Services, "Discussion paper on the implementation of Universal Service in the postal sector and the effects of recent changes in some countries on the scope of the USO" ERGP(14)16, 8 http://ec.europa.eu/internal_market/ergp/docs/documentation/2014/ergp-14-16-uso_en.pdf accessed 3 August 2016; PostNL, "General Conditions for the Universal Postal Service 2014", Article 20(1), file://ueahome/eresssf4/zgr08szu/data/Documents/general-conditions-universal-postal-service_tcm19-76269.pdf accessed 3 August 2016.

${ }^{180}$ The UK and German postal services markets were fully liberalised in 2006 and 2008 respectively. S Hough and L Booth, "Postal Services: Royal Mail plc" (2014) House of Commons, Standard Note, SN/EP/06763; Section 51(1) of the Postgesetz of 22 December 1997, BGBl. I, 3294, as amended by Art. 4 Abs. 106 G v. 7.8.2013, BGBl. I, 3154 .

${ }^{181}$ Both countries impose obligations which go further than is required by the PSD. The Postal Services Directive only requires the collection and delivery of letters and parcels from Mondays to Fridays, whereas in the UK and Germany letters are collected and delivered six days a week (Mondays to Saturdays) and in Germany the six days a week collection and delivery applies also for parcels. For a summary of USOs at European level, in Germany and the UK, see Harker at al., supra n 1, 35-38.

${ }^{182}$ If the German regulatory authority believes that the level of discharging universal service is not satisfactory, then all operators who have a licence, subject to a turnover threshold of 500,000 euros in the preceding calendar year, jointly provide universal postal service (section 12(1) of the Postgesetz of 22 December 1997, BGBl. I, 3294, as amended by Art. 4 Abs. 106 G v. 7.8.2013, BGBl. I, 3154). See C Feijoo and C Milne, "Re-thinking universal service policy for the digital era: setting the scene - an introduction to the special issue on universal service" (2008) 10, info 4.
} 
The levels of end-to-end competition (where the entrant collects, sorts and then distributes and delivers the mail) are low in the letter market as the vast majority of letters are still delivered by the former incumbent. ${ }^{183}$ In the UK, the most significant entrant was offering direct letter delivery in London, Liverpool and Manchester, but withdrew from the direct delivery market in 2015. ${ }^{184}$ However, despite an overall decline of letter volumes, the demand for downstream access has increased. ${ }^{185}$ In Germany, while there are hundreds of licensed operators, ${ }^{186}$ Deutsche Post delivers nearly 90 per cent of all (licensed) letters. ${ }^{187}$ In rural areas, consumers often do not have a choice between different providers and instead have to rely on the former incumbent. ${ }^{188}$ Downstream access also plays an important role in Germany. ${ }^{189}$

In both countries, the sustainability of universal service has been questioned. In the UK, Royal Mail regards itself as being at a competitive disadvantage compared with the other providers and has asked for a number of regulatory reviews of the USO scheme. In 2008, the Hooper Report acknowledged that universal service was under threat, mainly because of the declining letter market, but it also suggested that the incumbent was in a position to reduce its costs still further before any intervention was required. ${ }^{190}$ Two years later, in an update to the report, Hooper came

${ }^{183}$ In the UK, in 2013-14 only 0.6\% of letters by volume were delivered by providers other than Royal Mail, Ofcom, "Annual monitoring update on the postal market: Financial year 2013-14" (2014), paras 6.26-6.27, http://stakeholders.ofcom.org.uk/binaries/post/monitoring-reports/annual-monitoring-update-postal-2013-14.pdf accessed 3 August 2016

${ }^{184}$ BBC, "Royal Mail regulation to be reviewed by Ofcom" (16 June 2015), http://www.bbc.co.uk/news/business33145446 accessed 3 August 2016.

185 Ofcom, supra n 183, paras 6.20-6.23.

${ }^{186}$ At the end of 2013, there were about 600 licenced enterprises, many of them small or even micro businesses, Bundesnetzagentur, "Herausforderungen des Post-Universaldienstes Vorbereitung einer Stellungnahme gemäß § 47 Abs. 1 Satz 2 Postgesetz" (2014) Impulspapier, 2 http://www.bundesnetzagentur.de/SharedDocs/Downloads/DE/Sachgebiete/Post/Verbraucher/Universaldienst/Impul spapier.pdf?_blob=publicationFile\&v=1 accessed 3 August 2016.

${ }_{187}$ Bundesnetzagentur, "Marktuntersucherung Bericht über den lizenzpflichtigen Briefbereich 2015" (2016), 7, http://www.bundesnetzagentur.de/SharedDocs/Downloads/DE/Sachgebiete/Post/Unternehmen_Institutionen/Marktb eobachtung/LizenzpflichtigePDL/Marktuntersuchung2015.pdf?__blob=publicationFile\&v=5 accessed 3 August 2016.

${ }^{188}$ Monopolkommission, "Post 2013: Wettbewerbsschutz effectivieren" Sondergutachten 67, 27, http://www.monopolkommission.de/images/PDF/SG/s67_volltext.pdf accessed 3 August 2016.

${ }^{189}$ The majority of alternative postal provider carry out the entire service from collection to delivery of letters. Despite the fact that in 2012 more than $60 \%$ of all licensed letters carried out by the incumbents stemmed from downstream access, only a tenth of those products came from new entrants. Bundesnetzagentur, "Post 2012 /2013" (2013) Tätigkeitsbericht, http://www.bundesnetzagentur.de/SharedDocs/Downloads/DE/Allgemeines/Bundesnetzagentur/Publikationen/Beric hte/2013/131216_TaetigkeitsberichtPost2012.pdf?_blob=publicationFile\&v=3 3 August 2016.

${ }^{190}$ Richard Hooper, Deirdre Hutton and Smith Ian R, "Modernise or decline: Policies to maintain the universal postal service in the United Kingdom" (An independent review of the UK postal service sector, 2008), para 38, 
https://www.gov.uk/government/uploads/system/uploads/attachment_data/file/228786/7529.pdf accessed 3 August 2016.

${ }^{191}$ Richard Hooper, "Saving the Royal Mail's universal postal service in the digital age: An Update of the 2008 Independent Review of the Postal Services Sector" (September 2010) para 7

https://www.gov.uk/government/uploads/system/uploads/attachment_data/file/31808/10-1143-saving-royal-mailuniversal-postal-service.pdf accessed 3 August 2016.

${ }^{192}$ Ibid. Unlike the 2008 Report, the updated version concluded that the creation of a compensation fund should not be excluded per se, ibid, 40. For a discussion see L Booth and D Hough, "TNT Post and Royal mail: end-to-end competition in postal services" (2014) House of Commons Briefing Paper, http://researchbriefings.parliament.uk/ResearchBriefing/Summary/SN06935 accessed 3 August 2016.

${ }^{193}$ Ofcom, "Securing universal postal service" (2 December 2014), http://stakeholders.ofcom.org.uk/post/securinguniversal-postal-service/ accessed 3 August 2016; The regulator also argued that selective entry does not create a 'cherry-picking' situation, ibid. More recently the BIS Select Committee, in a report published in March 2015, reached the conclusion that alternative providers are able to 'cherry-pick' but the current level is too low to require any regulatory action, Business, Innovation and Skills Committee, supra n 153, para 39, http://www.publications.parliament.uk/pa/cm201415/cmselect/cmbis/769/769.pdf accessed 3 August 2016. Ofcom has recently confirmed the position: Ofcom "Review of the Regulation of

Royal Mail" (25 May 2016), http://stakeholders.ofcom.org.uk/binaries/consultations/royal-mail-

review/summary/Review-of-Royal-Mail-Regulation.pdf accessed 3 August 2016.

${ }^{194}$ Bundesnetzagentur, supra n 186, 2.

195 Ibid, 2-3. 
could be brought within it (perhaps by combining universal service in telecoms), while the scope of traditional letter services may need to be reduced, especially in rural and less populated areas. ${ }^{196}$ Given that the incumbent is not subject to any formal requirement with respect to universal service, it is not surprising that the situation in Germany is seen as more urgent than it is in the UK.

\subsection{Compensation mechanisms for universal service in postal services}

In postal services, it appears that while the majority of Member States have legislated for the establishment of a compensation fund, as of 2013, only four have actually gone on to establish one. ${ }^{197}$ A further four compensate the USPs directly from public funds. ${ }^{198}$ For those countries which have actively considered the introduction of compensation mechanisms, there is a wide variety of views on the pros and cons of their implementation from a competition perspective. The Swedish NRA is of the view that designation is vital to protect competition since the designation procedure triggers the requirement of the PSD on cost-related pricing. ${ }^{199}$ On the other hand, the Spanish competition authority has been highly critical of the designation of the incumbent as the USP for a fifteen year period, which it considers to be contrary to both the spirit and the letter of the PSD. ${ }^{200}$ This approach, however, appears to represent the practice in other Member States; in all cases where a USP has been designated it has been the incumbent firm, despite the Third Postal Directive encouraging some level of contestability. ${ }^{201}$ It also appears that, subject to limited exceptions, the vast majority of users in Member States will have service levels which meet the minimum USO requirements of the Directive without the need for intervention. $^{202}$

\footnotetext{
196 Ibid, 5-6.

197 Dieke et al., supra n 83, 154.

198 Ibid. As of 2013, 22 have legislated for a compensation fund, while six have deemed that the USO represents an unfair burden on the USP. Ibid.

199 Ibid, 133.

${ }^{200}$ Comision Nacional de la Competencia, The new regulatory framework for the traditional postal sector in Spain (March 2011), cited in Dieke et al., supra n 83, 133.

${ }^{201}$ Dieke et al., supra n 83, 16.

202 This is the result of a survey of Member States which concludes that "the risk of persons lacking basic universal service appears to be confined to relatively small populations living in thinly populated rural areas”, ibid, 136.
} 
State aid fulfils a different role in postal services compared to broadband. In broadband, state aid is used to increase access to a service, whereas in postal services it is used to maintain the current level of services and secure a level-playing field between undertakings that provide USOs and alternative operators with no such obligation. State aid cases are relatively few. There have only been 27 State aid decisions concerning compensation for discharging SGEI in the postal sector between 2003 and 2014. ${ }^{203}$ All of the cases concerned compensation payments to the former incumbent and the majority of cases involved aid granted for the provision of services that go beyond the minimum objectives and conditions set out by the PSD. ${ }^{204}$

There are only a handful of State aid cases that concern only the funding of USOs as defined in the PSD. ${ }^{205}$ In both decisions, the subsidy granted by the Italian government to the incumbent, Poste Italiane, was held to be State aid as the fourth Altmark criterion had not been satisfied. There are a number of other cases where Member States have been found to be subsidising services which include but go beyond the definition of USO in the PSD. ${ }^{206}$ Although these may be capable of being disaggregated for the purposes of a State aid assessment, Member States are unlikely to set-up a separate compensation scheme under the PSD, with all of the administrative and bureaucratic architecture that implies, if there are other subsidies which have to be notified to the Commission. Of course, this has the effect in practice of excluding new entrants from fulfilling the USOs. Where compensation mechanisms are used, the Commission guards against market distortionary effects. For example, in a recent State aid decision concerning the Greek postal incumbent, ELTA, the Commission had to assess a compensation fund based on contributions by the incumbent's competitors. ${ }^{207}$ The Commission concluded the compensation

\footnotetext{
${ }^{203}$ The cases were collected from the European Commission with the help of the EC's internal search engine $<$ http://ec.europa.eu/competition/elojade/isef/index.cfm>. The search focussed on cases for the economic sector "H.53 - Postal and courier activities" between 25.07.2003 (after Altmark) and 31.12.2014. The search was further refined by limiting the cases to compensation payments for the provision of SGEI. State aid decisions that concern subsidies paid to cover pension costs were excluded. Other cases not listed as a result of the online search but we became aware of through a review of the relevant literature so that 25 cases are part of the case law assessment. ${ }^{204}$ Services of General Economic Interest in postal services are, for example, the distribution of periodicals, the provision of basic financial services, the distribution of electoral material, and in some Member States even the payment of pensions. See, Competition Policy Brief, "High quality and competitive postal services for citizens and businesses - State aid control in the postal sector" (May 2014), 2 http://ec.europa.eu/competition/publications/cpb/2014/006_en.pdf accessed 3 August 2016. ${ }^{205}$ Decision NN51/2006 [2006] Poste Italiane SpA and Decision NN24/2008 [2008] Poste Italiane SpA. ${ }^{206}$ N462/2008 [2008] Poland; N312/2010 [2010] Poland; SA. 33989 [2012] Italy; SA.17653 [2013] Germany. ${ }^{207}$ Decision SA.35608 [2014] Hellenic Post (ELTA).
} 
scheme was incompatible as it appeared to place a disproportionate burden on new entrants, requiring them to make a contribution of up to 10 per cent of their turnover, thereby creating barriers to entry or even forcing them to exit the market. ${ }^{208}$

\subsection{Conclusions}

The findings of our case study suggest that the compensation mechanisms in the PSD have not been widely used. In many Member States, the incumbent provides services that go beyond the minimum requirement of universal postal service, but then struggles to finance those services, relying on state subsidies to maintain historic service levels. In those countries, such as the UK and Germany, where liberalisation has advanced significantly, incumbents have argued that universal service is unsustainable given the ability of new entrants to 'cherry-pick' the most profitable customers. Such arguments are likely to gain traction as demand for letter collection and delivery declines in the future.

\section{E. Conclusions}

In this paper we have considered the protection of universal service in the network industries, with a focus on telecommunications and postal services.

As has been observed in the literature, the protection of universal service was essentially a quid pro quo for liberalisation of the network industries. The EU sectoral legislation represented a compromise between these competing values; it sought to give formal legal protection to USOs and, in anticipation of full liberalisation and the eventual reduction of incumbents' market shares, put in place detailed and elaborate mechanisms for compensating the costs of serving disadvantaged and unprofitable consumers. As we have demonstrated, to a surprising degree, these provisions have remained dormant. Where they have been tested, they have demonstrated themselves to be particularly complex and cumbersome. The substantive rules, as interpreted by the Court and the Commission, have been framed primarily to promote contestability in the

\footnotetext{
${ }^{208}$ Ibid, para 193-194.
} 
provision of universal service and to avoid the danger of over-compensation to the USP (the incumbent in the vast majority of cases). It is difficult to avoid the conclusion that the limited use of compensation mechanisms is due in no small part to the complexity of the underlying sectoral rules.

Another surprising finding in this paper is the degree to which the State aid regime has been used as an alternative mechanism for funding USOs. ${ }^{209}$ Indeed, with respect to the public funding of investment in broadband infrastructure, this appears to be the result of a deliberate policy decision on the part of the Member States, albeit with a strong steer from the Commission. There is nothing new or novel in the use of the general competition rules as an alternative to sectoral regulatory tools. ${ }^{210}$ The more pertinent and interesting question from our point of view is why Member States would prefer to channel compensation schemes for approval under the State aid regime, rather than relying upon the detailed procedural and substantive rules contained in the Directives. It is difficult to avoid the conclusion that the State aid regime is preferred because of its flexibility, and the legal certainty resulting from the Commission's ex ante role in scrutinising the Member States' interventions in these markets.

State aid rules are not unproblematic. As a judge of the CJEU, Thomas von Danwitz, has observed, the State aid rules are not necessarily an appropriate tool in this context: "we have to acknowledge that state aid control is not a generally usable, unconditioned instrument of regulatory policy for realising a level playing field in liberalised markets. State aid control is rather focused on the use and abuse of state resources in a competitive environment". 211

Under the State aid rules, the Commission has substantial control over Member States' autonomy when it comes to protecting and promoting universal service. Where an EU norm exists in

\footnotetext{
${ }^{209}$ The Commission takes the rather surprising view that compensation payments for the provision of USOs through a compensation fund set up under the PSD is State aid and, therefore, assesses the compatibility under the State aid regime (Hellenic Post, supra n 207). We disagree with this approach.

${ }^{210}$ For a detailed discussion see M Harker, "EU Competition Law as a Tool for Dealing with Regulatory Failure: The Broadband Margin Squeeze Cases" (2013) Journal of Business Law 817; N Dunne, "Margin Squeeze: From Broken Regulation to Legal Uncertainty" (2011) 70 Cambridge Law Journal 34; D Geradin and R O'Donoghue, "The Concurrent Application of Competition Law and Regulation: The Case of Margin Squeeze in the Telecommunications Sector" (2005) 1 Journal of Competition Law and Economics 355. ${ }^{211}$ von Danwitz, supra n 23, 12.
} 
secondary legislation (as in the case of both the USD and PSD), Member States retain some measure of discretion to go beyond that norm, but a stricter test of proportionality obtains, requiring Member States demonstrate that the State aid measure is the least restrictive means of achieving the objective in question. ${ }^{212}$ Furthermore, the Commission has sought to limit the discretion that Member States enjoy in the design of compensation mechanisms, maximising the boundaries of its supervisory powers by its restrictive interpretation of the Altmark criteria and Article 106(2).

Controlling Member States' autonomy when intervening in markets is not the same task as regulating to ensure that the aims and objectives of regulation are being fulfilled. As we explained, the State aid rules, as they are now to be interpreted under the 2012 SGEI package, have been realigned to promote contestability in public service provision. Nevertheless, the public procurement requirement introduced by the SGEI Framework is by no means a panacea. While the intention is to encourage more contestability in the provision of SGEI, it may be that tendering does not result in the best outcomes. ${ }^{213}$ Asymmetries of information may have the effect that the winning bidder actually puts forward a bid which is too low to recover the costs of universal service. Furthermore, procurement procedures cannot prevent undertakings colluding in order to achieve higher compensation payments. And even though an incumbent may be able to offer to fulfil USOs at the lowest cost, it will have an incentive to bid-up its price as the costs of its competitors will in general be higher. There are also potential problems when it comes to specifying and securing service levels as there are incentives on bidders to compete purely on price rather than quality of service. ${ }^{214}$ While using a tendering process obviates the need for Member States to engage in the complex requirements under the Directives, reliance solely on the EU public procurement rules is not an effective substitute for regulation; they do not involve an effective ex post check on the accounts of the incumbent to avoid any over-compensation. ${ }^{215}$

\footnotetext{
212 Sauter, supra n 15, 180-81; see also Ross, supra n 67, 136-8; Fiedziuk, supra n 23; Klasse, supra n 35, 50-51.

${ }^{213}$ N Fiedziuk, "Putting services of general economic interest up for tender: reflections on applicable EU rules" (2013) 50 Common Market Law Review 87, 93.

${ }^{214}$ EAGCP, supra n 35, 6-7.

${ }^{215}$ Ibid, 6; Klasse, supra n 35, 46-47; Fiedziuk, supra n 213, 93-96.
} 
Furthermore, the State aid rules may not be engaged at all where the compensation payments are not capable of being imputable to the state. ${ }^{216}$

There will often be trade-offs between pursuing liberalisation policies while at the same time seeking to protect vulnerable and disadvantaged consumers from some of the adverse consequences of competition. The core issue is whether these trade-offs are better made within a framework which seeks to give formal protection to specified levels of universal service, while at the same time putting in place safeguards - procedural and substantive - aimed at minimising distortions of competition. There are a number of dangers, outlined above, in relying upon the State aid regime to control Member States' compensation of USOs. However, in our view, the key problem is that the State aid regime gives insufficient protection to the importance of universal service. The State aid rules are permissive; they do not require Member States to put in place mechanisms for compensation where the fulfilment of USOs require it. The danger is that such a discretionary approach to securing universal service will result in a diminution of USOs, leading to less protection for vulnerable and disadvantaged consumers. The Commission has been more concerned with ensuring that interventions in support of universal service do not produce disproportionate market distortions, that the incumbent is not over-compensated, and that new entrant firms are not excluded from being the USP. Very little, if any, attention has been paid to whether the USOs are in fact being fulfilled and, of equal importance, are being appropriately updated in the light of changing demand, technological and market conditions. It is difficult to avoid the conclusion that universal service, as a formal EU regulatory norm in the network industries, is in managed decline.

\footnotetext{
${ }^{216}$ On the problem of imputability see von Danwitz, supra n 23, 7-8. The extent to which an industry compensation scheme constitutes State aid is by no means straightforward. It depends upon whether the scheme is deemed to meet the cumulative conditions of being "aid granted by the State" and "through State resources". The latter condition may be particularly difficult to meet in cases where the contributions towards an industry compensation scheme are made only by private undertakings and are not redistributed via a public institution (see Case C-379/98 PreussenElecktra AG [2001] ECR I-2099). See M Clayton and M Catalan, "The Notion of State Resources: So Near and yet so Far" (2015) (2) European State Aid Law Quarterly 260 for a discussion of recent case law. It would appear vital that the scheme is both administered by a state institution and that there is state control over how the resources collected are distributed. However, the 2012 SGEI Communication posits that "compensatory payments for the operation of SGEIs which are financed through parafiscal charges or compulsory contributions imposed by the State and managed and apportioned in accordance with the provisions of the legislation are compensatory payments made through State resources." Commission, supra n 48, Recital 36.
} 